\title{
RUDOLF SCHLECHTER'S SOUTH-AMERICAN ORCHIDS III. SCHLECHTER'S “NETWORK”: NORTH AND NORTHEAST BRAZIL, THE GUIANAS
}

\author{
Carlos Ossenbach ${ }^{1,2,4} \&$ Rudolf Jenny ${ }^{3}$ \\ ${ }^{1}$ Jardín Botánico Lankester, Universidad de Costa Rica, P.O.Box 302-7050 Cartago, Costa Rica \\ ${ }^{2}$ Orquideario 25 de mayo, Sabanilla de Montes de Oca, San José, Costa Rica \\ ${ }^{3}$ Jany Renz Herbarium, Swiss Orchid Foundation, Switzerland \\ ${ }^{4}$ Corresponding author: caossenb1947@gmail.com
}

\begin{abstract}
AвSTRACT. The third chapter of the series about Rudolf Schlechter's South-American orchids presents concise biographical information about those botanists and orchid collectors who were related to Schlechter and worked in north and northeastern Brazil, as well as in the three Guianas. As an introduction, a brief geographical outline is presented, dividing the northern territories in four zones: the Amazon basin, the Araguaia-Tocantins river basin, the Northeast region and the Guianas. It is followed by a short mention of the historical milestones in the history of orchids in these regions during the preceding centuries.
\end{abstract}

KeY words: Amazon River, biography, Brazil Nordeste, history of botany, Orchidaceae, Roraima, Tocantins River

The Amazonas and Tocantins River basins, and the Northeast region. As we have read in the previous chapter, southern Brazil (taking the capital city of Brasilia as its northernmost point) is part of the La Plata River basin, which drains into the southern Atlantic Ocean (Ossenbach \& Jenny 2019: 207, fig. 11).

Northern and northwestern Brazil are part of the Amazon River basin, comprising the federal states of Roraima, Amapá, Amazonas, Pará, Acre, Rondônia and northern Matto Grosso (Fig. 1). Parts of Bolivia, Peru, Colombia, Ecuador, Venezuela and the southern part of the Guianas also drain into the Amazon River. The Amazon basin's immense territory covers over 50\% of the total area of Brazil, over one third of the South American continent. Many new orchid species were collected along the Amazon, and many were named after the legendary river, among them by Schlechter, Camaridium amazonicum (Fig. 2-3).

To the Southeast of the Amazon we find the much smaller basin of the Araguaia-Tocantins river system, with an area of approximately $10 \%$ of the Brazilian territory. The Tocantins flows into the Atlantic Ocean alongside the Amazonas. The mouth of the combined rivers forms a large estuary at the port city of Belém (Fig. 4). Part of the basin are the northern regions of the state of Goiás, and the states of Tocantins, western Maranhão and eastern Pará.
Finally we have the Brazilian states that form the coastline from Pará in the north to Espirito Santo in the south, namely eastern Maranhão, Piauí, Ceará, Rio Grande do Norte, Paraíba, Pernambuco, Alagoas, Sergipe, and Bahia, which occupy the rest of northern Brazil, some $15 \%$ of the country's territory (Fig. 5).

The Northeast region, better known as Nordeste in Brazil, was the first to be discovered and colonized by the Portuguese and other Europeans, playing a crucial role in the country's history. To our day, the Nordeste is recognized for its history and culture, as well as for its beautiful natural sights. It is also the point of entry into the Amazon, which exerted, since the early years of Portuguese colonization, an irresistible attraction on botanical explorers and adventurers. Botanical and zoological treasures lay hidden in the midst of immense tropical forests and along mighty rivers. From the early $17^{\text {th }}$ century to our day, a number of private or state-sponsored scientific expeditions into the Brazilian North must be regarded as milestones in the country's botanical history.

In 1637, the Dutchman Wilhem Piso (1611-1668) and the German Georg Marcgrave (1610-1644) set foot in Pernambuco, to take part in the exploration of the Northeast, under the patronage of Prince Johan Maurits van Nassau-Siegen from 1637 to 1644, Dutch administrator of the recently conquered "Dutch 


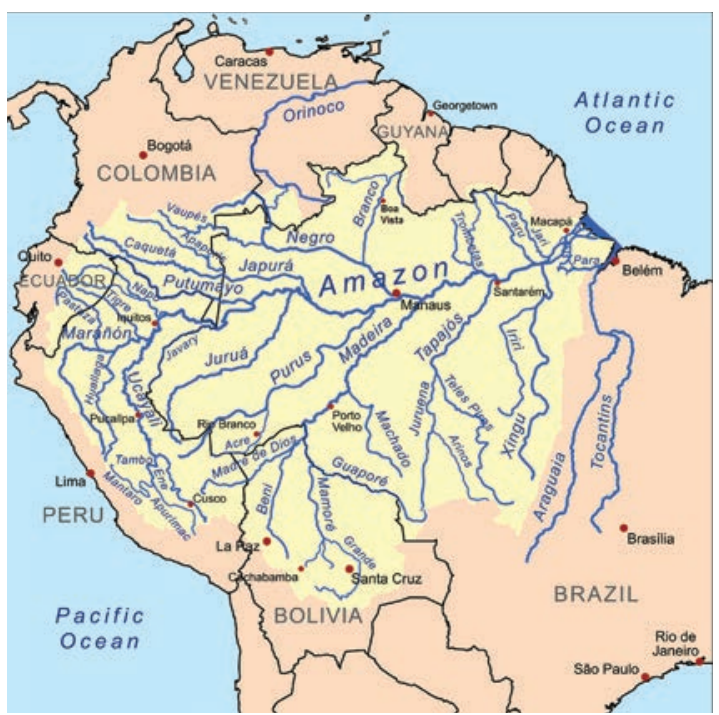

Figure 1. Map of the Amazon River basin. By Karl Musser.

Brazil". Together, they made extensive botanical and zoological collections in the province of Pernambuco. Piso was responsible for giving the genus Vanilla its present name and in Marcgrave's herbarium we find the first dried specimen of a tropical American orchid, Trigonidium acuminatum. Part of Nassau Siegen's

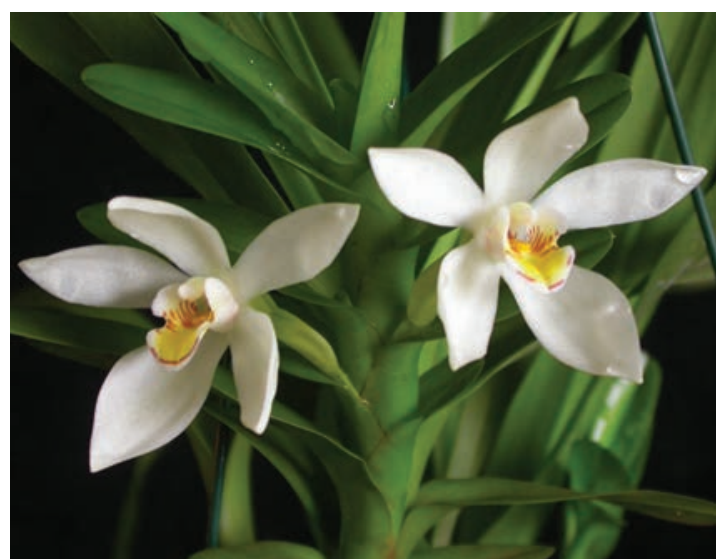

FiguRE 2. Camaridium amazonicum Schltr. (as Camaridium ochroleucum Lindl.) Photograph by Dalton Holland Baptista

entourage was the Dutch painter Frans Post, from whom a large number of paintings are kept, mainly with rural motives and landscapes of the province of Pernambuco (Fig. 6).

Charles de la Condamine who navigated the river in 1743, wrote the first biological report (de La Condamine 1745); his expedition is considered "the beginning of the great era of Amazonian travel by

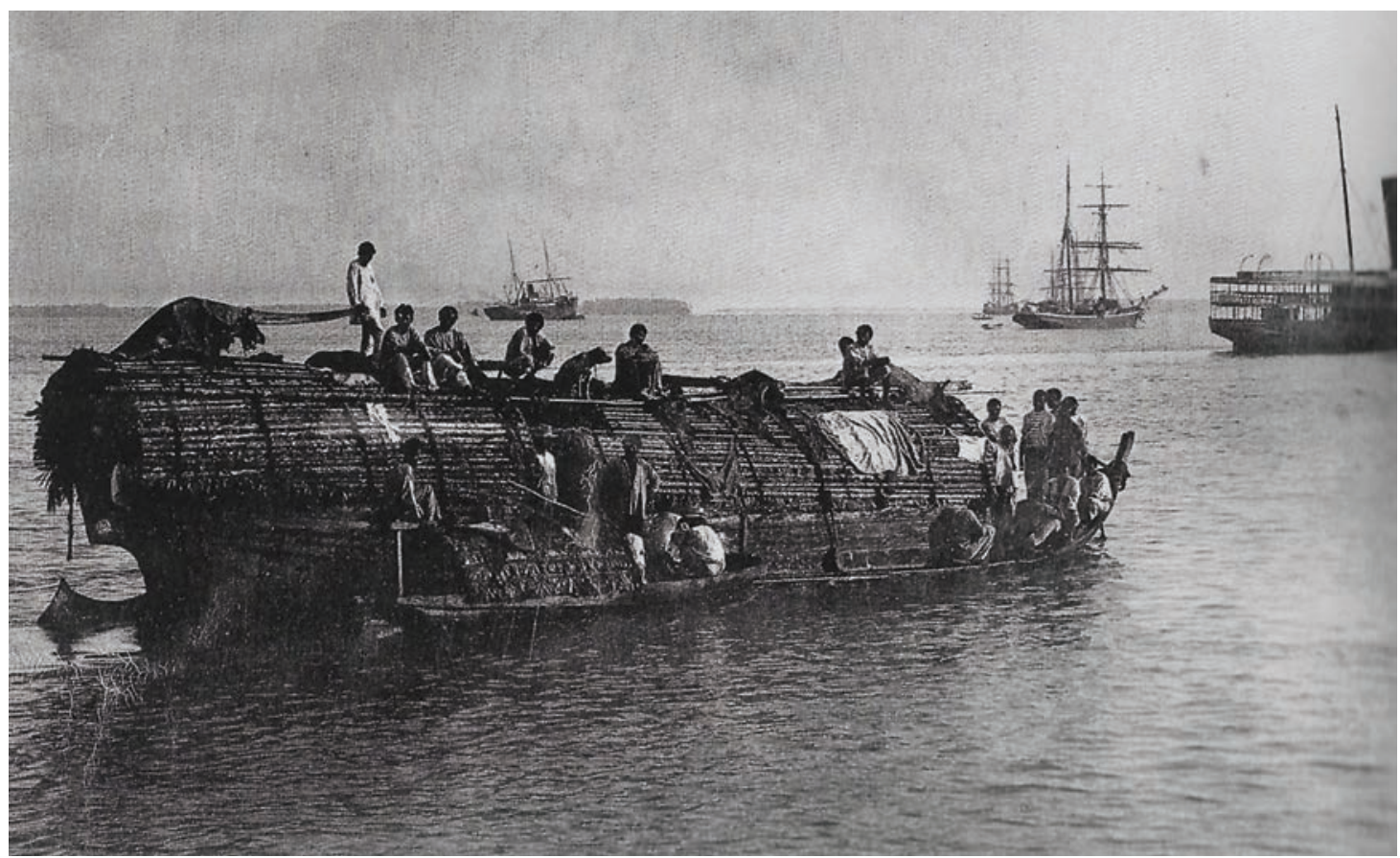

FIGURE 3. Canoe, steamship and sailships on the Amazon. Photograph by G.Huebner, ca. 1896-1910. In Schoepff 2005: plate 34. 


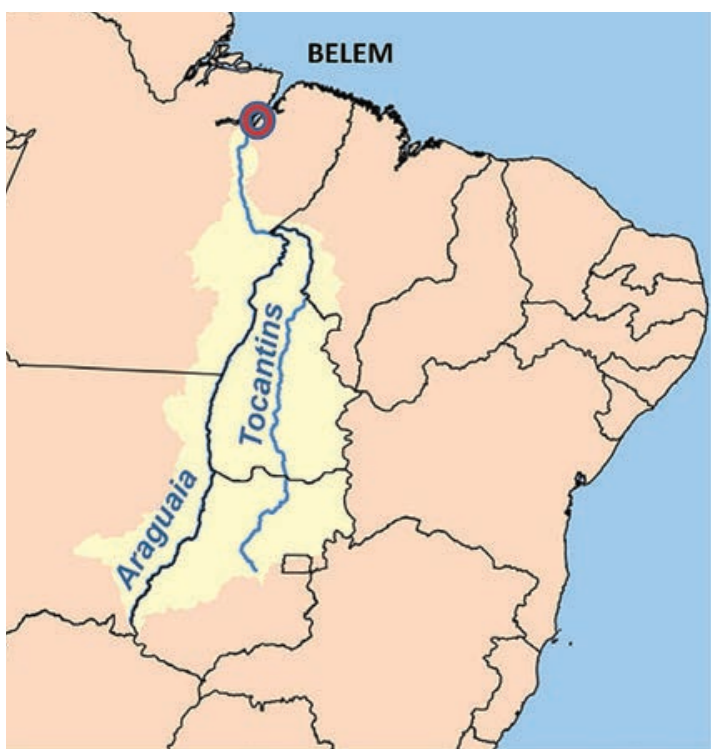

Figure 4. Map of the Araguaia-Tocantins river basin. By Karl Musser.

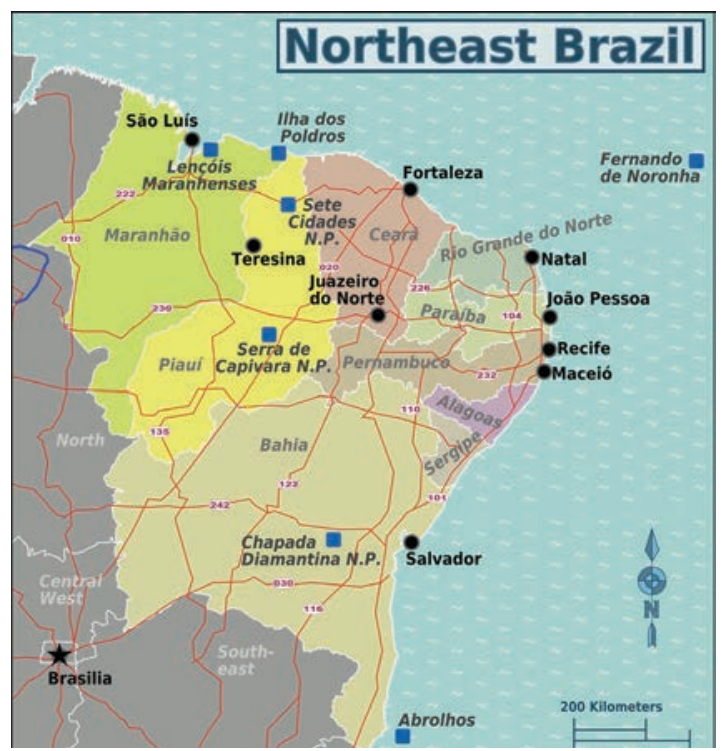

FIgURE 5. Map of Northeast Brazil. By Claus Hansen.

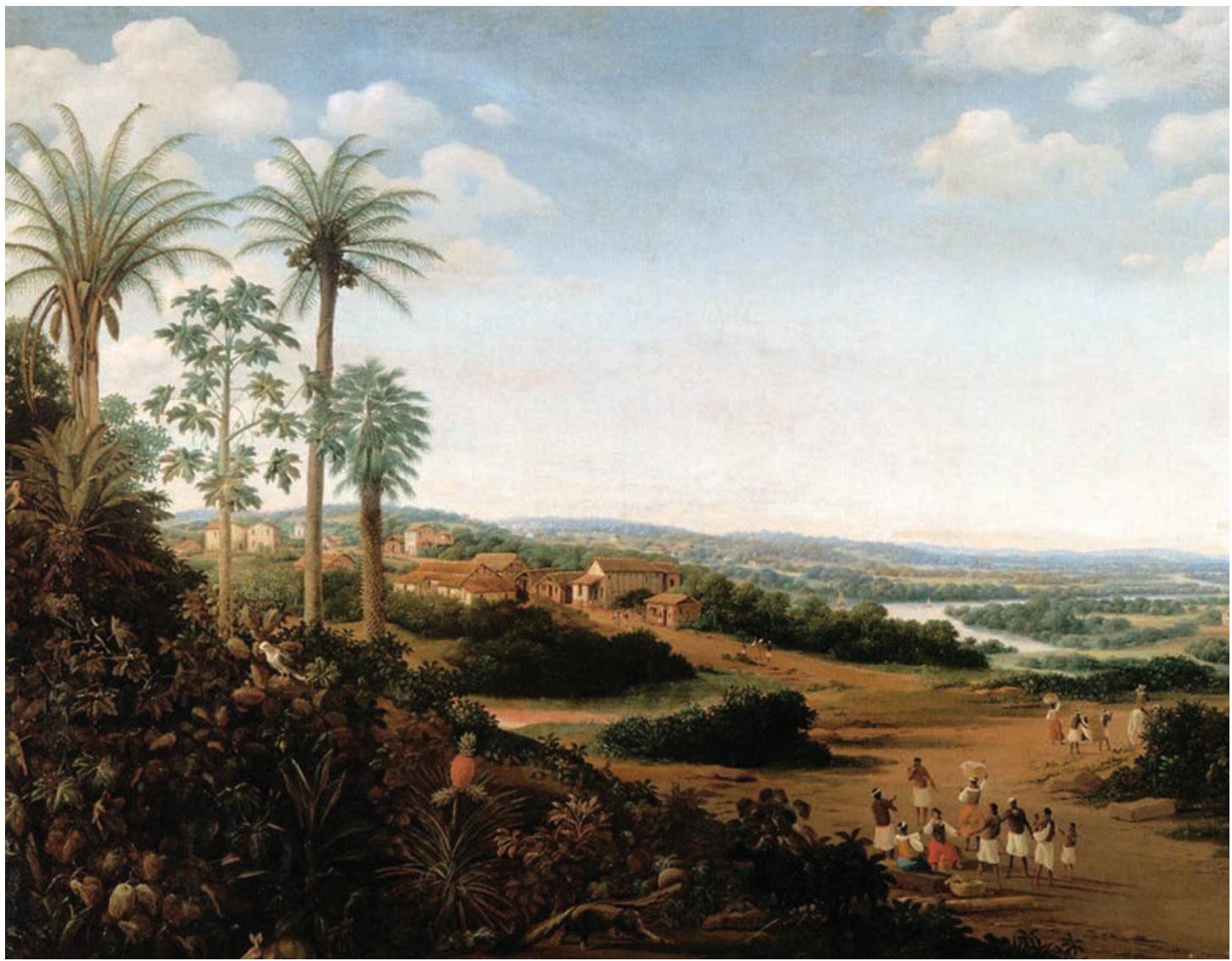

Figure 6. Pernambuco landscape. Oil on canvas by Frans Post. 


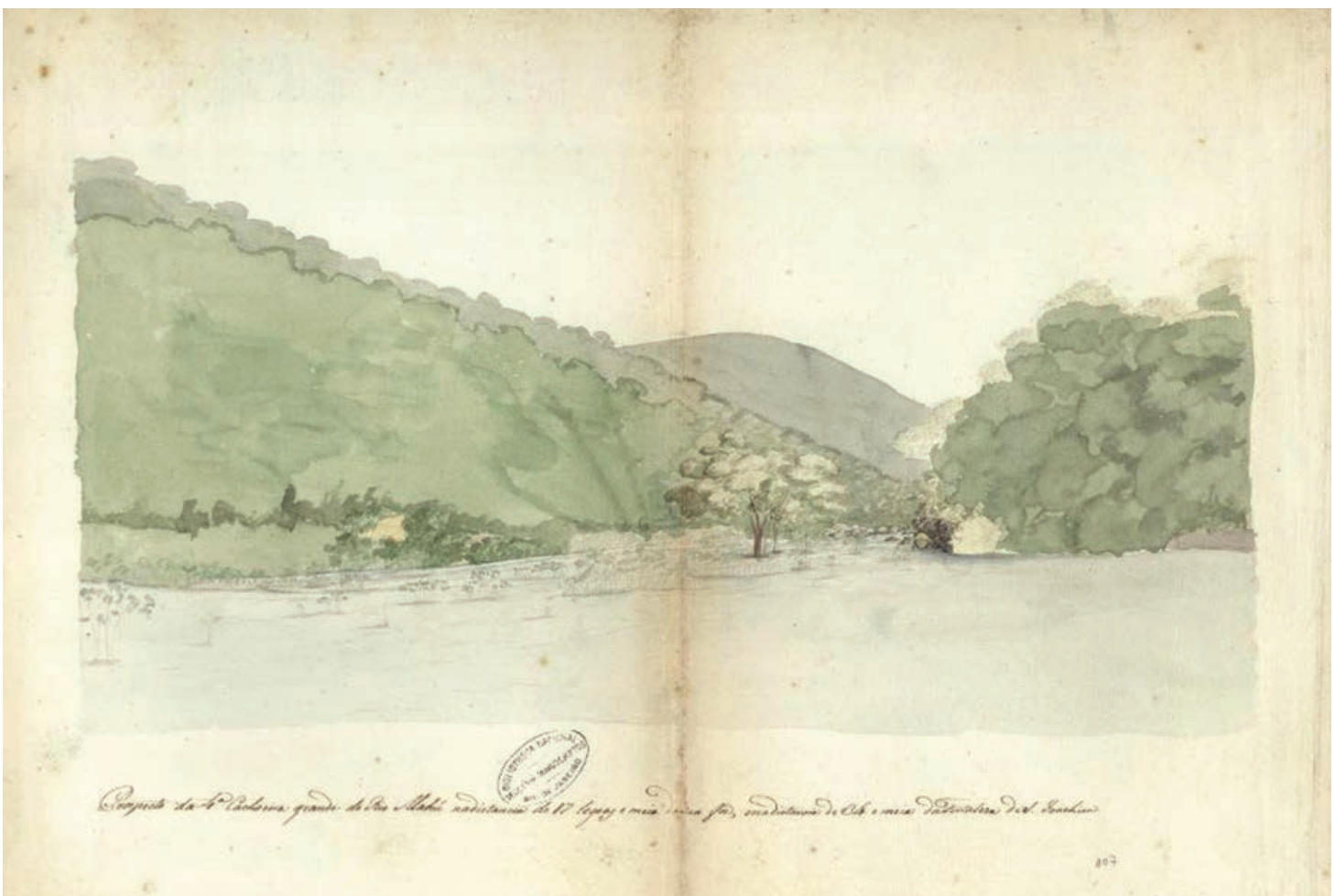

FIGURE 7. Waterfall on the Mahú River, near the border with Guiana. Watercolor by J. Codina. National Library, Rio de Janeiro.

European scientists" (ter Steege et al. 2016).

Twenty-five years later, Alexandre Rodrigues Ferreira (1756-1816) undertook his "philosophical journey" from 1783 to 1792 , exploring the length of the Amazon, navigating the Río Negro, and continuing to the village of Cuiabá, in the province of Matto Grosso. It was the first officially sponsored expedition, and had been organized by Domenico Vandelli, Director of the Ajuda Botanical Garden in Lisbon. Joaquim José Codina and José Joaquim Freire, the draftsmen of the expedition, left an important legacy of watercolors depicting ethnological objects, landscapes, as well as specimens of the flora and fauna of the region (Fig. 7-8). Large natural history collections were made during the expedition. Herbarium material, skillfully prepared stuffed animals and rich ethnographical collections were described in numerous memoirs and travel accounts. Much of this material is still extant. However, none of the results of the expedition were ever published, and a part of the collections disappeared during the looting that followed the French occupation of Portugal in 1808 (Ossenbach 2020: 269).

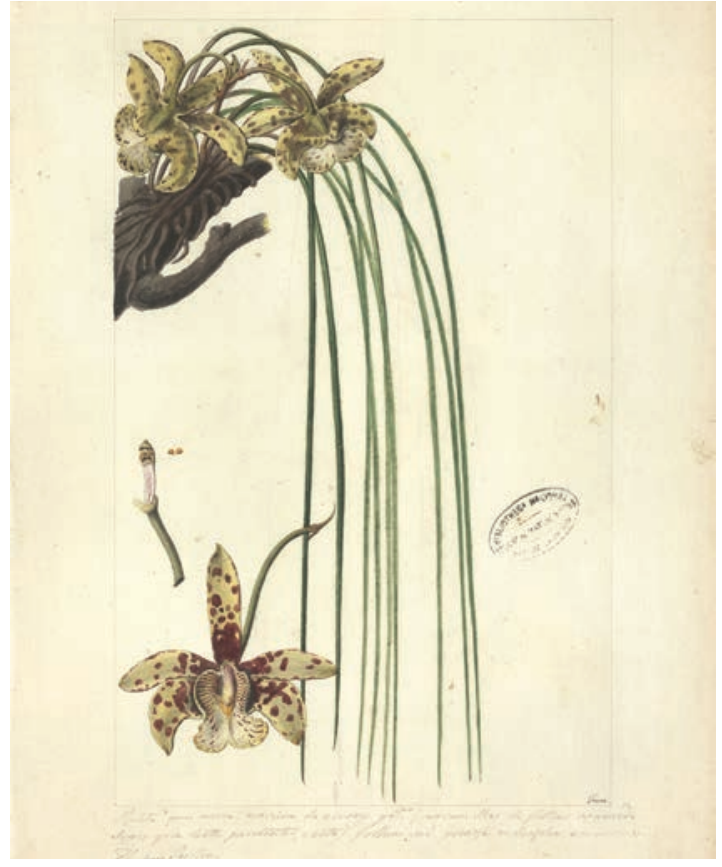

Figure 8. Scuticaria hadwenii (Lindl.) Planch. By José Joaquim Freire. National Library, Rio de Janeiro. 
The upper Río Negro River was explored by the famous naturalists F. H. A. von Humboldt and A. J. A. Bonpland in 1800. Again, a rich botanical harvest resulted from their expedition.

The arrival of Grigory Ivanovich, Baron of Langsdorff (1774-1852) in Rio de Janeiro in 1813 would mark the beginning of decades of an extensive exploration of Brazil by European naturalists. Langsdorff took advantage of the fact that in 1808 the Portuguese Court, at the time residing in Brazil, had opened the country's borders to foreign travelers and naturalists. In 1821, Langdorff proposed to the Alexander I and the Academy of Sciences of Saint Petersburg to lead an ambitious exploratory and scientific expedition from São Paulo to Pará, in the Amazon, via a fluvial route. It would result in the first extensive exploration of the Amazon basin and Brazil's Nordeste in modern times. After years of extensive preparations, the Langsdorff expedition departed with 40 people and 7 boats from Porto Feliz, by the Tietê river in June 1826 (Fig. 9) and reached Cuiabá, in Mato Grosso six months later, in January 1827. After almost unbearable hardships, among them the death by drowing of the expedition's young artist Aimé-Adrien Taunay, the expedition finally arrived at Belém in December 1828, having navigated a large part of the course of the Amazon.

From Belém, the expedition took ship to Rio de Janeiro, where they arrived in March 1829, almost three years and 6,000 kilometers after its departure. The expedition members were in pitiful conditions, and von Langsdorff showed signs of insanity during the last part of the journey.

A young Scot named George Gardner (1810-1849), a trained surgeon whose interest in botany had been stimulated by William Hooker's botany lectures at the University of Glasgow, sailed to Brazil looking for a better climate to improve his ill health and arrived in Río de Janeiro in 1836. Gardner then travelled to the North and Northeast of Brazil and spent the next five years making one of the most extensive collections of plants from the country then seen. It comprised about 6,000 numbers, representing approximately 3,000 species. Gardner's travels, after an initial excursion from Río de Janeiro to the Organ Mountains, took him to the provinces of Bahía, Pernambuco, Alagoas, Ceará, Piauí, Maranhão, and parts of Goias and Minas Gerais.
Carl Friedrich Philipp von Martius (1794-1868) and Johann Baptist von Spix (1781-1826) arrived in Brazil as part of the Austrian Scientific Expedition accompanying Archduchess Leopoldina. They explored northeastern Brazil and the course of the Amazon between 1817 and 1820. The botanical material collected during their journey served as the base for Martius' monumental Flora Brasiliensis, which he began publishing in 1840 . His work was continued by August Wilhelm Eichler and Ignatz Urban, and the last volume appeared in 1906.

From 1849 to $1864,1848-1952$ and $1848-1859$, respectively, Richard Spruce (1817-1892), Alfred Russell Wallace (1825-1892) and Henry Walter Bates (1825-1892) travelled to Brazil and navigated the major part of the Amazon and many of its tributaries. Spruce, an English botanist specializing in bryology, came to the attention of William Jackson Hooker, the director of the Royal Botanic Gardens at Kew. After a collecting expedition to the Pyrenees between 1845 and 1846, he was recommended for a much more challenging expedition to Brazil. Spruce landed in Pará in July 1849, and during the next 15 years travelled the Amazon from its mouth to the Andes of Peru.

While travelling the Amazon up to Santarém, he first met the two other naturalists who were, like himself, exploring the Amazon. Although they did not travel together, their paths crossed occasionally, always an opportunity to exchange information and specimens of natural history. Richard Spruce's Notes of a Botanist on the Amazon \& Andes (2014, edited by Wallace) and Henry Bates' The Naturalist on the River Amazon (1863) became classics in the travel literature of the Victorian Era (Fig. 10).

João Barbosa Rodrigues (1842-1909) was considered one of Brazil's greatest botanists, known especially for his work on orchids and palms. He dedicated a large part of his life to the direction of the Botanical Garden in Río, from 1890 to his death in 1909. He began his botanical expeditions in 1868 and was commissioned by the Brazilian government in 1871 to explore the Amazon basin and study palms. The expedition lasted until 1874, and during this time Rodrigues drew nearly 900 color plates of Brazilian orchids (Fig. 11-12). Because of difficulty financing a publication with illustrations, Rodrigues published 


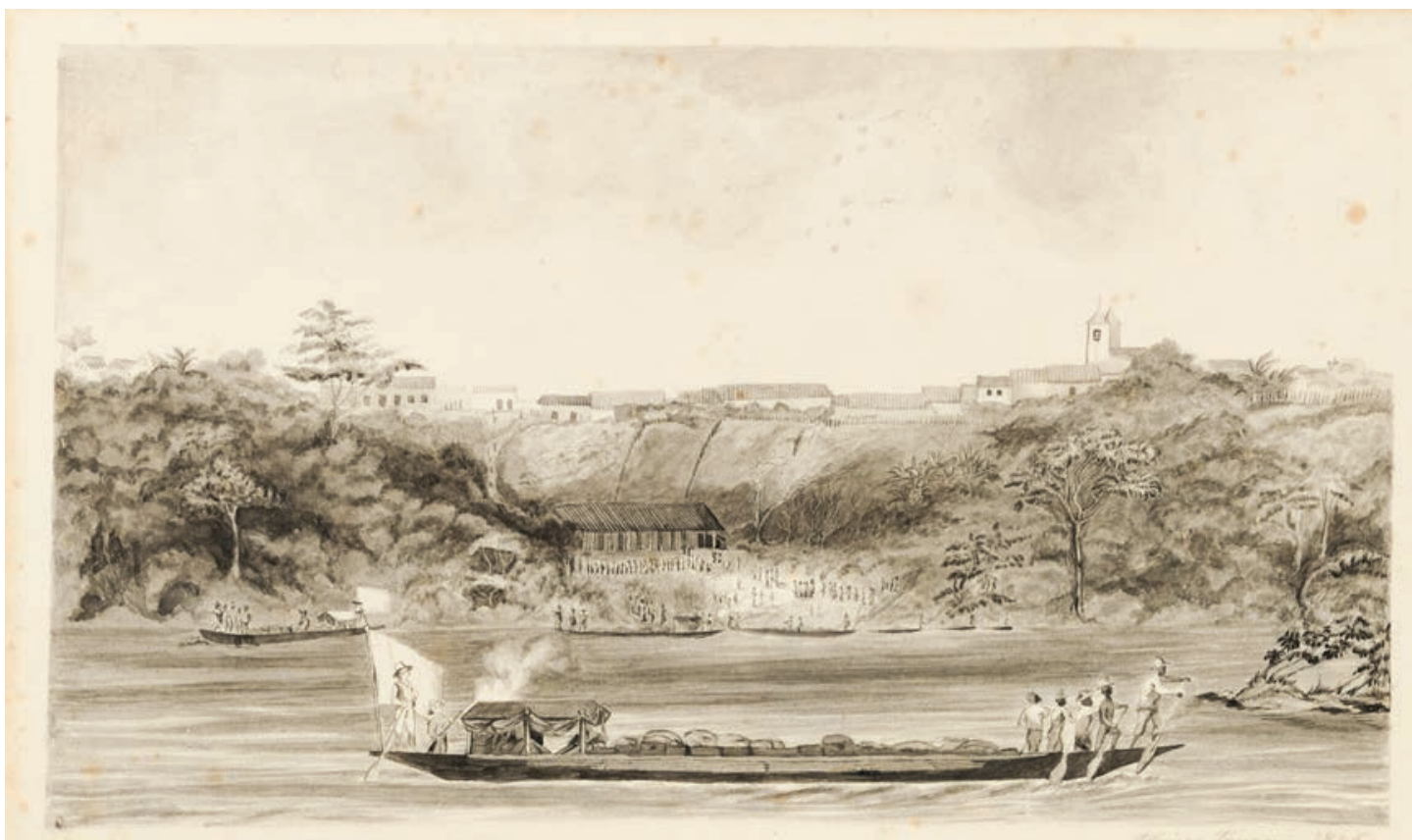

Figure 9. Departure of Langsdorff's expedition on the Tietê River, June of 1826. Watercolor by Aimé-Adrien Taunay.

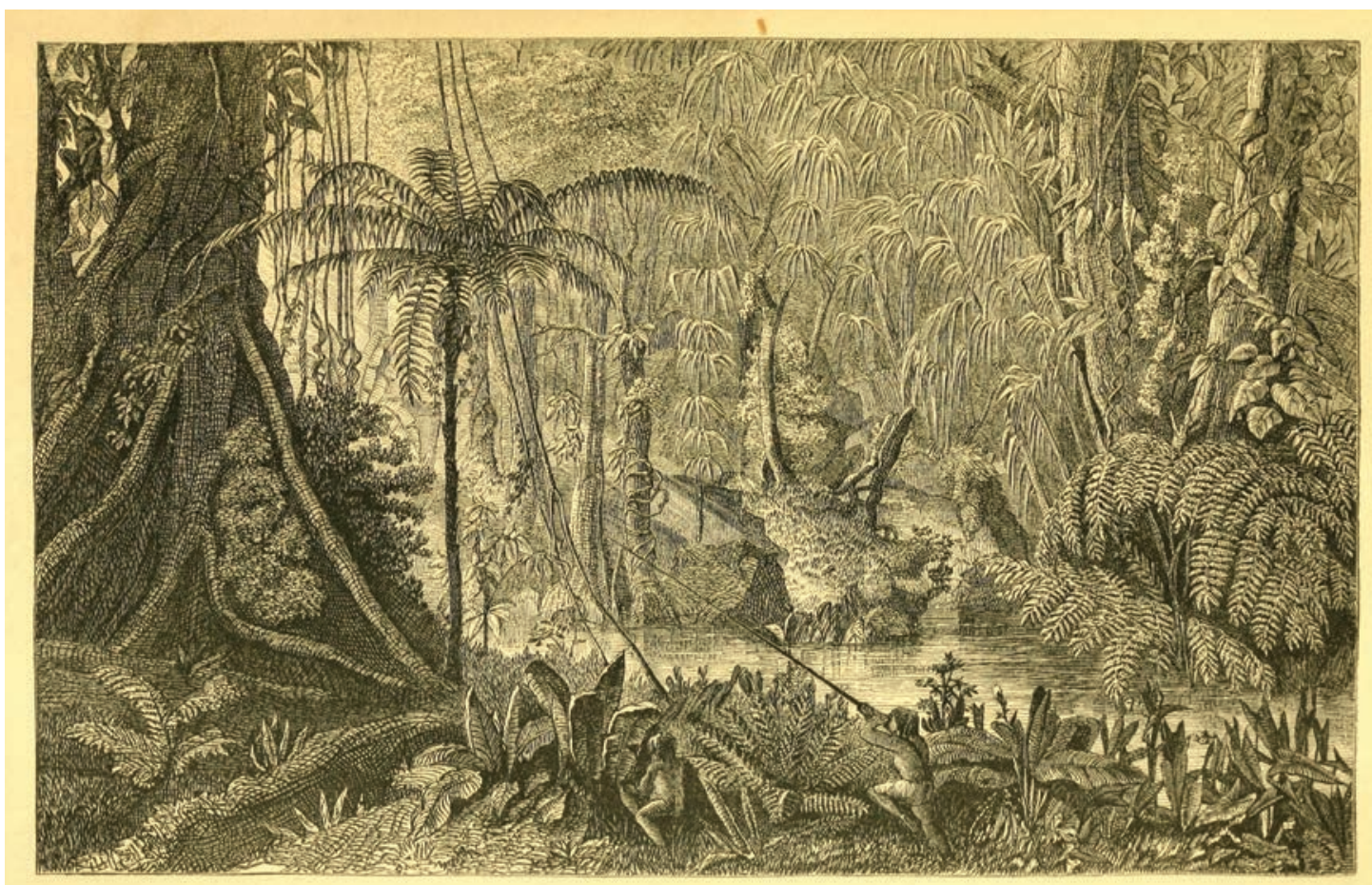

INTERIOR OF PRIMANAT, FOREST ON THE AMAZONS

Vol. I., page 72

FIGURE 10. Interior of primeval forest of the Amazon. In Bates, The Naturalist on the River Amazon (1863), plate 2. 


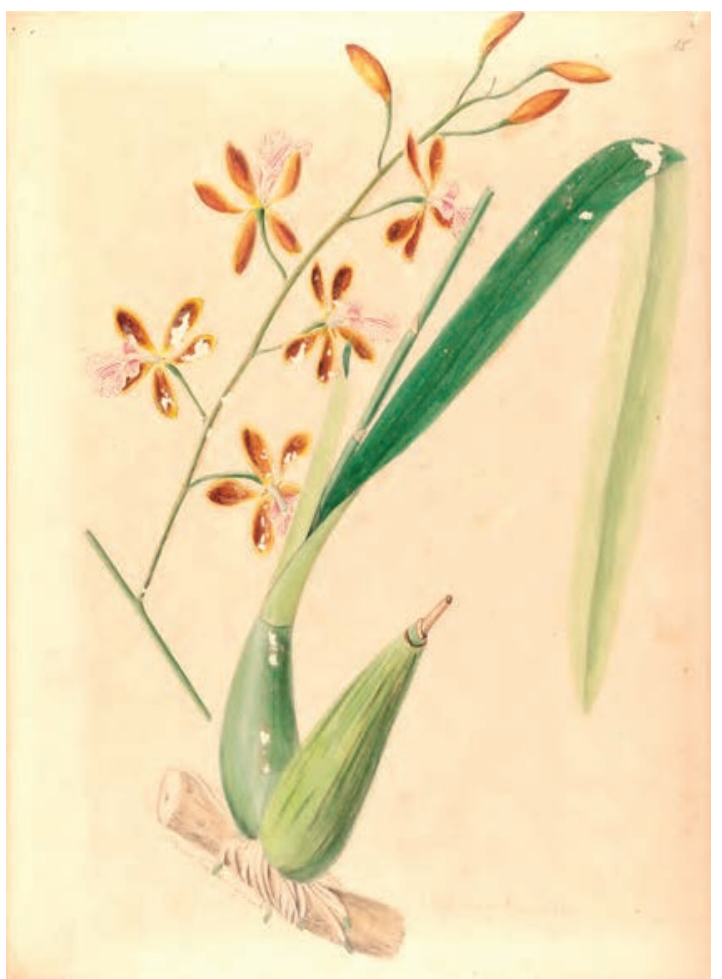

Figure 11. Encyclia megalantha Barb.Rodr. Barbosa Rodriguez, Iconographie des Orchidées du Brésil, vol. 4: plate 15 .

descriptions of more than 540 new orchids and 28 new genera without any images in his important twovolume work Genera et species orchidearum novarum (1877/1881).

The scientific exploration of northern Brazil in the $19^{\text {th }}$ century would end with the two expeditions organized by the German Herrmann Meyer (18711932) to the headwaters of the Xingú River in the plains of Matto Grosso. Meyer explored the region in 1896 and again in 1899. Although the scientific results were relatively meager, Meyer's expeditions are of utmost relevance to our story: they opened to Schlechter as we will see - the door to the splendorous world of tropical American orchids.

\section{Herrmann Meyer's expeditions to the Xingú River}

Born in Leipzig, Herrmann Meyer (1872-1932) (Fig. 13-14) studied anthropology and ethnology in Berlin and Jena. He travelled after his studies through the United States and slowly developed his plan to continue with the explorations of Central

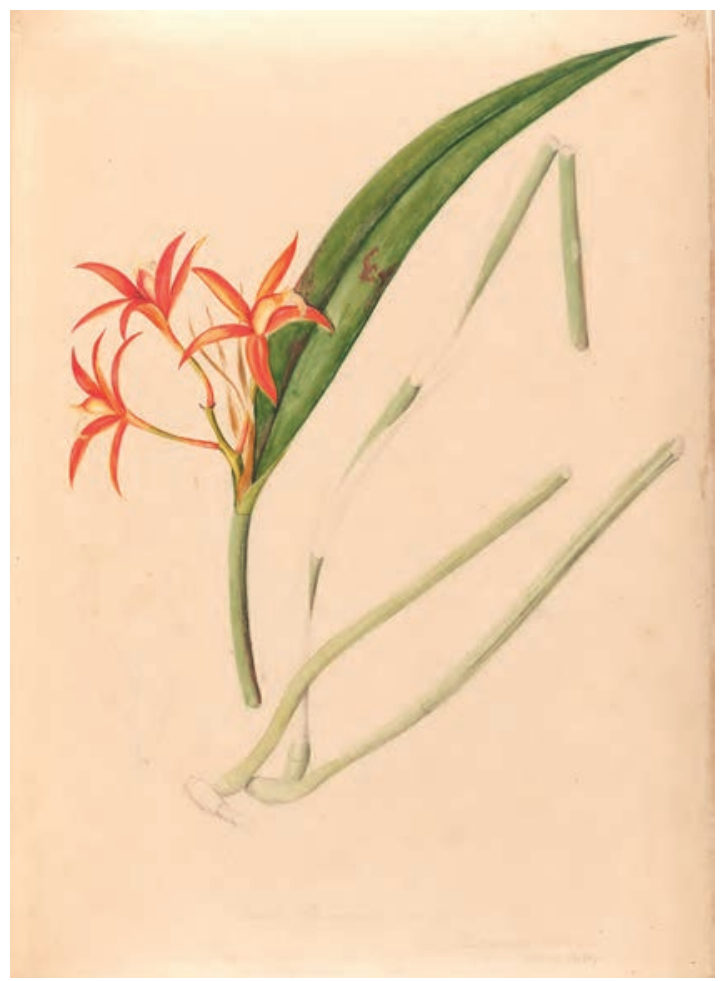

Figure 12. Laelia harpophorum Rchb.f. Barbosa Rodriguez, Iconographie des Orchidées du Brésil, vol. 4: plate 54.

Brazil by German ethnologist Karl von den Steinen (1855-1929). Von den Steinen had organized two expeditions, in 1884 and $1887-1888$ to the region of the Xingú River, one of the tributaries of the lower Amazon, in the province of Matto Grosso. Meyer was undoubtedly motivated by the successes of his brother Hans as explorer of Africa. Hans Meyer is credited with being the first European to reach the summit of Mount Kilimanjaro (5895 m), Africa's highest mountain (Brogiato 2019).

Hermann Meyer sailed in 1895 to Brazil in the company of the anthropologist Karl Ranke and the physician Heinrich Dahlen, the latter dying shortly after arrival in Rio on yellow fever. Before starting on the journey to the Mattogrosso, Meyer visited first the German colonies around Petropolis and Florianopolis, as well as Blumenau in Rio Grande do Sul. He convinced another German, an experienced explorer by the name of Carlos Dhein to take part in the expedition. Dhein had been one of the guides during von Steinen's expedition in 1884. 


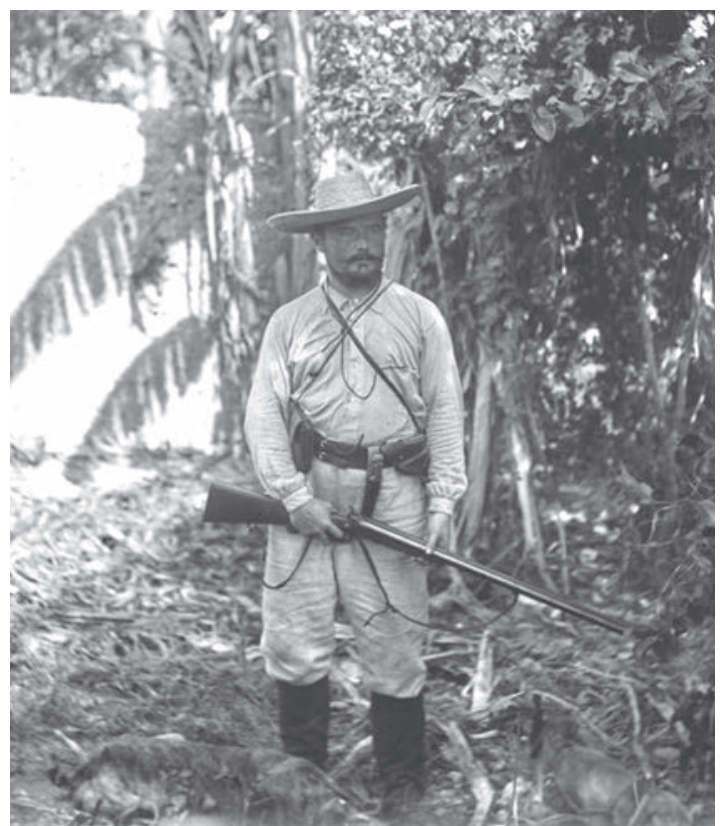

Figure 13. Herrmann Meyer in Cuiabá (Matto Grosso), 1896. Grassi Museum für Völkerkunde, Leipzig.
The expedition embarked to Buenos Aires in the first months of 1886 , and from there sailed on the Paraná and Paraguay Rivers to Cuiabá, the capital city of Matto Grosso (Fig. 13-14). With Cuiabá as headquarters, the group explored the region of the Upper Xingú during the next 6 months, returning then to Río de Janeiro from where Meyer sailed back to Germany.

After his return, Meyer worked for a short time as assistant at the Leipziger Ethnological Museum, but was again in Brazil in the summer of 1898 , this time in the company of the botanist Robert Pilger (1876-1923) and ethnologist Theodor Koch-Grünberg (1872-1924). In the spring of 1899, they navigated the rapids of the Río Ronuro, the largest tributary of the Xingú. After losing most of their provisions during an accident at a large waterfall, they continued on the Xingú until reaching the Amazon. The expedition was in a deplorable state, most of the equipment had been lost in accidents on the rivers, the group was weakened through hunger and fevers. Thus, it was decided to return, landing again in

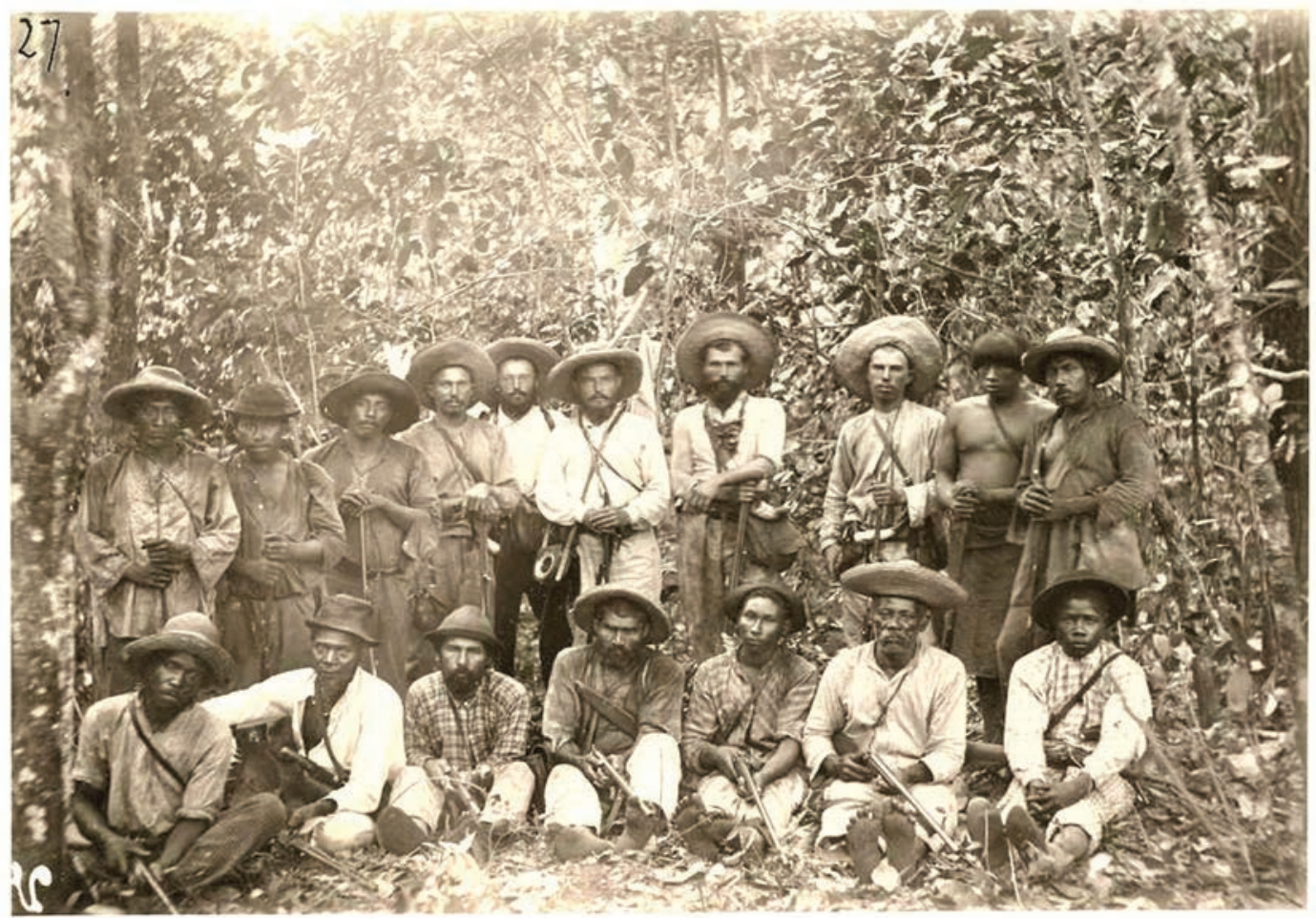

FiguRE 14. Herrmann Meyer (1871-1932) (center of back row, standing) in the Brazilian jungle during the first Xingú expedition, 1896. Grassi Museum für Völkerkunde, Leipzig. 
Buenos Aires in December 1899, and continuing across the Atlantic, before arriving in Germany in January of 1900. After his failure, Meyer abandoned his ambitious plans, turned his back to science and gave up his position at the Leipzig Museum, spending the rest of his life as director of the family business. The expected publication about the expedition never came to light (Koch-Grünberg 2004: 410). As already mentioned, the scientific results of the expedition were hardly worth the hardships. However, botanical collections were made, with over 3000 different species.

Herrmann Meyer, without success as an explorer, earned nevertheless a reputation as a founder of colonies of German immigrants in southern Brazil. During his visit to Rio Grande do Sul in 1898, before departing on his expedition, he went by train and then on horseback from Porto Alegre to the region of Cruz Alta, where Carlos Dhein had bought in his name, two years earlier, four large parcels of land. Meyer formed a company named Empresa de Colonização Dr. Herrmann Meyer and founded the German colony of Neu-Württemberg and two smaller colonies by the names of Xingú and Guaryta. Meyer's company was registered in 1898 in Porto Alegre, but its formal seat was the German city of Leipzig. Neu-Württemberg had in 1902 a population of nearly 3,000. The colony carries today the name of Panambí, and is a prosperous city with some 38,000 inhabitants.

Alfred Bornmüller (1868-1947) (Fig. 15), a cousin of Meyer, held the position of Director of the colony of Neu-Württemberg fom 1903 to 1907. He made ocasional botanical collections, among them a new orchid species, Capanemia australis (Kraenzl.) Schltr. (Fig. 16).

\section{Robert Knud Friedrich Pilger (1876-1953;} collected 1899)

Robert Knud Friedrich Pilger (1876-1953) (Fig. 17), botanist from the Berlin Botanical Garden, was part of Meyer's second Xingú expedition. At the young age of 22, Pilger was engaged in 1898 by Meyer to take part in his proposed adventure. He had been recommended by A. Engler, who had recognized Pilger's talent and knowledge (Melchior 1955: 294).

While Meyer travelled in the summer of 1898 to Río Grande do Sul, Pilger and Koch-Grünberg sailed early in 1899 to Buenos Aires, where they waited until Meyer's

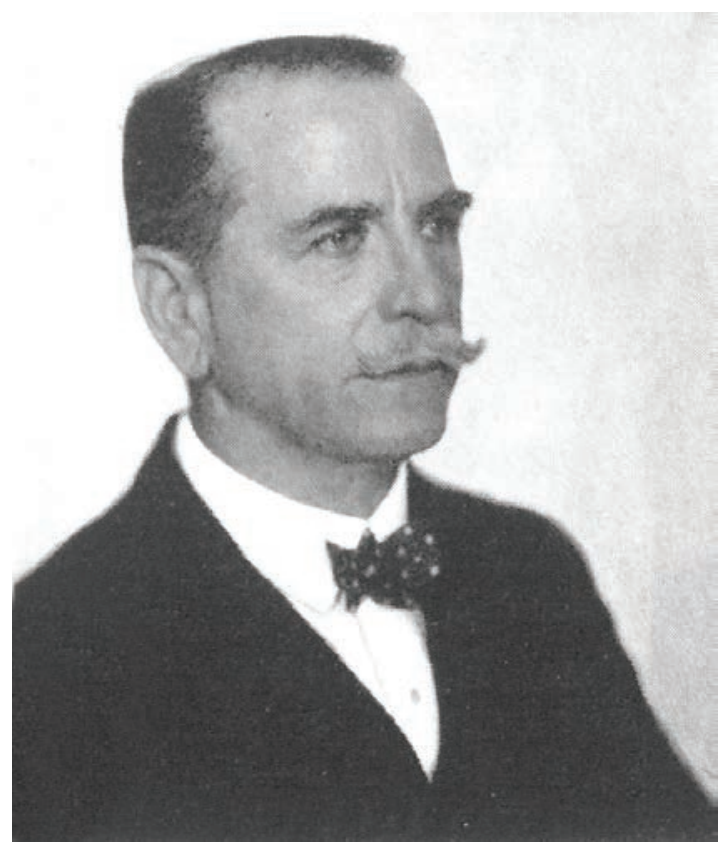

Figure 15. Alfred Bornmüller (1868-1947). Archives of Rudolf Jenny.

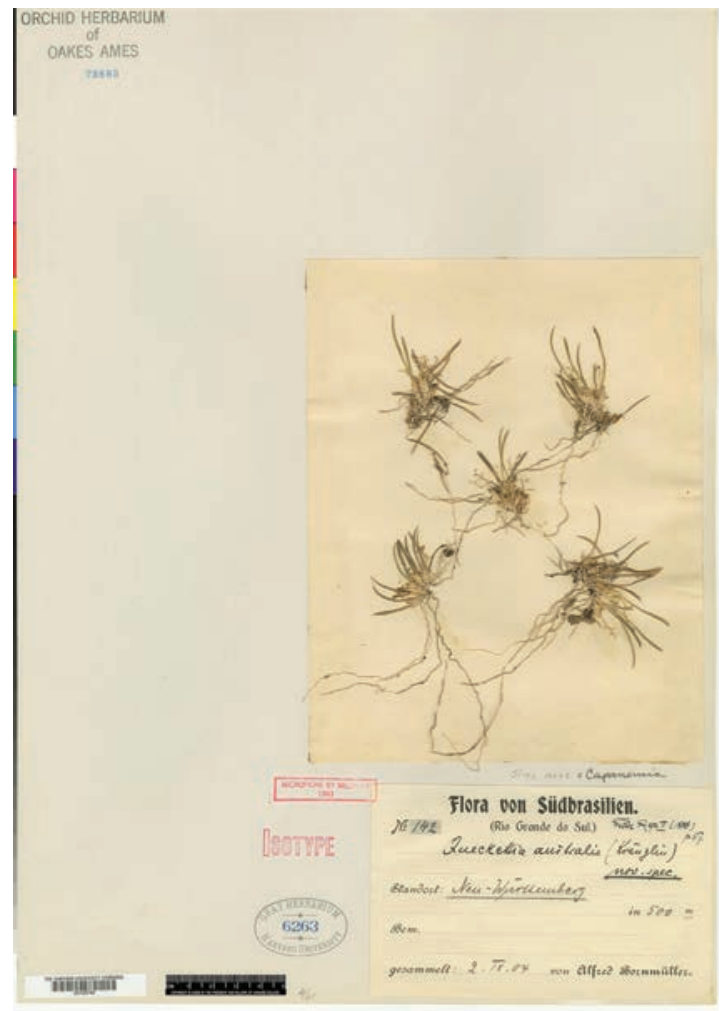

FIgURE 16. Capanemia australis (Kranzl.) Schltr. Isotype, Oakes Ames Orchid Herbarium. 


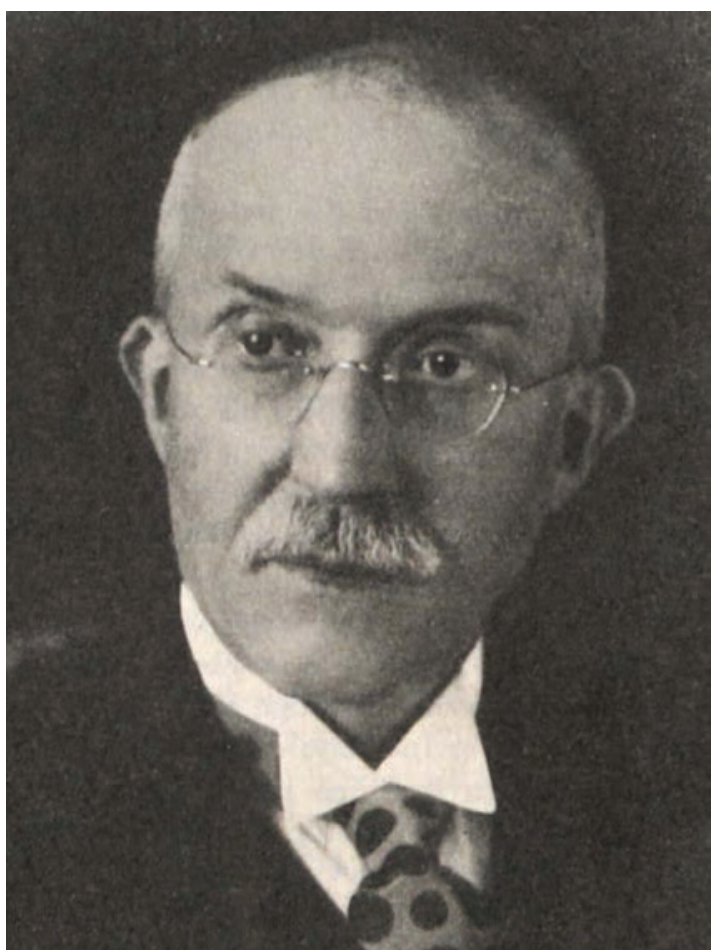

Figure 17. Robert Knud Friedrich Pilger (1876-1953) Archives of Rudolf Jenny. arrival. The expedition took then again the same course as Meyer's first expedition in 1886, sailing upwards on the Paraná and Paraguay Rivers until reaching Cuiabá, in the province of Mattogrosso (Fig. 18).

In the introduction to his Beitrag zur Flora von Mattogrosso ('Contribution to the flora of Matto Grosso'), Pilger gave a short account on his part of the journey: "We landed early February in the capital of Mattogrosso, Cuiabá, where we stayed until the second half of March. The expedition rode from Cuiabá to Rosario and from there to the valley of the Cuiabá River until we reached its headwaters. Continuing then over the water divide [to the Amazon River basin in the north], we crossed the Paranatinga River and arrived finally at the headwaters of the Ronuro River. At this point the expedition, under the leadership of Dr. Meyer, boarded canoes and followed the course of the river while I stayed behind with a few men and went by land, after crossing the Jatobä and Batovy Rivers, back to our main camp. Here we stayed until September, when Meyer's Ronuro's expedition returned. We then went together back to Cuiabá, arriving there at the end of October" (Pilger 1901). It was during the months of April through September that

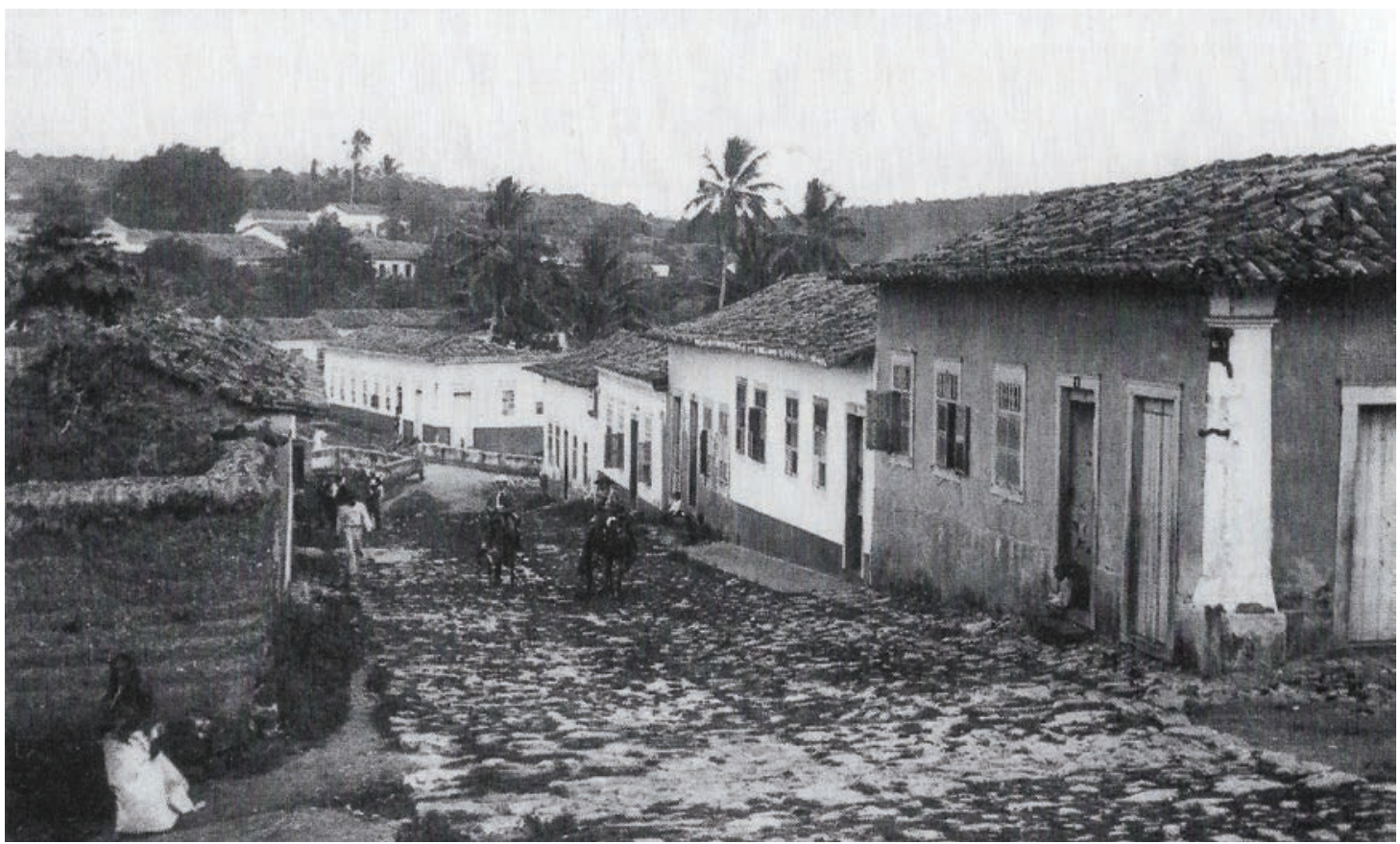

Figure 18. São Rosario street, Cuiabá, 1899. Photograph by Theodor Koch-Grünberg during the expedition. In KochGrünberg 2004: plate 37. 
Pilger made his most important botanical collections which he published in 1901 in the above mentioned Flora von Mattogrosso. In this work, a total of seven species of Orchidaceae was mentioned, all determined by Rudolf Schlechter. It was in fact Schechter's first publication on South American orchids. Among these orchids we find Habenaria pratensis Rchb.f., Pelexia setacea Lindl., Ponthieva mandonii Rchb.f., Galeandra juncea Lindl., Cattleya superba Schombgk. ex Lindl., Oncidium sprucei Lindl., and Habenaria pilgeri, determined by Schlechter as a new species and named by him after Robert Knud Friedrich Pilger (Fig. 19). 700 phanerogams collected by Pilger in Brazil were deposited at the herbarium of the Berlin Museum, all destroyed in March 1943 during the Allied bombings of the German capital (Fig. 20). However, and according to Batista and collagues, the type of $H$. pilgeri is the only type material left at the Berlin-Dahlem Herbarium of Schlechter's New World Habenaria (Batista et al. 2011: 251).

After his return from Brazil, Pilger was named assistant at the Botanical Museum in Berlin, an institution he would serve for the next 50 years. In 1908 he was named curator of the Museum, and in 1913 he became professor. After Engler's retirement in 1921 and having Ludwig Diels been named as his successor, Pilger took over as second Director and played an important role in the upswing of the Museum under Diel's direction, an in the prestigious institution it became in the years prior to World War II.

In December 1934, Pilger made a short trip to Rio de Janeiro, invited by the Brazilian Government to the inauguration of the monument erected in honor of Martius, Eichler and Urban in the city's Botanical Garden, on the occasion of the centenary of the appearance of the general plan to the famous Flora Brasiliensis. During his stay, Pilger made short botanical excursions to São Paulo and the Serra of Itatiaia. Before leaving again for Germany in January of 1935, he was conferred the order of the Southern Cross by the Brazilian Government (Anonymous 1953).

After Diel's death in 1945, Pilger took over as Director of the Botanical Museum in Berlin, a position he held until 1950, the year of his retirement (Eckhardt 1966). He was responsible during this time for the reconstruction of the herbarium after its destruction some years before.

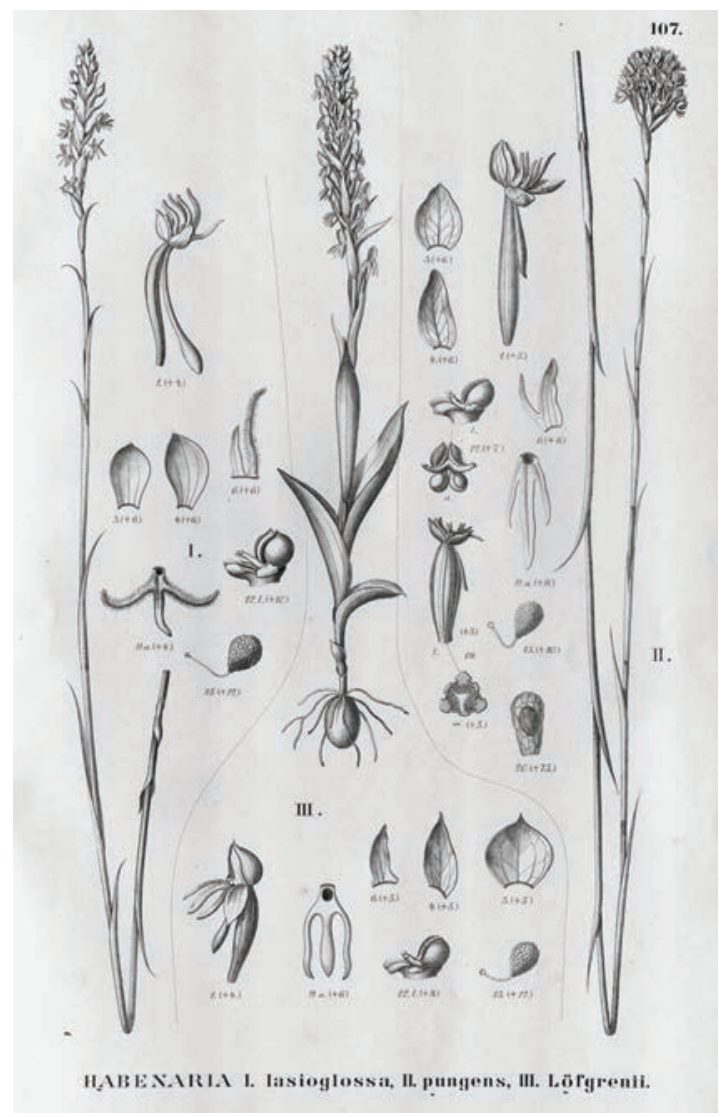

Figure 19. Habenaria pilgeri Schltr. (II, as H. pungens). From Martius et al., Flora Brasiliensis. vol. 3(6), t.107, 1906.

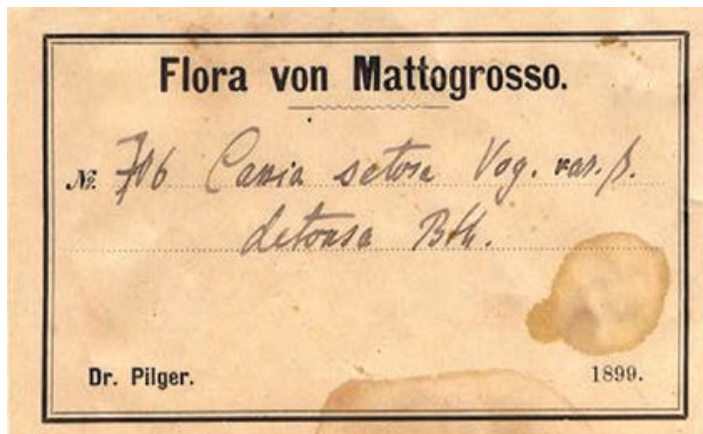

FIgURE 20. Herbarium label of Pilger's Flora von Mattogrosso, 1899. Natural History Museum, Vienna, \#B 100525598.

In the words of Melchior (1955a: 386): "He was a man who embodied the Engler-Diels tradition and who served the Botanical Institute in an exemplary and selfless way". 


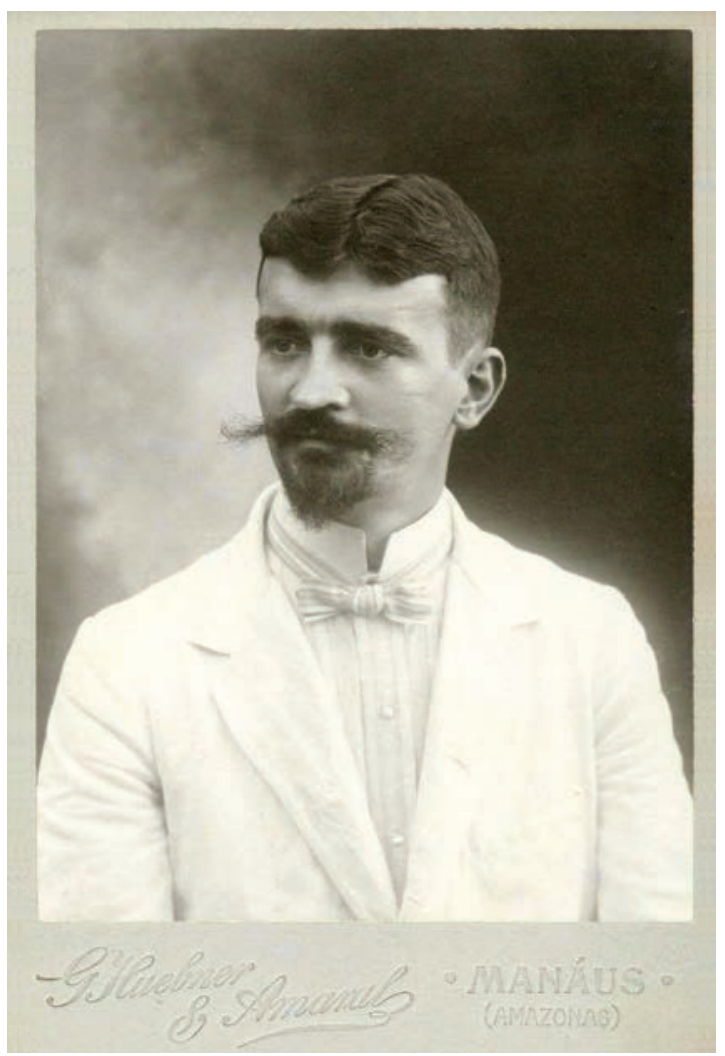

FiguRE 21. Theodor Koch-Grünberg (1872-1924). Photograph by Huebner \& Amaral, Manaus

Christian Theodor Koch-Grünberg (1872-1924; collected 1899-1913)

Probably the most detailed account of Meyer's second exploration of the Xingú headwaters is the journal kept by Theodor Koch-Grünberg (Fig. 21) during the expedition (see Koch-Grünberg 2004). As scientist and photographer he was part of the group that travelled down the Ronuro River. In June of 1899, when everything was lost and the expedition was at its lowest point, he wrote in frustration: "It is a land condemned by God, this Central Brazil, and I pity the poor European who has to live here. The ground is partly a bottomless swamp, partly stone-hard backland where nothing will grow. Trees and bushes are mostly withered cripples; no eatable fruits can be found, and seldom an animal to avoid starvation [...] Wherever you go, death, waste and ruin. Truly, if not absolutely necessary, one should stay at home instead of venturing in this wilderness!".

It seems that Pilger's botanical collections were

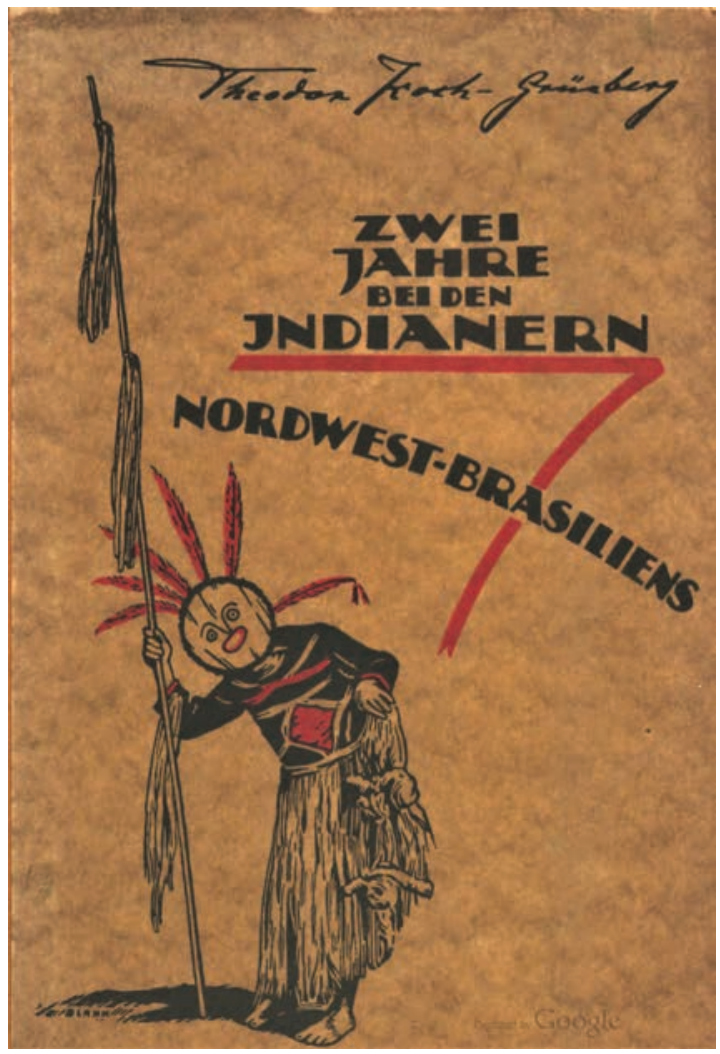

FIGURE 22. Title page of Koch-Grünberg's work: Two years with the Indians in northwestern Brazil (1921)

the only made during the expedition. Koch-Grünberg, in his extensive journal of the voyage (see Kraus 2018) does not make any mention whatsoever on botanical discoveries. Aside from a few general remarks about the vegetation of the regions they passed through, specific plants or flowers are not mentioned anywhere. As we will see, this would change in the travel journals of his future expeditions.

Koch-Grünberg undertook several other expeditions to Brazil after he received his $\mathrm{PhD}$. in 1902 at the University of Würzburg. Sponsored by the Royal Ethnology Museum in Berlin, he started in 1903 on his second exploration journey through northern South America, which would last until 1905. Koch-Grünberg explored for two years the course of the upper Río Negro and its tributaries, including the region of the upper Vaupés River, in Colombia. His two-volume work Two years with the Indians in northwestern Brazil (here cited in its first edition, Koch-Grünberg 1910) (Fig. 22) gave him international fame as scholar 
in the ethnology of the Indian tribes of the Amazon River basin. Koch-Grünberg travelled on this occasion in the company of a young Brazilian of German origin by the name of Otto Schmidt, not to be confused with Heinrich Schmidt, who would travel with him on his third expedition, a few years later.

Koch-Grünberg presented in 1905 a lecture at the Geographic Society in Berlin about this expedition, Report of my travels to the upper Rio Negro and the Caquetá in the years 1903 to 1905 (see here its Spanish version, Koch-Grünberg 1994) in which he wrote: "The most varied classes of orchids have found place in any crevice if the trees, on each dry branch, in any place where they can find nourishment. How many botanical treasures does this unknown and untamed Tropic hide!" And further: "The river became soon very small $[\ldots]$ and disappeared finally into a typical tropical flooded forest, whose exuberant vegetation and extraordinary richness in orchids would captivate the heart of any botanist." "I gave to the Royal Botanical Museum in Berlin a small botanical collection, with some new orchids" (Koch-Grünberg 1906).

A list of the orchids that Koch-Grünberg had sent to Berlin was published later by R. Pilger, in an appendix to Koch-Grünberg's book of 1910 (Pilger 1910: 363-367). Pilger praised Koch-Grünberg's work and affirmed that even small collections made in so far little known regions had great value, especially if -as in this case- they were accompanied by detailed information about the localities were they were found and about their habitat. "They are like blocks which will come together in the future as a large building" (Pilger 1910: 360). Among these, Schlechter described in Martius' Flora Brasiliensis a new genus, Kochiophyton, typyfied by Kochiophyton negrense (a synonym of Acacallis cyanea Lindl.). Schlechter described the origin of his plant as follows "Habitat in truncis arborum ad Cabeceira secus flum. Rio Tiquie affl. Rio Negro prov. Alto Amazonas: Br. Th. Koch n. 114. - Floret Maio" ("Habit on tree trunks at the headwaters of the Tiquie River, a tributary of the Río Negro, province Alto Amazonas: Br[azil]. Th. Koch. Nr. 114 - Flowers in May.”) (Fig. 23).

Pilger enumerated 15 other orchid specimens collected by Koch-Grünberg. The following genera were represented: Batemannia, Dichaea, Epidendrum, an undetermined species of Galeandra, Galeottia,

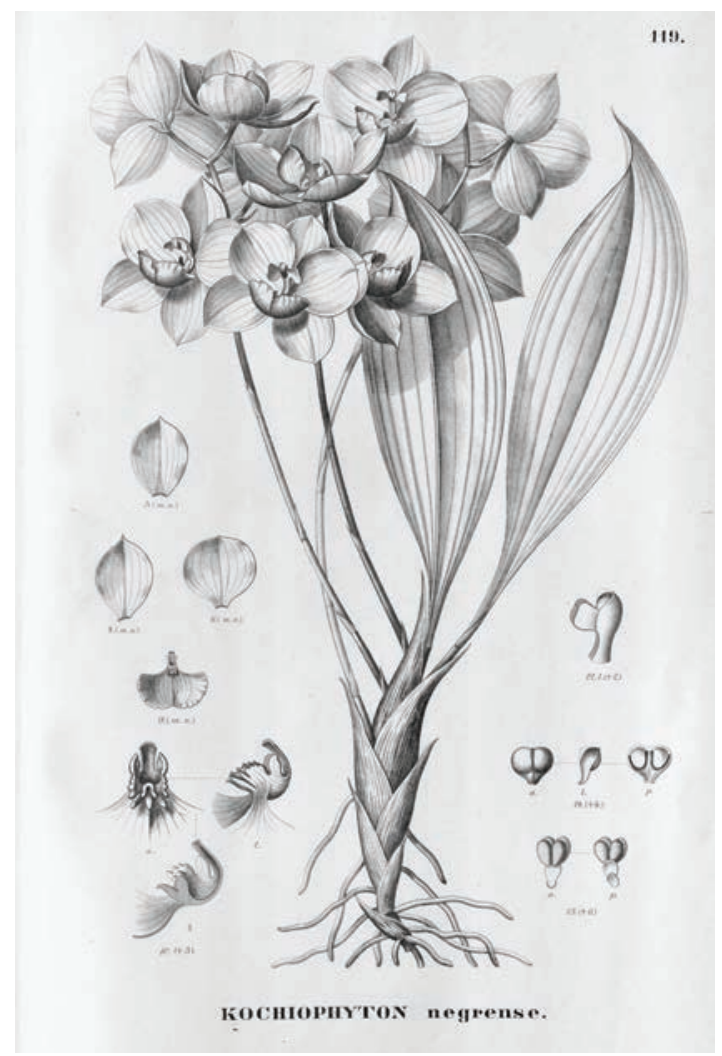

Figure 23. Kochiophyton negrense Schltr. In Pilger, 1910: 366. From Martius et al., Flora Brasiliensis, vol. III(6): plate 119.

Koellensteinia, Maxillaria, Oncidium, Rodriguezia, and Sobralia.

Koch-Grünberg wrote in 1921 once more about the orchids along the Río Negro: "The richness in orchids is extraordinary, and I collected, just in passing by, over half a dozen new species, which stood in flower. On this river, so rich in vegetation, I started to form a small herbarium. However, in this continuously wet weather - we are in the midst of the rainy season - I have little hope of being able to dry the plants properly" (KochGrünberg 1921).

In 1911, Theodor Koch-Grünberg started on his third South American journey, now to the border region between Brazil, Venezuela, and British Guiana, and the Venezuelan lowlands of the Orinoco River basin. In Manaus, he had made the acquaintance of Hermann Schmidt, and Georg Huebner (of whom we will talk later), a German who had emigrated to Brazil around 1901 and had gained considerable experience as a 


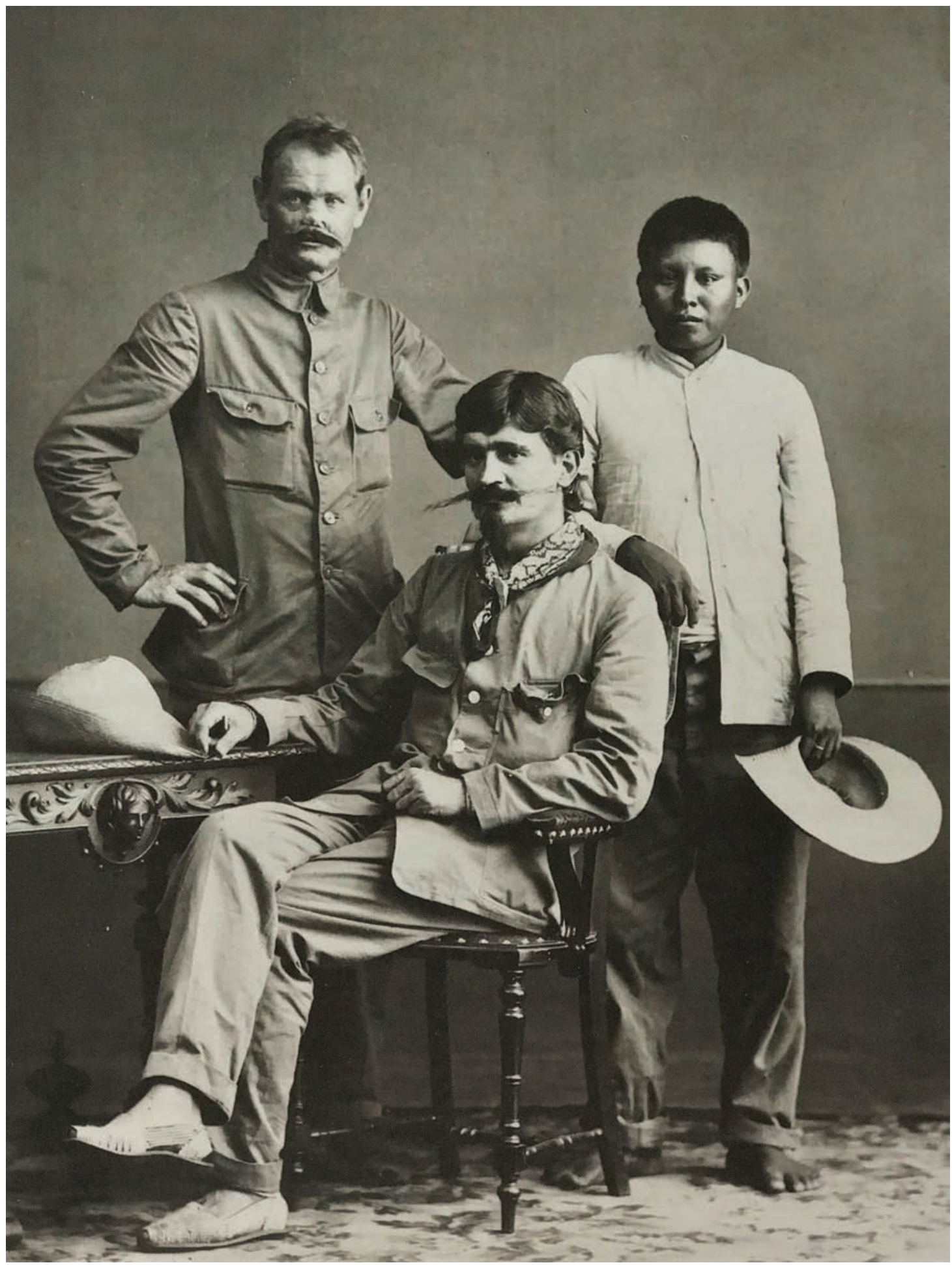

FiguRE 24. Heinrich Schmidt, Theodor Koch-Grünberg, and Romeo Wapixana, Manaus 1913. Photograph by Georg Huebner. 
collector of ethnographic objects in the region of the Río Negro (Kraus 2018). Koch-Grünberg started from Manaus in the company of Schmidt, and an Indian asssistant by the name of Romeo Wapixana (Fig. 24).

Travelling the Río Branco upwards, he reached Mount Roraima in Venezuela. Here he documented the myths and legends of the Pemón and Yek'wana tribes and made important photographic records. He proceeded through the Sierra Parima and the regions of Caura and Venturarí, until reaching the Orinoco on the first of January of 1913. After staying for a short period in San Fernando de Atapabo, then the capital of the Federal Territory of Amazonas, he followed the Casiquiari channel, which connects the Orinoco with the Amazon through the Río Negro. He returned to Manaus and in 1917, back in Germany, published his travel journal, Vom Roroima zum Orinoco, probably his most famous work. In this work, Koch-Grünberg again described the vegetation of the regions he passed through: "The twisted branches of the smaller trees are covered with moss and long, light-green and white lichens, and many other parasites, also flowering orchids." "In the afternoon we went on the other side, and enjoyed a few hours on the canoes between forestcovered islands, from whose tall trees diverse orchids hung" (Koch-Grünberg 1917).

In 1915, Theodor Koch-Grünberg took over the position as scientific director at the Linden Museum in Stuttgart and in 1924 joined the British explorer Alexander Hamilton Rice (1875-1956) on an expedition to the Orinoco River basin. At the beginning of this trip, Koch-Grünberg fell ill, and on October 8, 1924 died of malaria in the Brazilian town of Vista Alegre where he was buried. His gravestone was donated by Georg Huebner.

\section{Georg August Eduard Huebner (1862-1935;} collected 1895-1929)

From Manaus, and with date of December 7, 1923, Georg Huebner (Fig. 25) wrote his last letter to Theodor Koch-Grünberg, his friend of many years who would pass away a few months later, on October 8, 1924: "During the last years I resumed my former occupation, namely the study of orchids. I did this through the encouragement of professor doctor Rudolf Schlechter, an authority in this field. He asked me to collect herbaceous plants, including the smaller and less

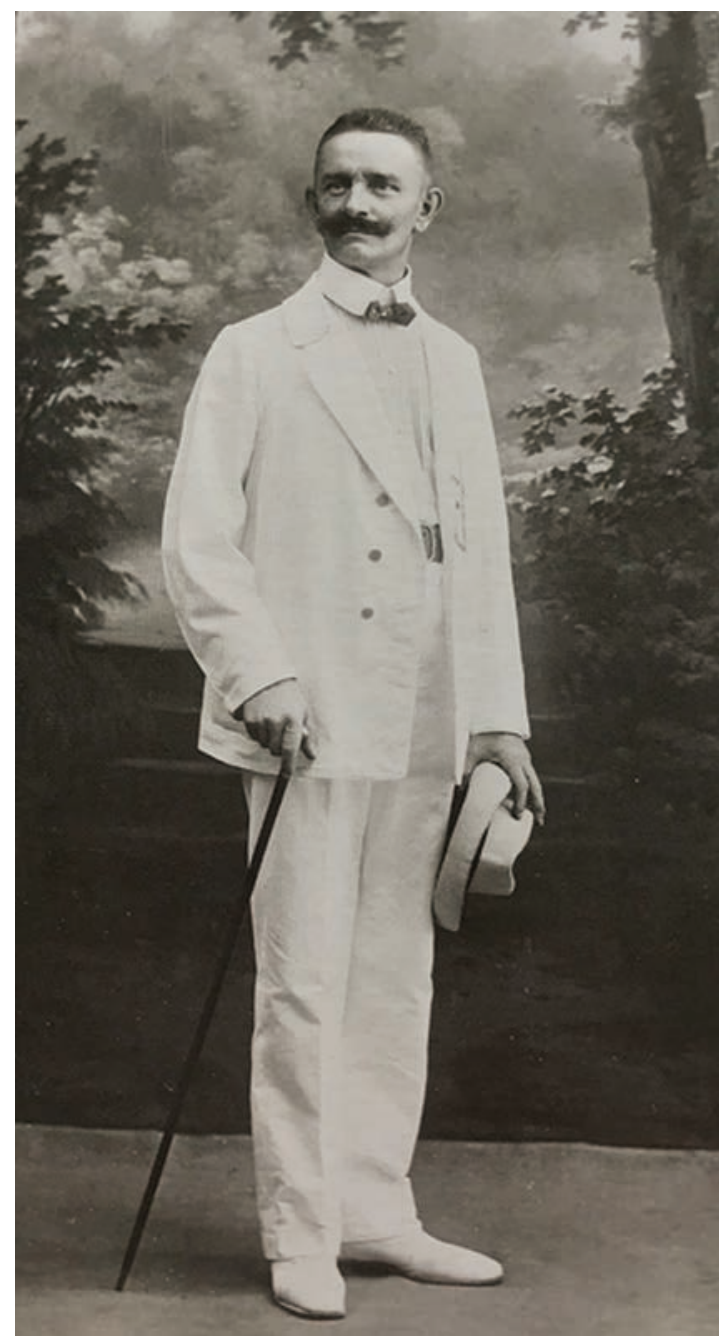

FiguRe 25. Georg Huebner (1862-1935). Self-portrait, 1910.

important species, many of which are still unknown. I undertook this work with the intention of improving the knowledge about Brazilian orchids and it will be published in Portuguese in the Anexos das Memórias do Instituto de Butantan by doctor Schlechter and by doctor F.C. Hoehne, in São Paulo, with whom I correspond frequently (see Schlechter \& Hoehne 1926, a translation of Schlechter 1925). To my regret, work was interrupted recently by Dr. Schlechter's illness who suffered a nervous breakdown due to excessive work. Now, since I know he has recovered, he will be able to occupy himself with the material I have sent him. It is true that I dedicate my time to activities of little profit, but I am very happy to know that among 


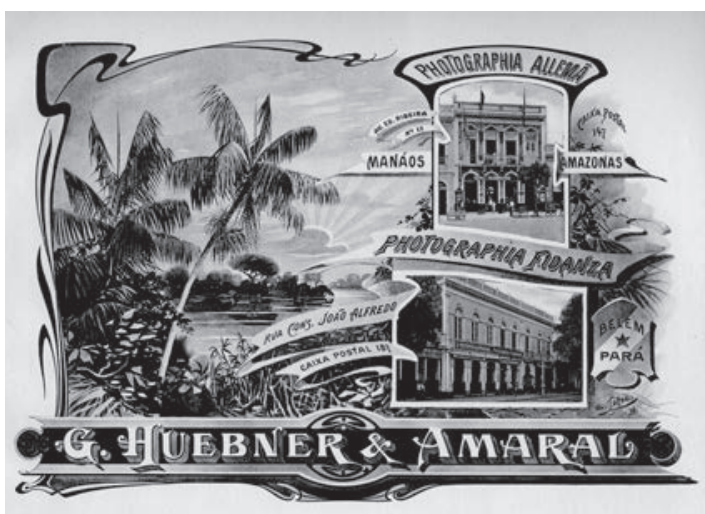

FigURE 26. Promotional leaflet of Hubner \& Amaral's photographic studioos.

the samples I collected a century of species were new, which allows me to make a small contribution to science. At this moment I intend to turn this into a lucrative activity, approaching the importers of live orchids and offering my services, since I acquired a certain experience in this matter when I worked as a plant collector for Linden-Brussels in the 1890's" (Schoepf 2005: 194).

Georg Huebner, born in the German city of Dresden, came for the first time to South America in 1885 , and was active during almost two years in the rubber business in the Peruvian Amazon. In 1888 Huebner travelled to Lima, where he met the Alsatian photograph Charles Kroehle (?-1902) with whom he travelled during three years through eastern Peru. They opened a photo studio in Iquitos under the name of "Fotografía del Amazonas" and took photographs which Huebner sold in Germany, after his return in 1891, and the failure of his business in Iquitos ( $\mathrm{La}$ Serna 1918, Wolff 2014). Before sailing back to Germany, he worked for a time as plant collector for the Linden nurseries in Brussels.

Huebner travelled in 1894 a second time to the Amazon region, where he undertook an exploration along the Río Branco, a tributary of the Río Negro. This journey took him to the headwaters of the Orinoco River and, besides a botanical collection, he made a large number of photographs which - again - he sold mainly in scientific circles. In 1897, Huebner moved finally to Manaus, a city marked by the rubber boom, on the confluence of the Amazon and the Río Negro. Here, he offered his services as landscape and portrait

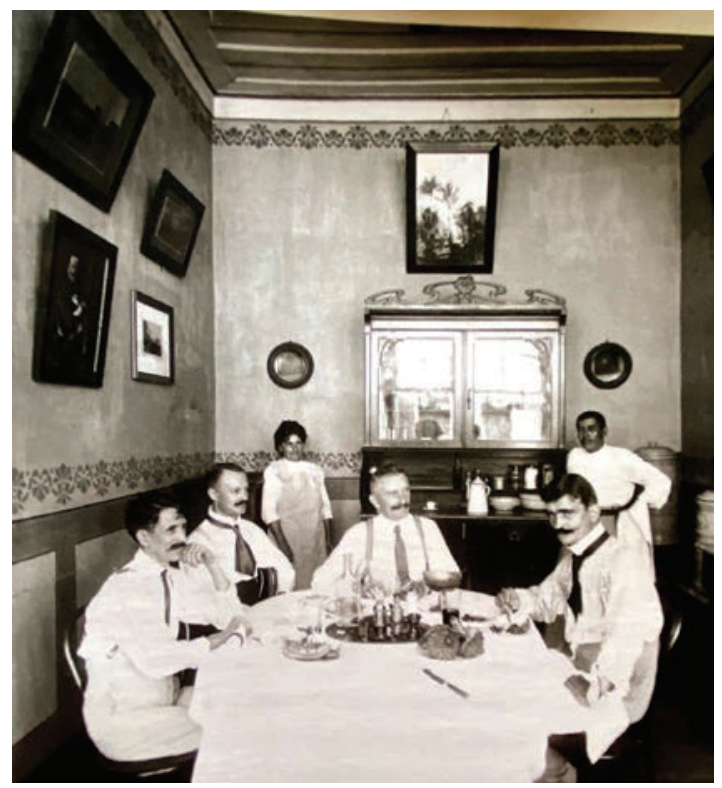

Figure 27. Breakfast at the "Photographia Allemã". Center: G. Huebner. Right: T. Koch-Grünberg

photographer and opened in 1899 an atelier under the name "Photographia Allemã" (German photography), which developed into the most important for photographic services in the region. The art teacher Libanio do Amaral became in 1901 Huebner's partner in his expanding business. The two partners adquired later in Belém the atelier of the recently deceased Italian photographer Felipe Augusto Fidanza and opened in 1911 a branch in Rio de Janeiro (Fig. 26).

Huebner maintained intensive contact to European scientific circles and to individual researchers, besides the already named Theodor Koch-Grünberg also to the botanist Ernst Ule, of whom we will talk next. He had in Koch-Grünberg a lifelong friend (Fig. 27).

In 1920, after the death of his partner Amaral, and in view of the crisis in the rubber business, Huebner retired from his profession and sold his studios in Manaus, Belém and Rio de Janeiro. He dedicated himself for the rest of his life to his botanical passion, the cultivation and commerce with orchids.

Huebner's photographs and postcards became with the years collector's ítems (Fig. 28-29).

His orchids achieved world fame through Rudolf Schlechter's publication of 1925, Contributions to the orchidology of the Amazon Region, Orchidaceae 


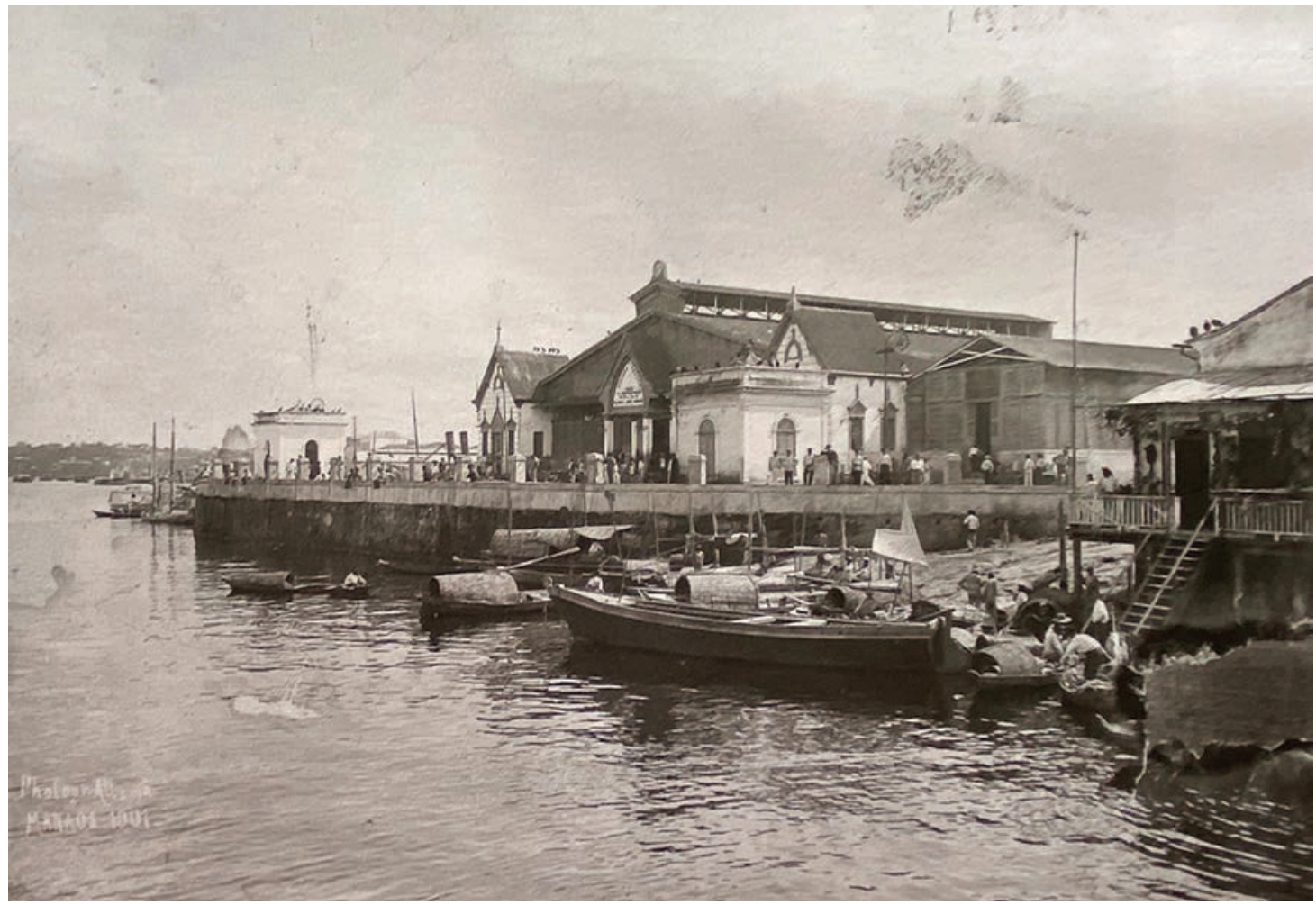

FIgure 28. Public market in Manaus. Photograph by Georg Huebner.

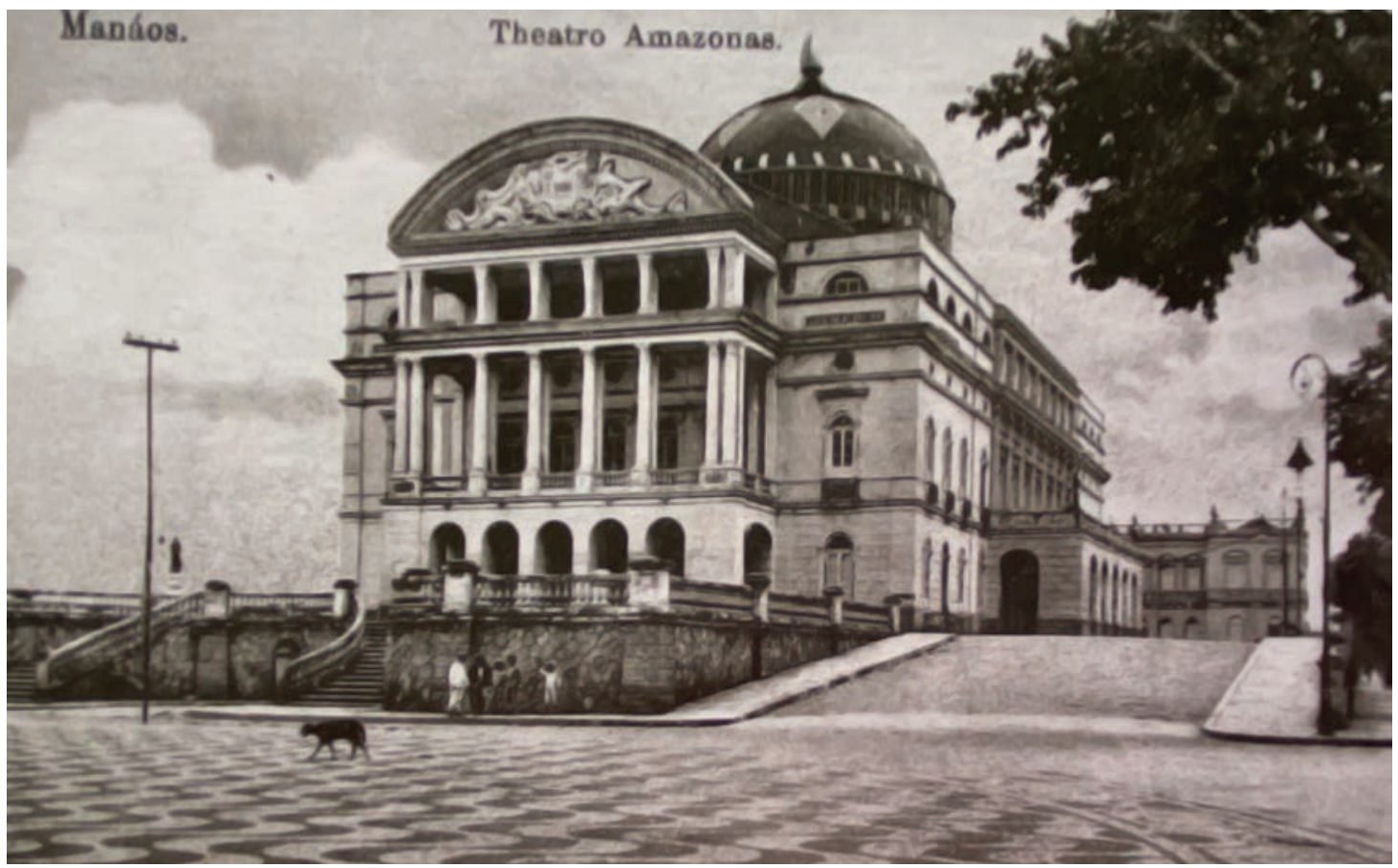

Figure 29. Theatro Amazonas, Manaus. Postcard by Huebner \& Amaral. 


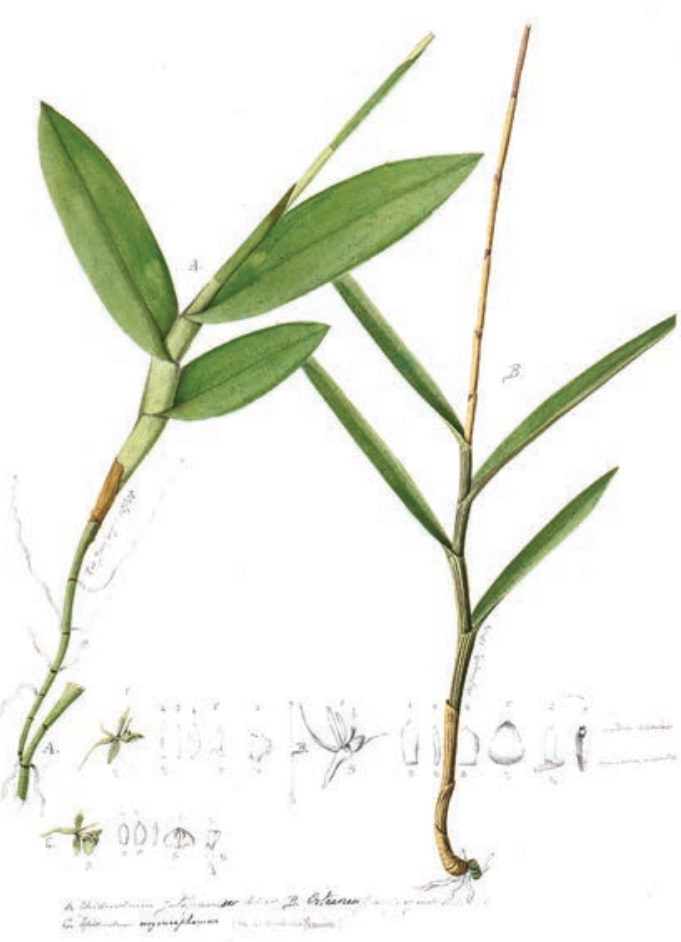

FIGURE 30. Huebneria yauaperyensis (Rodr.) Schltr. Illustration by Barbosa Rodrigues in Flora brasiliensis, vol. 4: plate $2 \mathrm{~B}$.

Hueberianae. In the introduction to this work Schlechter wrote: "Never has a collection of dried orchids of the Amazon region been put together as extensive as that which Mr. Georg Hübner collected for me. His collection encompasses some 200 numbers and is constantly growing [...] All other collections cannot be compared with that of Hübner and his collection is therefore the most important which we have received so far from the Amazon region" (Schlechter 1926).

Among Schlechter's descriptions of Huebner's orchids, we find a total of 51 new species, of which he dedicated 14 to Georg Huebner, including one new genus: Huebneria [with the type species Huebneria yauaperyensis (Rodr.) Schltr.] (Fig. 30). The others were Brassia huebneri, Encyclia huebneri (Fig. 31), Epidendrum huebneri, Galeandra huebneri, Habenaria georgii, Masdevallia huebneri, Maxillaria huebneri, Pleurothallis huebneri, Polystachya huebneri, Rodriguezia huebneri, Scaphyglottis huebneri, and Stelis huebneri.

Schlechter had published, in 1926, the first 193

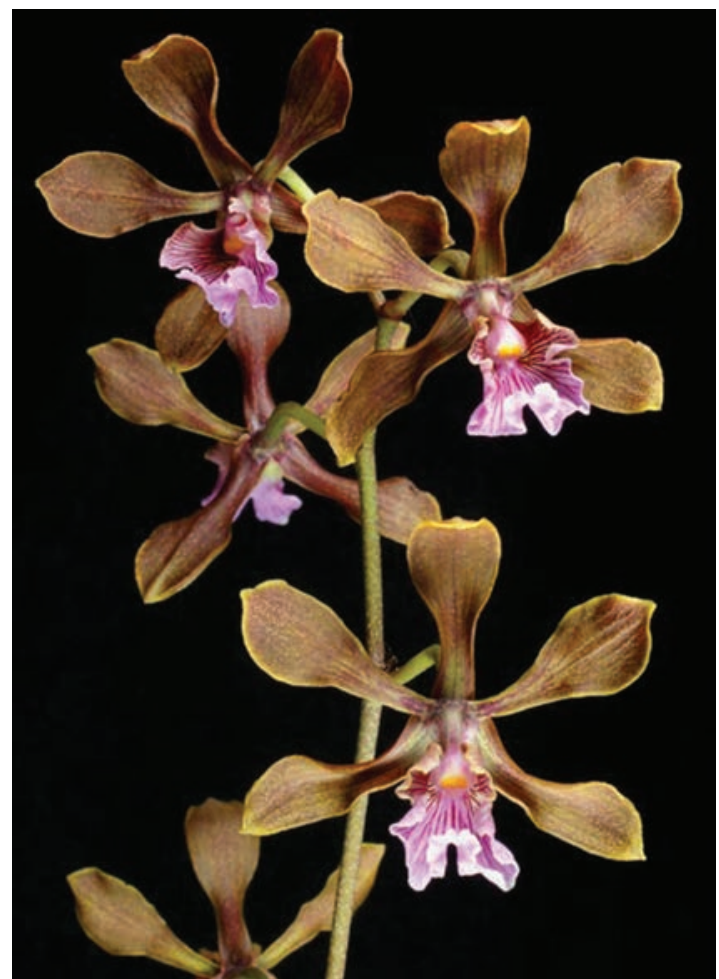

FIGURE 31. Encyclia huebneri Schltr. Unknown photographer.

numbers collected by Huebner (Schlechter 1926: 83150). In 1928, after Schlechter's death, his successor Rudolf Mansfeld continued with this work, and published Orchidaceae Amazonicae Huebnerianae which included 102 additional specimens, Huebner's numbers 194 to 296. Among these, Mansfeld (1934) dedicated another two new species to Huebner: Campylocentrum huebneri and Catasetum huebneri. In 1934 Mansfeld described again two additional new orchids among Huebner's collections: Hybochilus huebneri (collected in Colombia) and Sigmatodtalix huebneri.

Georg Huebner, aside from being an outstanding orchid collector, with a privileged eye for new species, must be regarded also as a magnificent photographic recorder of people, landscapes, villages and cities in the Amazon region. His photographs, not only from the point of view of technical perfection, but also as magnificent artistic compositions, constitute a monument to his almost 50 years in South America, and especially to his more than 30 years in Brazil. He spent the last years of his life in the village of Cacau 
Pirêra, in the outskirts of Manaus. Huebner only went into the city to look after mail in the post office, and to bring occasionally new orchid species to the "Orchidario Amazonense", a private garden property of J. Gunzbürger, another German immigrant (Schoepf 2005: 209). Huebener died of a stomach illness on April 20, 1935, and was buried in Manaus.

Huebner's photographs were often used by other botanists in their publications. During the earlier stages of his travels on the Juruá and Madeira rivers, Ernst Ule (1854-1915) did not feel that he had sufficient practice as a photographer (Ule 1904). "This explains why Ules's first detailed publications on rubber tapping aside from one exception - featured pictures by Brazilbased photographer Georg Huebner" (Kraus 1915). Of Ernst Ule we will read next.

Ernst Heinrich Georg Ule (1854-1915; collected 1893-1912)

Ernst Heinrich Georg Ule (Fig. 32) was born on in 1854 in Halle an der Saale, Germany. His father, Otto Eduard Vincenz Ule, was a science writer, who inspired Ernst and his brother, Wilhelm in their love for science. Ernst Ule very early showed a marked interest in the natural world, his main interests aimed at the botanical sciences. Wilhelm became a Professor of Geography at the University of Rostock. After completing his first education in his hometown, Ule attended horticulture clases in Proskau, where he received his training from the well-known plant pathologist Paul Sorauer. Ule worked then for a short period as gardener at the botanical garden in Halle and moved in 1877 to Berlin. $\mathrm{He}$ decided to continue his education in Coburg, but began to show the sequels of the scarlet fever he had contracted when young. He started showing signs of mental disorder and a serious spell forced him in 1880 to abandon school and to go into psychiatric care. Whether by luck, healing, or divine intervention, Ernst was able to re-enter society and by 1883 he had made a complete recovery (Harms 1916).

Since he had fallen behind in school because of his illness, Ernst Ule decided that a change in climate and environment would help and so he sailed in 1883 to Brazil. He worked as a tutor in the state of Santa Catharina and started plant collecting after he was named "naturalista viajante" by the National Museum in Rio de Janeiro (Fig. 33).

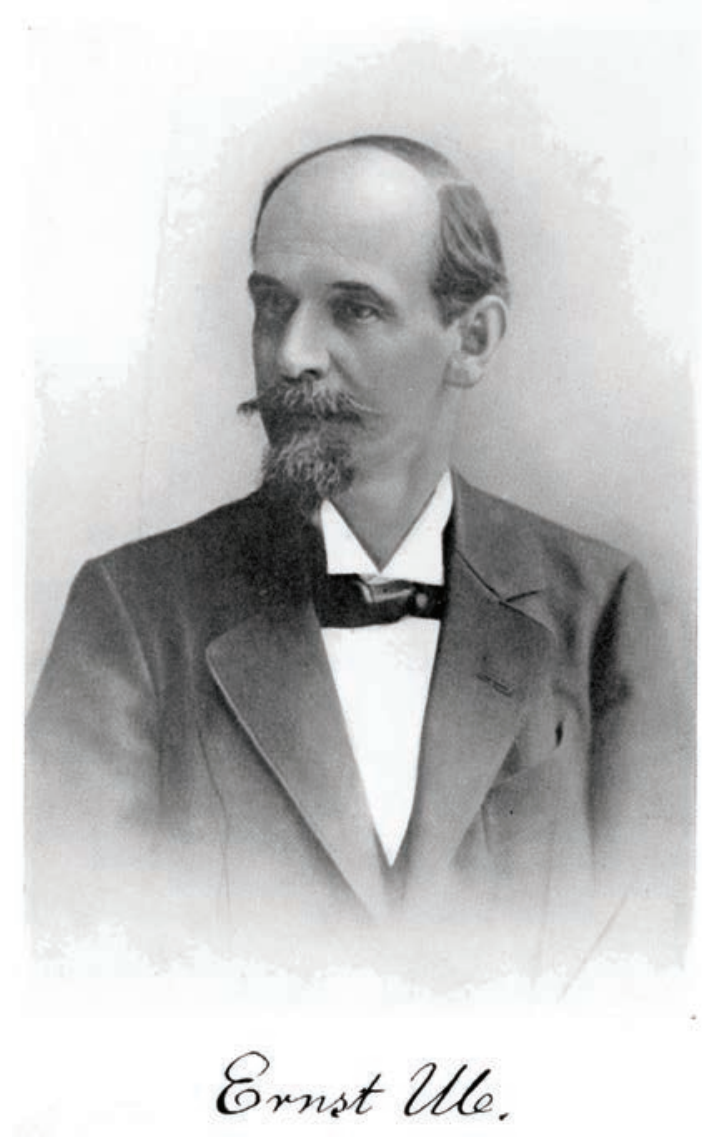

Figure 32. Ernst Heinrich Georg Ule. Photograph by KochGrünberg. In Harms (1916).

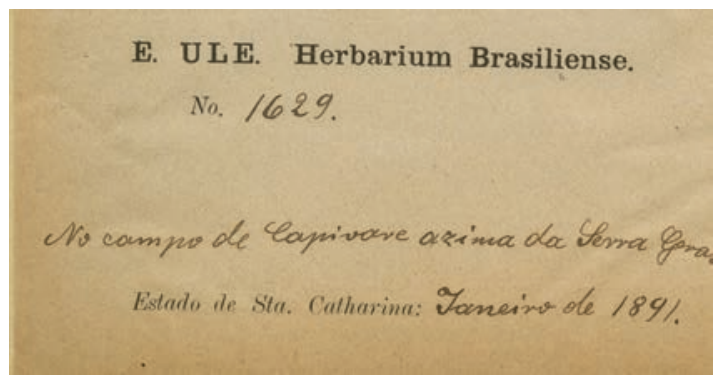

FIGURE 33. Herbarium label of Ule's "Herbarium Brasiliense".

He made a rapid career at the museum and was named subdirector of the Department of Botany, a position he held from 1885 to 1890 (Harms,1916: 5), with an interruption between 1888 and 1889, when he returned to Germany and worked at the Royal Botanical Garden to use the herbarium to verify his Brazilian plant 


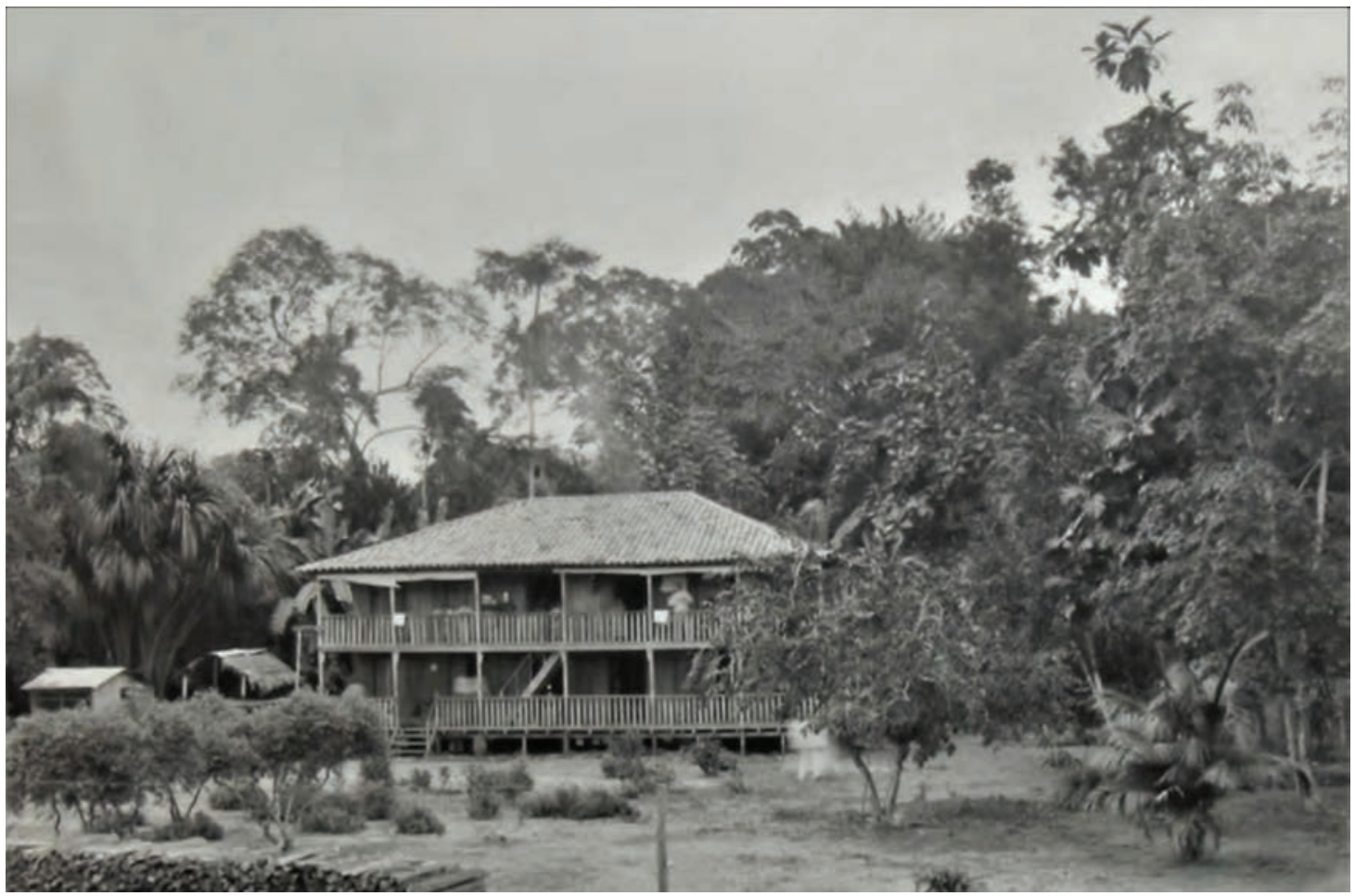

FiguRE 34. Research station Foz de Copéa on the Solimões, Upper Amazon (29 April 1903). Photograph by E. Ule. In Kraus (2015).

collections. He was then dismissed from the position at Brazil's National Museum, a political move borne of accusations that his botanical labors were intended to benefit foreign and not Brazilian entities (Harms 1916). This marked the beginning of a career as an independent plant collector and researcher, which would continue for the rest of his short life. The most productive period in his life began in 1900, when he undertook expeditions into the Amazon region, regularly interrupted by short visits to the Berlin herbarium, to determine his botanical collections.

His first large expedition took him to Manaus, from where he explored the upper Amazon in Brazil and well into Peruvian territory. It all began in 1899 , when an excursion to tropical South America was organized with the support of the leaders in the import of raw materials and the manufacture of rubber products in Germany. The purpose was to study the distribution and ecology of rubber plants. It was an unfortunate coincidence that Dr. Kuhla, a young botanist from the Botanical Institute of Marburg, who had been chosen to accompany the expedition, fell ill after only a month on the job, and died of fellow fever. Thus, Ule was called to fill his place (Ule 1901: 111).

This trip involved extensive studies on "rubber tapping and rubber trading" and saw Ule travel to the regions of the Río Juruá, the Río Madeira, the Río Negro and finally the Río Huallaga and the eastern slopes of the Andes in Peru (Fig. 34).

In 1903, Ule traveled back to Germany to study and classify the botanical collections he had compiled on his travels. He stayed in Berlin until 1906, made a short trip to Bahia in 1907 and started in 1908 on his largest and last expedition to South America. He arrived in Manaus on 1 September 1908 and his first excursion took him upwards the Río Negro, and then into its tributary, the Río Branco. He intended to continue much further north, but attacks of malaria and severe leg wounds forced him to consider returning to Manaus, where he arrived in April 1909. After recovering from his illness and wounds, he started again on 1 June 1909 in the same direction and finally, early December, the region of sandstone mountains on the frontier with Venezuela was reached and they came nearer to Roraima, now visible in 


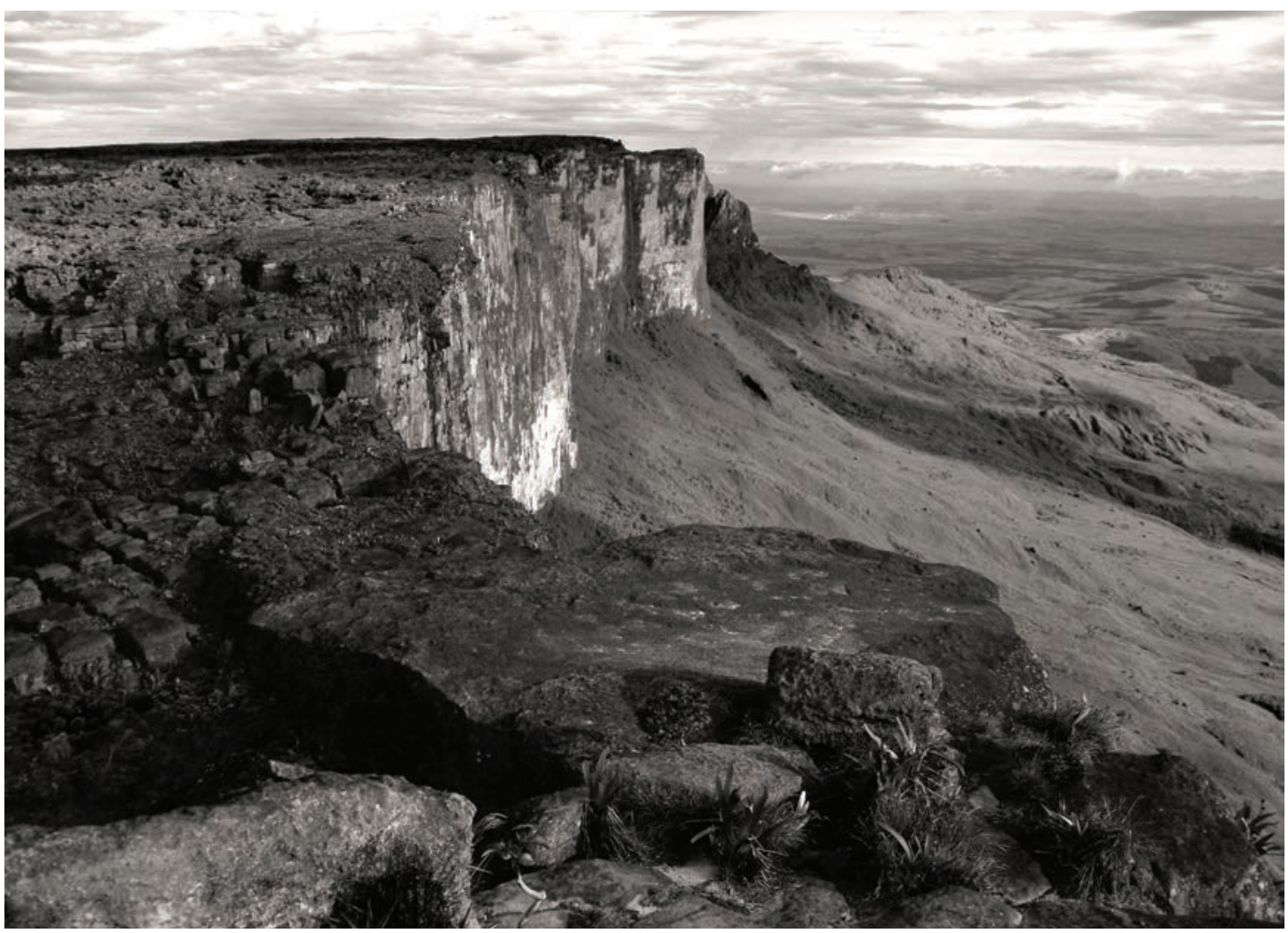

FIGURE 35. Mount Roraima, Venezuela. Unknown photographer.

the distance (Fig. 35). The mountain was reached soon, and, "in order to be able to collect most conveniently on Roraima, Ule installed himself in a forest hut situated at about $1900 \mathrm{~m}$ on the slope of the mountain where the real ascent begins. He stayed there for seven weeks and climbed to the high plateau four times, making rich botanical collections (see Ule 1914a). In February, 1910, he set out on the return journey to Manaus, where he arrived in April." Ule now stayed for a while in the city, to organize his collections and prepare for a new journey (Harms 1916).

The last leg of Ule's expedition began when the Commercial Association of the Amazon proposed to Ule a new expedition, this time to the region of then Río Acre, near the borders of Bolivia and Peru. Then, the journey had to be postponed several times due to new attacks of malaria, but Ule finally departed in December 1910, sailing westwards on a tributary of the Amazon until reaching the mouth of the Río Acre in February 1912 (Fig.36).

Ule remained in the region until October and made numerous excursions into the forests. On 6 November he returned to Manaus but reached the city only in February 1912, long delays being unavoidable due to either insufficient water levels or mechanical problems of the ships involved.

On 17 March, 1912, Ernst Ule departed from Manaus, never to return to South America again; on 10 April he arrived in Berlin. The rest of his life, only 3 years, was dedicated to determining his botanical collections, which proved to be of great scientific value. Hermann Harms, perhaps the best of his biographers, who knew him personally and called himself his friend, described Ule's botanical work with these words: "When we survey the life work of our researcher, we must first of all remember the extensive collections, which are among the most valuable which we possess from Brazil. The number of plants collected by him runs to about 17,000 numbers or somewhat more. Of these, somewhat more than 10,000 are allotted to the separately numbered Phanerogams (including the Pteridophytes); the remainder consist of Cryptogams, 


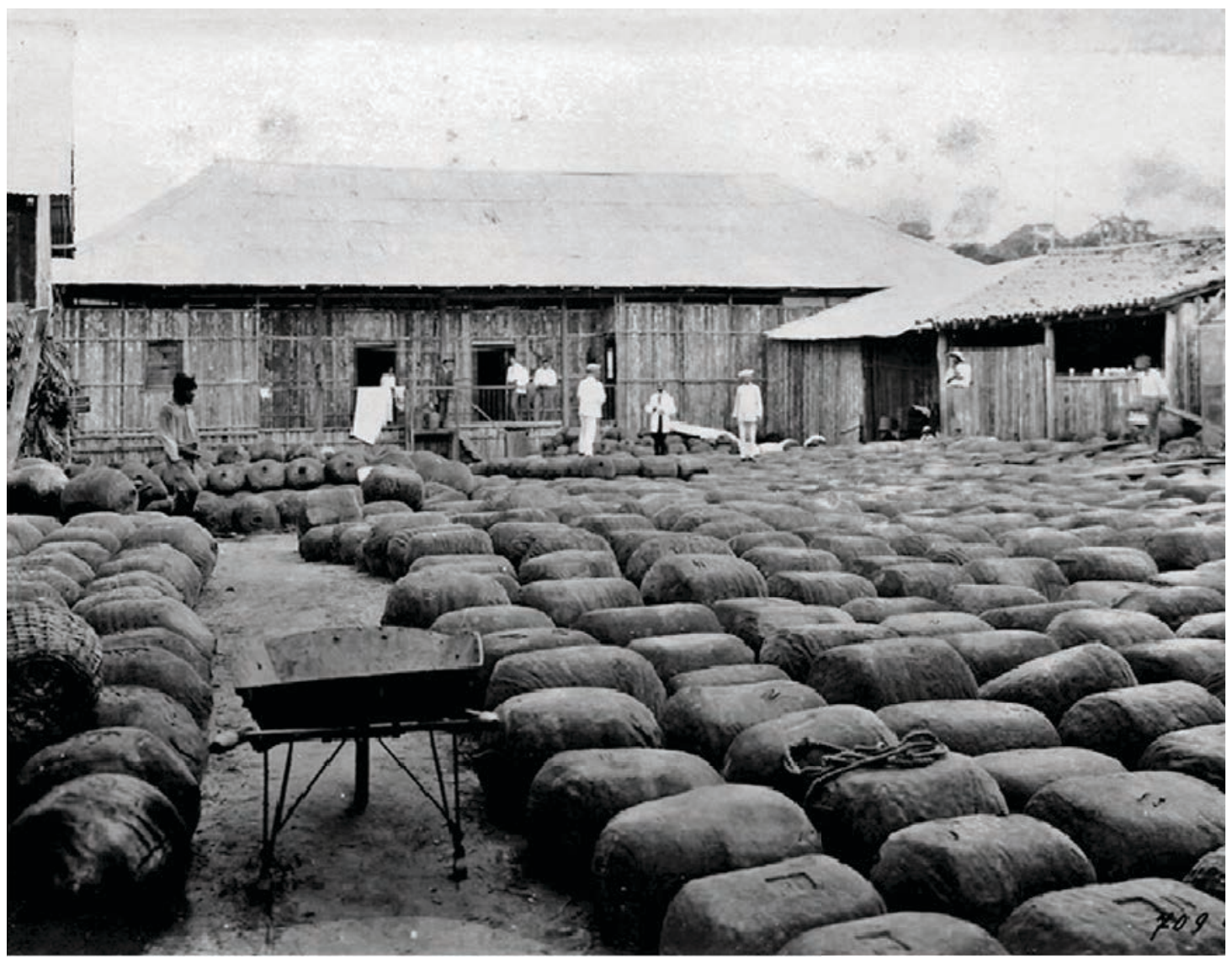

FIGURE 36. Rubber balls ready for export in Cobija, upper Acre River, 1912. Photograph by E. Ule.

which are again numbered by group (2500 mosses, 666 liverworts, 3527 fungi, 366 lichens, 46 algae). The large number of Cryptogams is remarkable, especially of Bryophytes and fungi, both groups in which he had shown a special interest at the beginning of his career. He had distributed collections of exsiccatae of Bryophytes and fungi more than once. Just because of his preference for Cryptogams, he accomplished very much increasing our knowledge of the richness of these plants in South America." (Harms 1916).

In Ule's report on his second expedition (Ule 1914), he makes frequent mention of orchids. It does therefore not surprise us, that many new species were later discovered amonst his collections. Robert Pilger published in 1914 a list of the new or little known species of plants collected by Ule during his last expedition, under the title Plantae uleanae nova vel minus cognitae (Pilger 1914). In this work, the orchids were again described by Rudolf Schlechter. Thirteen new species were described, among them three which were dedicated to Ernst Ule: Habenaria ernestii, Masdevallia ulei and Epidendrum ulei.

In addition, Hoehne established the new genus Uleiorchis (Fig. 37) and dedicated to Ule the new

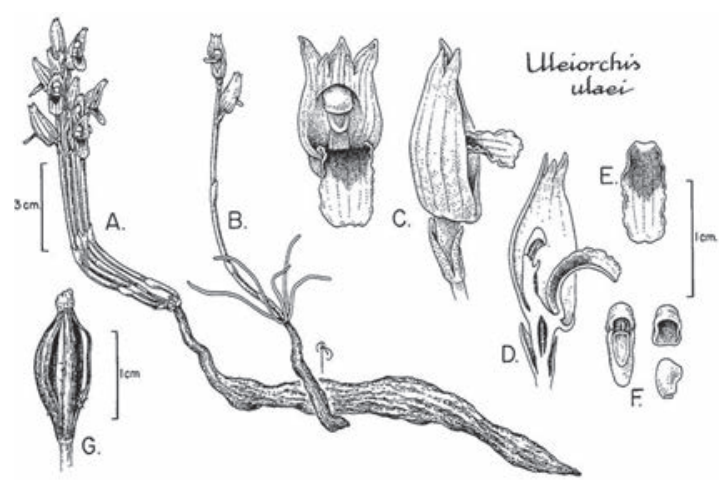

FIgURE 37. Uleiorchis ulaei (Cogn.) Handro. Drawing by Bobbi Angell, New York Botanical Garden. 


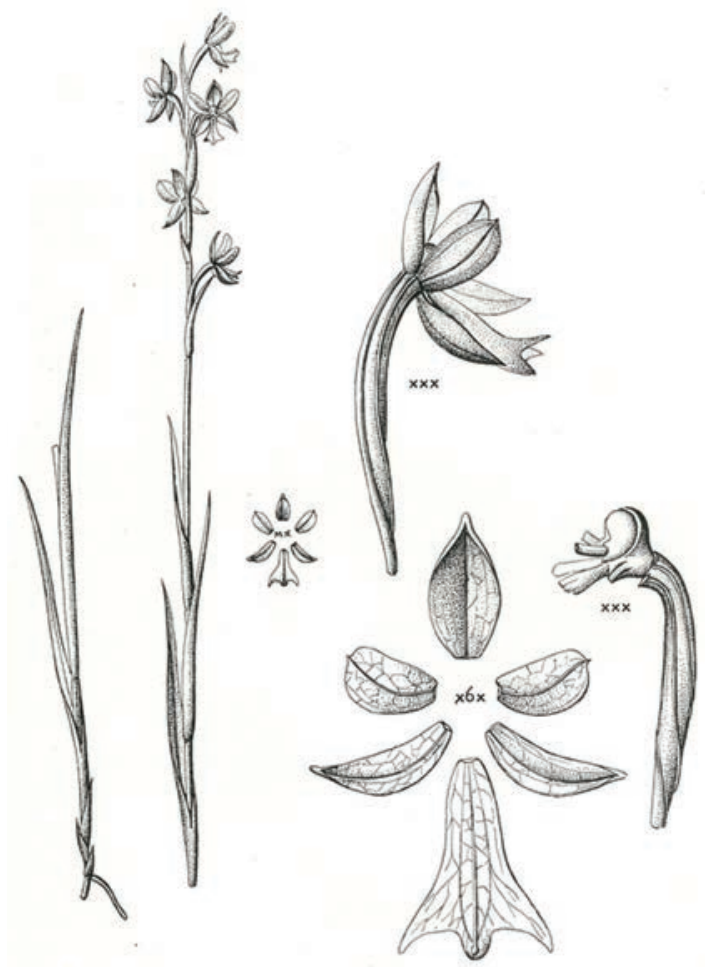

FIgure 38. Itaculumia ulaei Hoehne. In F.C. Hoehne, Flora Brasilica: plate 123 .

species Itaculumia ulaei (Fig. 38) and Habenaria ernesti-ulei. Cogniaux dedicated to Ule his Spiranthes ulei, Campylocentrum ulaei, Habenaria ulaei, and Physurus ulaei.

Finally, Hágsater named in Ule's honor Epidendrum uleinanodes. The Oakes Ames Herbarium holds several drawings of orchid types collected by Ule (Fig. 39).

JACQues Huber (1867-1914; collected 1895-1914) and Walter Adolpho Ducke (1876-1959; collected 1899-1959)

In 1866, the Brazilian naturalist Domingo Soares Ferreira Penna (1818-1888), under the influence of the Swiss scientist Jean-Louis-Rodolphe Agassiz (18071873), founded the Sociedade Filomática do Pará, a Brazilian scientific association dedicated to the study of the natural history of the Amazon region. Ferreira Penna, during his time one of the most important researchers of the Amazon, directed the Sociedade Filomática towards its first important objective, the

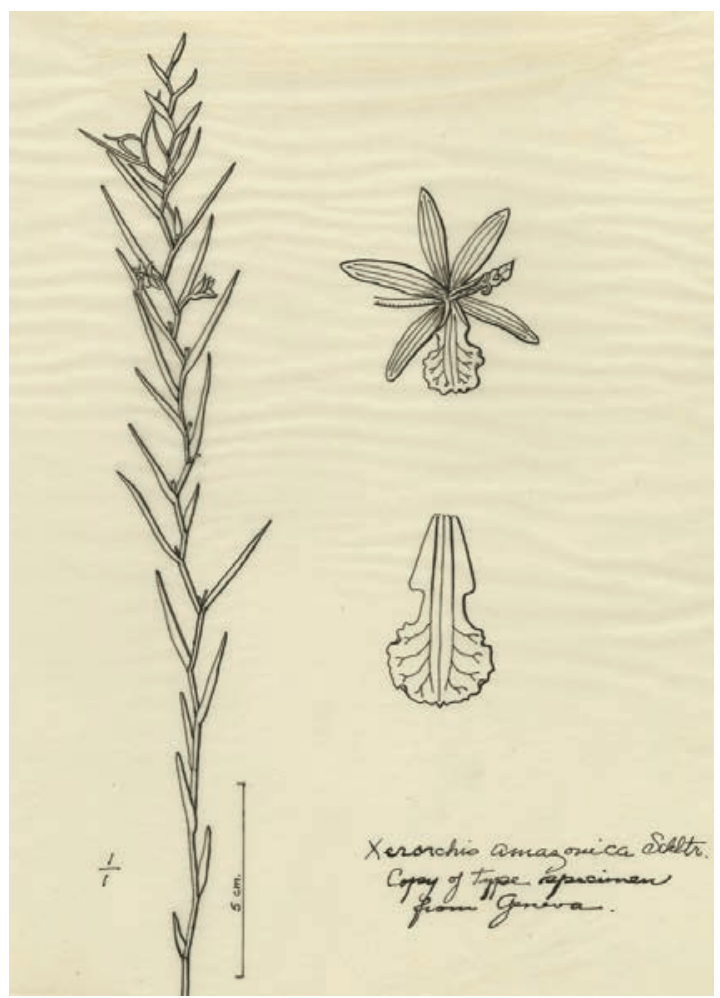

FIgURe 39. Xerorchis amazonica Schltr. Drawing from the type at the Oakes Ames Herbarium, \# 00084541.

foundation in the city of Belém of the Pará Museum of Natural History and Ethnography (Fig.40).

In the meantime, the Swiss zoologist Émil August Goeldi (1859-1917) (Fig. 41) was invited in 1884 by Ladislau de Souza Mello Netto, director of the Brazilian Museu Imperial to work at that institution. Goeldi arrived in Rio de Janeiro in 1885 but was fired from the Museum five years later, due to political circumstances related to the military coup which overthrew the government of the Brazilian Empire and the proclamation of the republic. It was then that the governor of the state of Pará invited Goeldi to reorganize the Museum, which had fallen into a state of abandon, especially after Ferreira Penna's death in 1888 (Florez et al. 2018).

Goeldi began looking for qualified collaborators. Jacques Huber (1867-1914) (Fig. 42) applied for the position of botanist and after being admitted arrived in Belém and took charge of his new post in July of 1895 (Aerni 1992: 88). Soon the Museum and the gardens experienced a profound transformation (Fig.43A-B). 


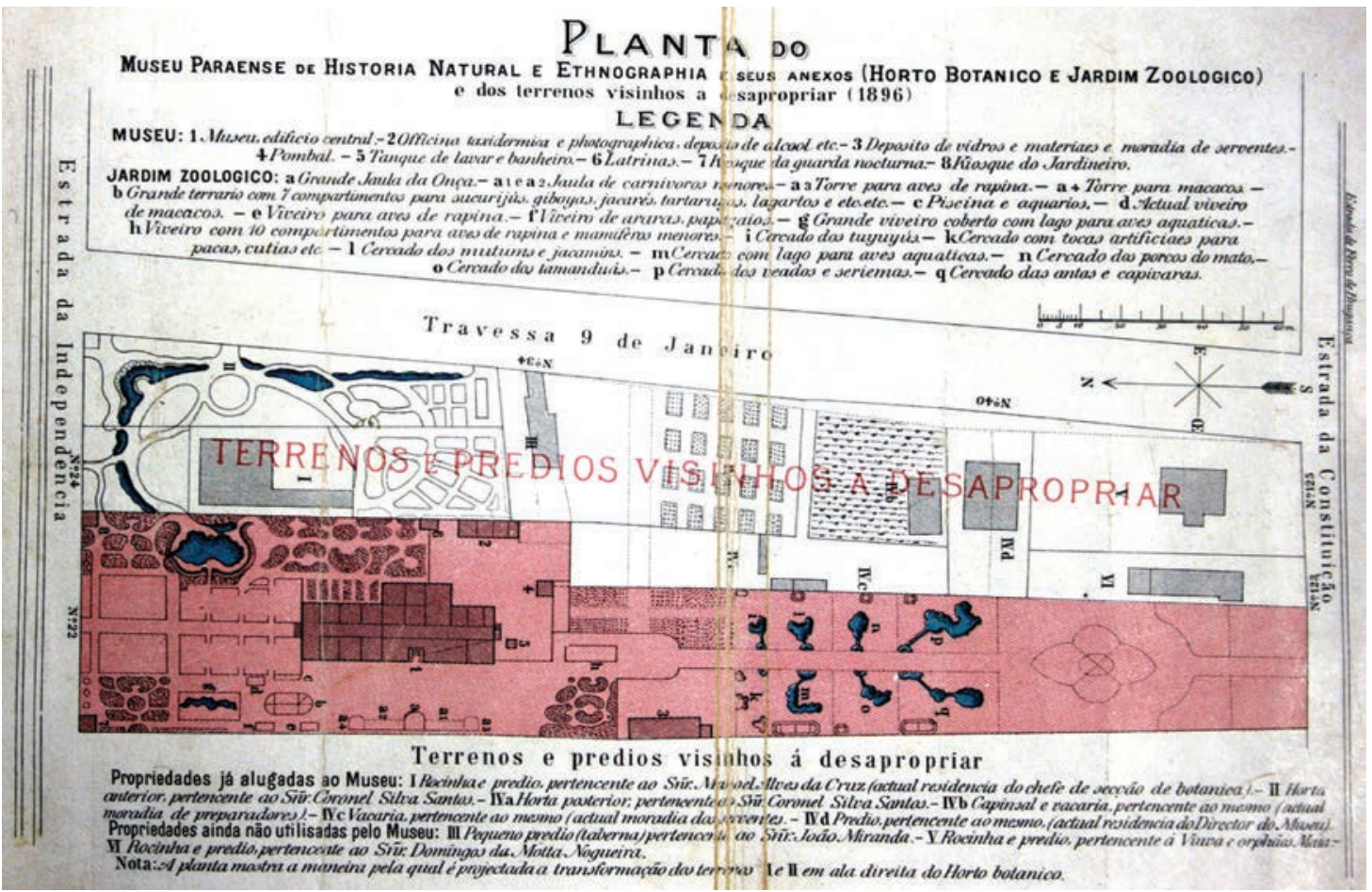

Figure 40. Museu Paraense de História Natural e Etnografía. Site plan in 1896. In Florez et al. 2018.

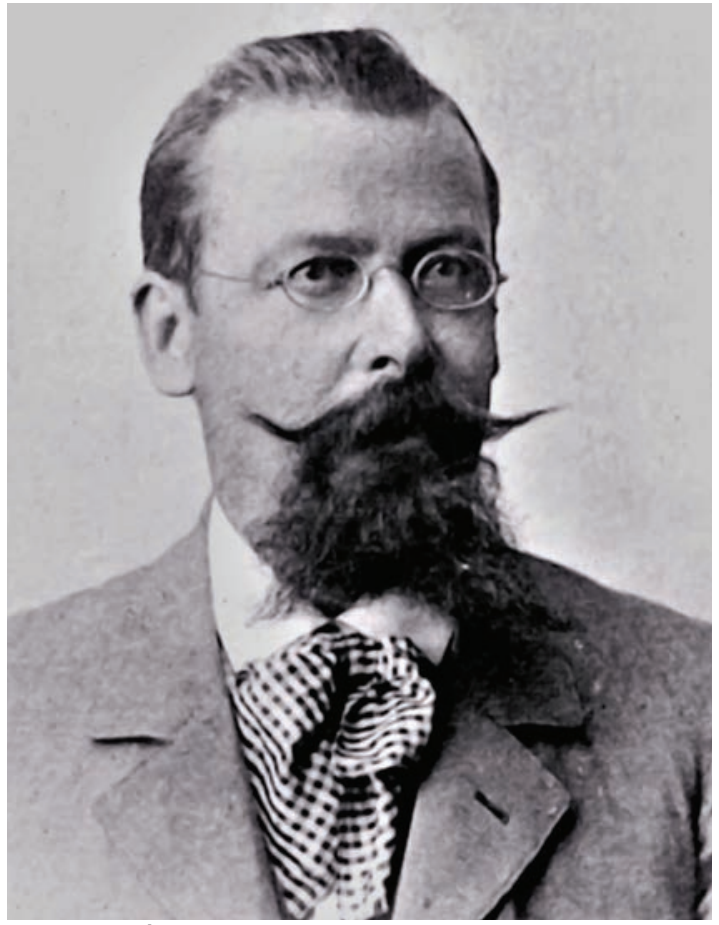

FIGURE 41. Émil August Goeldi. Unknwon photographer.

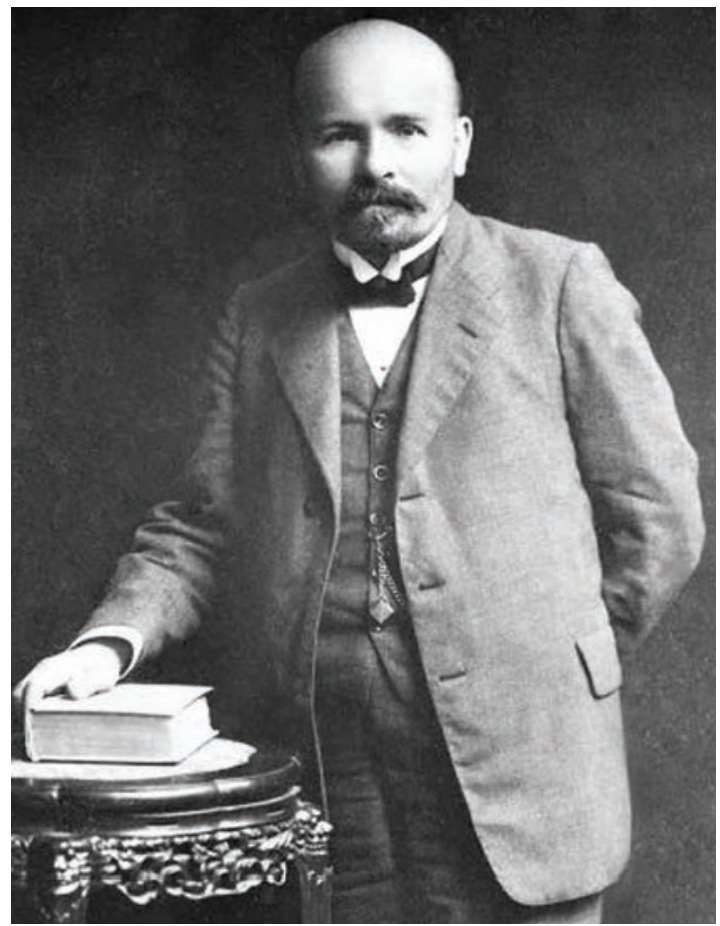

FIGURE 42. Jacques Huber (1867-1914). Unknown photographer. Archives of Rudolf Jenny. 


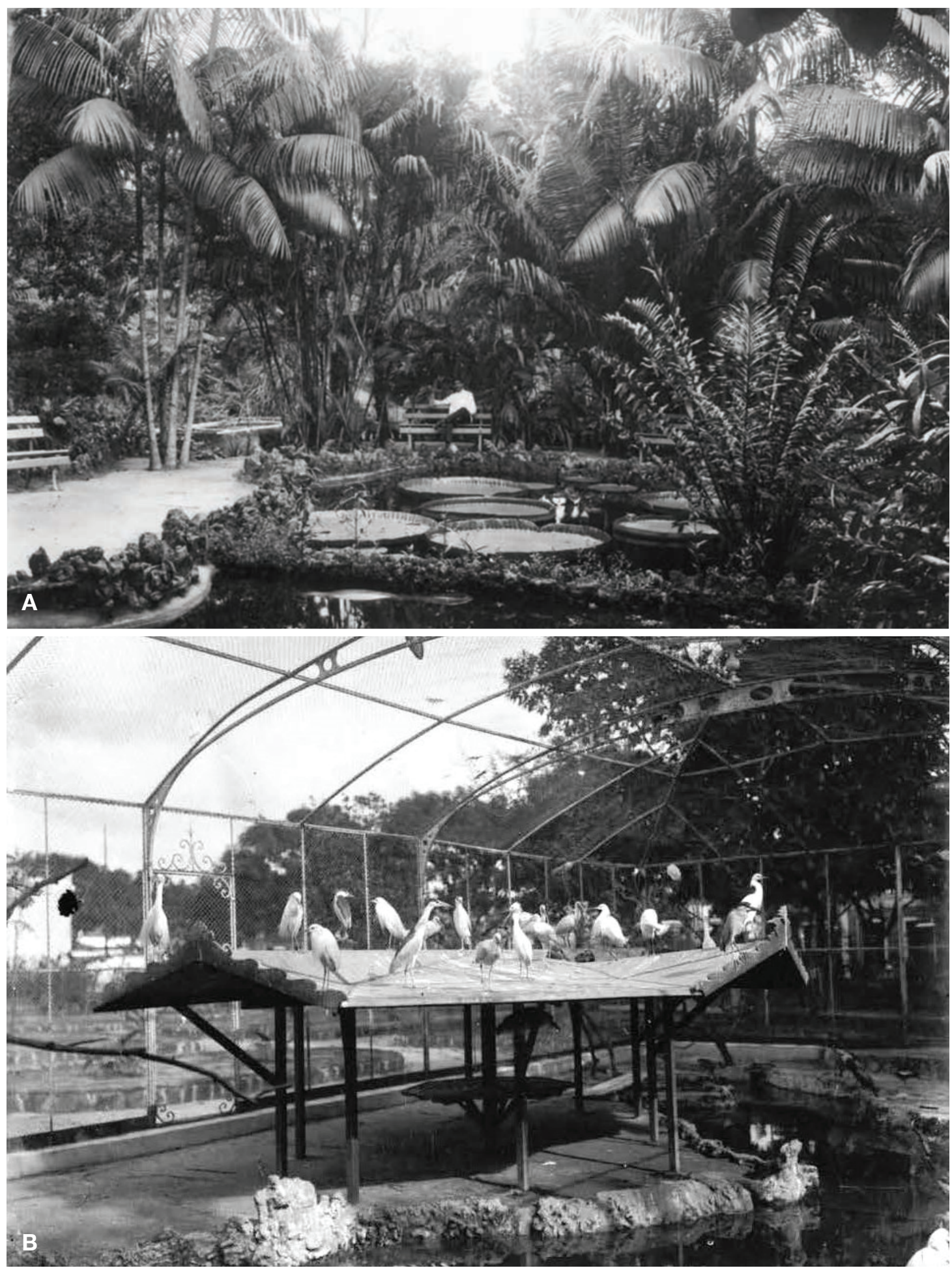

Figure 43. Museu Paraense Emilio Goeldi, 1901. A. Pond with Victoria regia. B. Cage with water birds. Unknown photographer: Arquivo Guilherme de La Penha. 


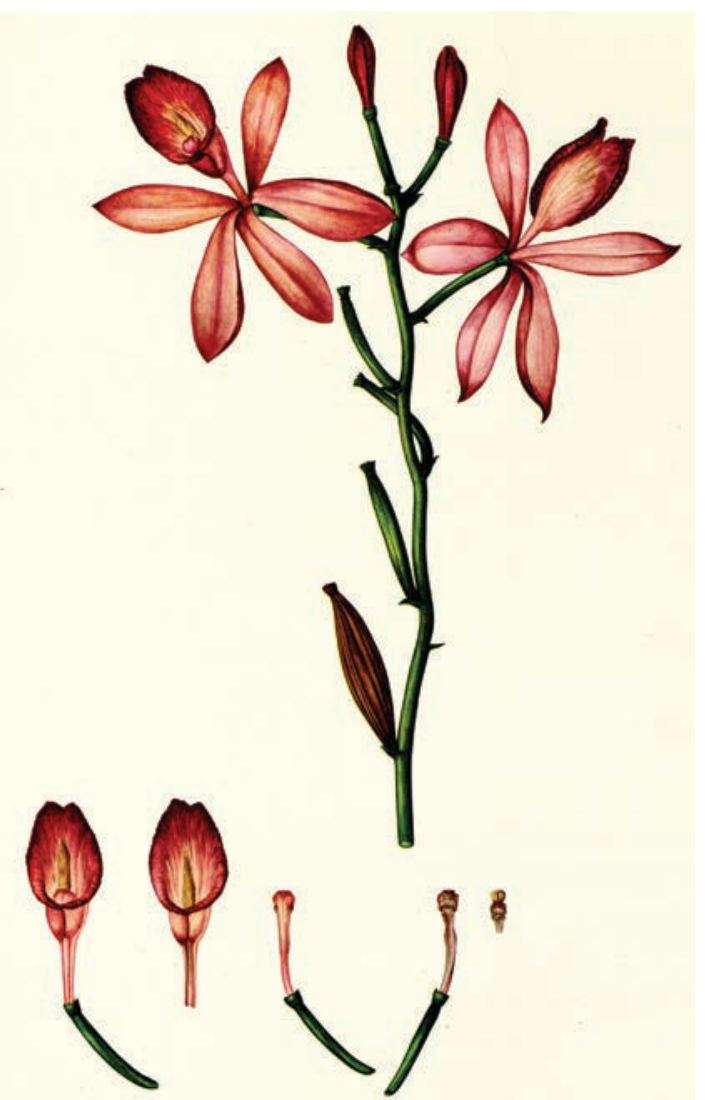

Figure 44. Epistephium duckei Huber. In: Mutis (19542010), Flora de la Real Expedición del Nuevo Reino de Granada, Vol. VII, Plate 9.

During his life, Huber was an active collaborator of activities intended to protect the tropical rain forests. He was the inspirer of a yearly «tree folks festival», and with the years became popularly known as «o amigo dos avores» ("friend of the trees"). Among his many botanical descriptions of new plants, Huber described five new orchid species: Epidendrum mapuerae Huber, Epistephium duckei Huber (Fig. 44), Epistephium petiolatum Huber, Vanilla duckei Huber, and Vanilla uncinata Huber ex Hoehne (Fig. 45).

Walter Adolpho Ducke (1876-1959) (Fig. 46) was born in Trieste, at the time part of the AustroHungarian Empire. The son of an engineer, he lost his father at young age, which led him to emigrate to Brazil, settling for a time in São Paulo. After returning to Europe, he began studies in entomology working under the direction of Heinrich Friese (1860-1948), recognized as the leading authority in Hymenoptera. In

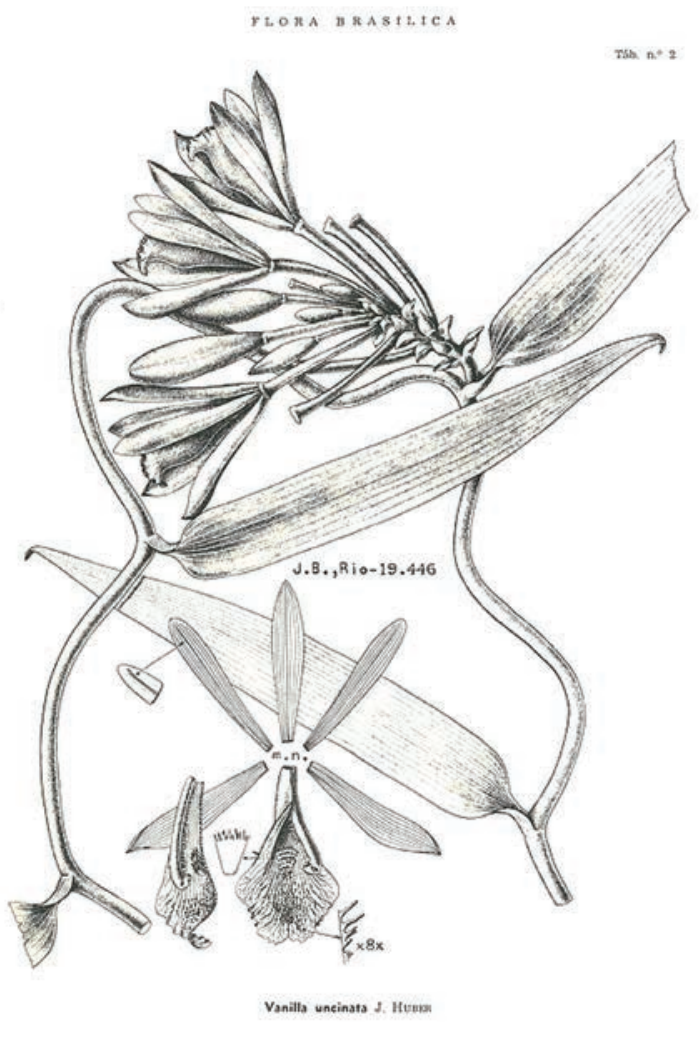

FIgure 45. Vanilla uncinata Huber. In F.C. Hoehne, Flora Brasilica: plate 2 .

1899, Ducke was engaged by Emilio Goeldi to take a position as entomologist and assistant in the Zoological Department at the Museu Paraense, where he would stay for almost 20 years. He began taking an interest in botany under Jacques Huber's influence, who had succeeded Goeldi at the direction of the Museum. Among the collections during his first excursion to Magazao, in the Federal Territory of Amapá (1900), we find already - besides numerous entomological specimens - some herbarium sheets collected as a result of Huber's encouragement.

Well trained, after the death of his adviser he dedicated himself entirely to botany, working almost exclusively on Amazonian species, especially on the difficult tree flora and particularly the Leguminosae. He once remarked that it was appropriate for a man of his height (about 2 meters) to be dedicated to the study of tall trees (Archer 1962). 


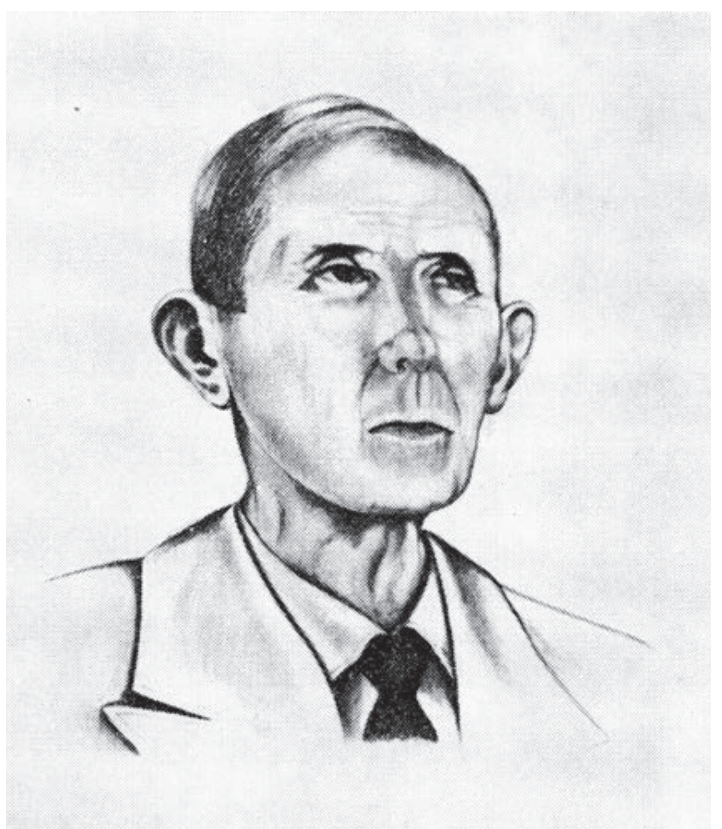

Figure 46. Walter Adolpho Ducke (1876-1959). Portrait sketch, unknown author. Archives of Rudolf Jenny.

"The difficulties of collection, irregular flowering, fertile samples difficult to spot due to the height of the trees, problems of access and establishment at remote regions, were some of the obstacles to overcome. Ducke managed all these problems, creating the current techniques for plant collection and monitoring tree phenology. He located the trees in bloom by observing the forest floor in search of fallen flowers or listening to the sounds of animals that gather nectar or fruits. He also instructed and trained local people in techniques for climbing trees and collecting botanical samples. When additional botanical material was necessary, he used to mark and make repeated trips to visit particular trees. Through repeated visits to those remote locations, he became an expert on the region and on the local and regional flora. His persistence, patience, and meticulousness established him as one of the most respected investigators of the Amazon flora until the present day" (dos Santos 2016).

Several of Huber's descriptions of new orchid species were based on collections by Ducke and published in 1909 as Plantae Duckeanae austro-guyanenses, a work that included all those botanical specimens collected by Ducke between 1902 and 1907 and determined by Jacques Huber. An important number of orchids is included in this publication, including (according to the original nomenclature) Habenaria pauciflora Rchb.f., Vanilla duckei Huber, Spiranthes acaulis Cogn., Galeandra devoniana Schomb., G. juncea Lindl., Epidendrum caespitosum Barb.Rodr., E. mapurae Huber, Sobralia liliastrum Lindl., and Cyrtipodium cristatum Lindl. (Ducke \& Huber 1909).

As mentioned above, during his first years, Ducke's dedicated his main efforts to entomological collections, and only in second place to botany. However, this tendency to botany would, over the years and influenced by the growing relationship with Huber, lead to a complete transformation in Ducke's interests and collecting activities. In the years after Huber's death, Ducke's bibliography contains only botanical works. In 1915, he began the publication of his Plantes nouvelles ou peu connues de la region Amazonienne, which he continued until 1939.

"[Ducke] published 180 papers and monographs. Of this total, two thirds on botanical subjects. 1050 new entities were added to scientific knowledge: 900 new species, 50 genus, 80 varieties and almost 20 forms. His field trips covered practically all of the Amazonian region, with repeated excursions to the same place. [...] he colaborated with others institutions such as Jardim Botãnico (Rio de Janeiro) and Instituto Agronômico do Norte (Belém)" (Egler 1963).

In 1914, the Museu Paraense's golden era had come to its end and the institution went into a period of progressive decadence. The scientific staff, thrown into disarray by the death or retirement of the best part of its members, could not be renewed, in part by the conditions imposed by the world war, which led to Brazil breaking up relations with Germany and Austria, the museum's main source of scientists. In addition, the lack of financial resources made the daily work increasingly difficult. The museum had been reorganized in the midst of the rubber boom, during which it counted with generous official support. The war, and the collapse of the market for natural rubber left the state of Pará without resources to properly maintain the museum. Ducke left Belém in 1918 and moved to Rio de Janeiro, where he accepted a position in the Department of Botany and Plant Physiology of the city's Botanical Garden.

From Rio de Janeiro, Ducke organized over the next 25 years numerous excursions to the Amazon, spending long periods in Manaus, which became his 


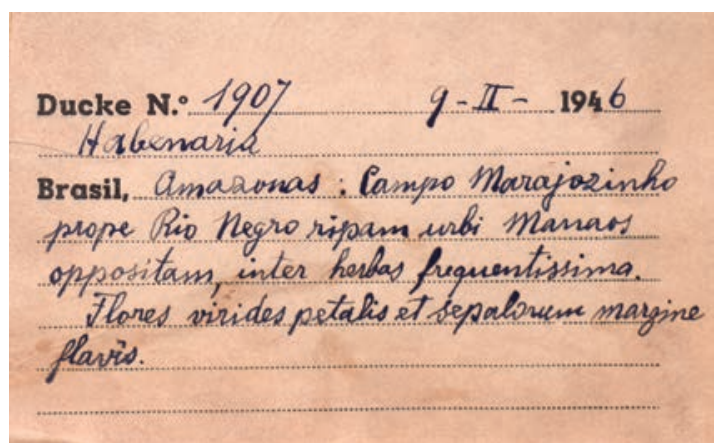

FIgURE 47. Ducke herbarium label of a specimen of Habenaria sp. Oakes Ames Herbarium \# 01946195.

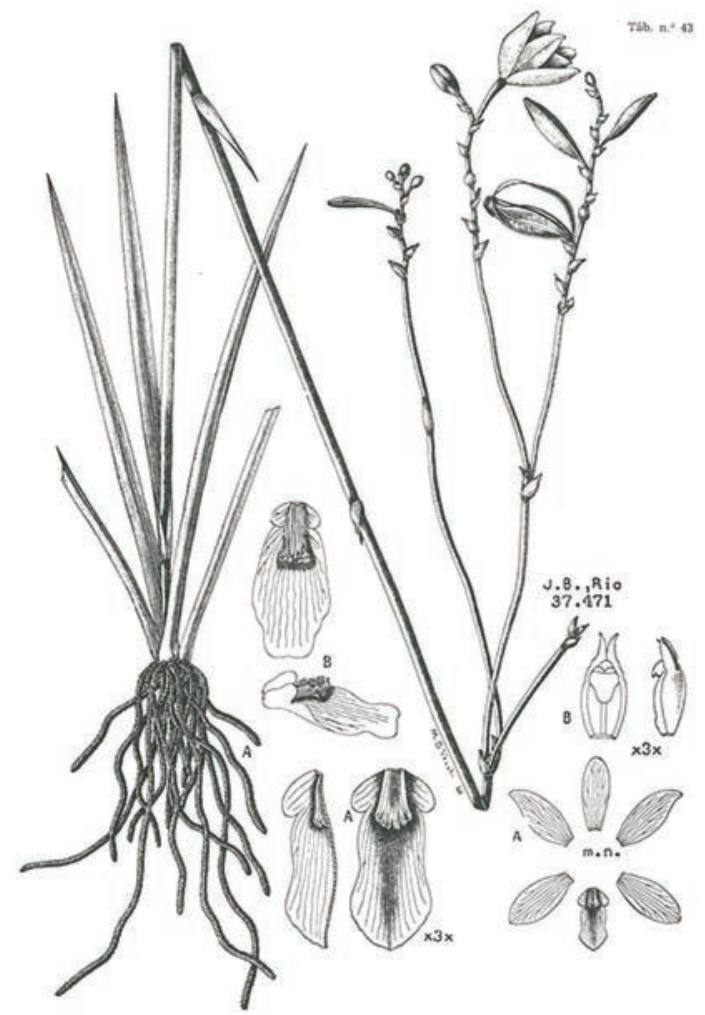

Figure 48. Duckeella adolphii Porto \& Brade. In Hoehne, Flora Brasilica, plate 43.

support and encouragement from the Council.

Adolpho Ducke died in Fortaleza, State of Ceará in 5 January, 1959. He was honored by Porto and Brade by naming a new orchid genus after him: Duckeella Porto $\&$ Brade and two new orchid species, Duckeella adolphi Porto \& Brade (Fig. 48) and Epidendrum duckei Porto $\&$ Brade. Huber named in his honor Epistephium duckei Huber (Fig. 53, 54) and Vanilla duckei Huber, and
Horta did the same with Brassavola duckeana Horta. Rudolf Schlechter added Habenaria duckeana Schltr. (from a collection by Kuhlmann) and Triphora duckei Schltr. (from a collection by Ducke) (Schlechter 1926a), Sampaio contributed Octomeria duckei A.Samp. and Hoehne Palmorchis duckei Hoehne. Pessoa and Alves honored him in Stelis duckei E.M.Pessoa \& M.Alves.

Arellano and coauthors (2019) consider Walter Adolpho Ducke "the most legendary individual in the Amazon basin."

Philipp von Luetzelburg (1880-1948; collected 1910-1936)

A controversial figure, Philipp von Luetzelburg (1880-1948) (Fig. 49) was a German botanist and traveller, who made his name as collector of plants in the Amazon River basin and northern Brazil. Of aristocratic origin, Luetzelburg went to school in Augsburg and Memmingen and then began an apprenticeship in pharmacy which brought him to Ottobeuren, Reichshofen, Basel, Cologne and Murnau. After receving his title in Pharmacy from the University of Munich in 1906, he was named Assistant at the University's Institute of Plant Physiology and received in 1909 his $\mathrm{Ph} . \mathrm{D}$.

The turning point in Luetzelburg's career came in 1910, when he was commissioned by the Bavarian Academy of Sciences to travel to Brazil and collect plants in the region of Rio de Janeiro. It was love at first sight: in 1912 Luetzelburg decided to stay in Brazil, and would live in this country for the next 25 years, with an interval in Germany from 1922 to 1926 . He was named Professor of Botany at the Agricultural Institute in São Bento, Bahia, and held a series of positions as adviser to the Brazilian Government during the next years. During World War I he lost all of his Brazilian posts, was however still allowed to travel throughout the country. He returned to his office immediately after the end of the war. Shortly thereafter, in 1921, Rudolf Schlechter described two new species of orchids, which he named after him: Habenaria luetzelburgii (Fig. 50) and Pelexia luetzelburgii (Schlechter 1921: 268-270). Two years later, in 1923, Sandt described Epidendrum luetzelburgii Sandt ex Luetzelburg. When Luetzelburg returned to Germany he carried with him an important botanical collection of over 28,000 specimens, many of which were described as new to science in Robert 


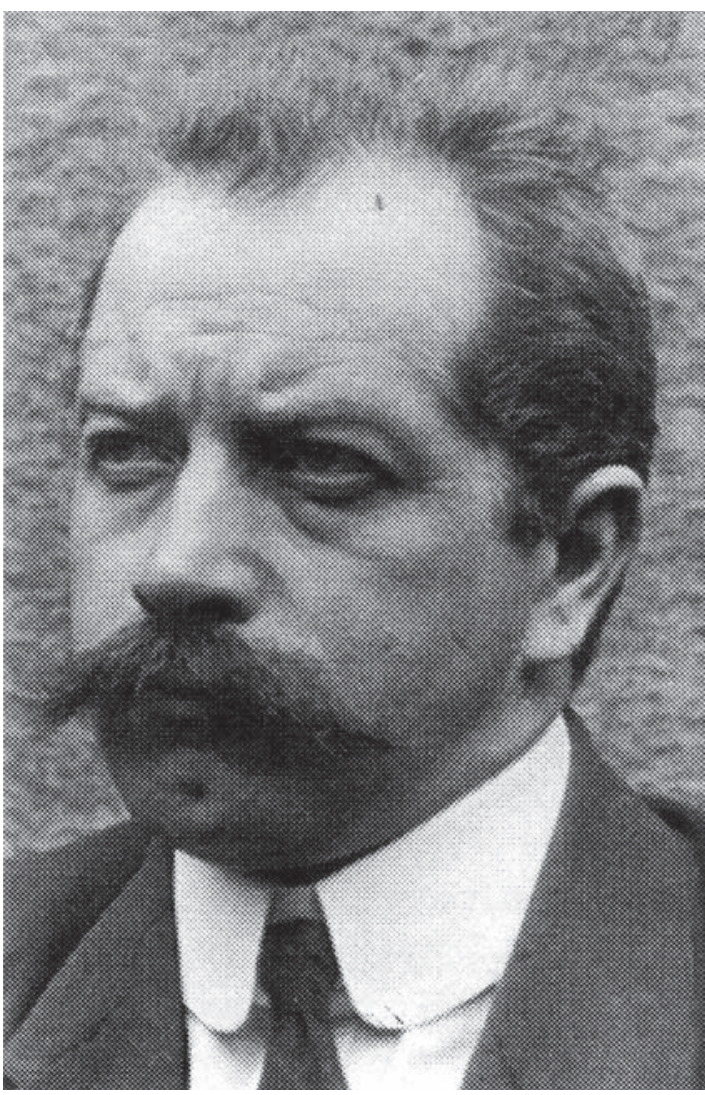

FIGURE 49. Philipp von Luetzelburg (1880-1948). Archives of Rudolf Jenny.

Pilger's (1921-1927) series of Plantae Luetzelburgianae brasilienses. However, no orchids were mentioned in this work.

Luetzelburg returned in 1926 to Brazil and in 1928 took part in a new expedition organized by Colonel Cândido Mariano da Silva Rondon, this time to the regions on the border with Colombia, Guyana and Venezuela, including the table mountains of Roraima. During the expedition, which had as main objective the cartographic survey of the Brazilian borders, Luetzelburg collected over 9,000 botanical specimens. Further expeditions, under contract with the Brazilian government, were organized by Luetzelburg in 1930 to British Guiana and from 1933 to 1937 to the savannas of Ceará, during which further botanical collections were made. Most of his botanical collections were sent to the State Herbarium in Munich (formerly Royal Herbarium of Munich), were several orchid specimens collected by him are kept (Fig. 50).

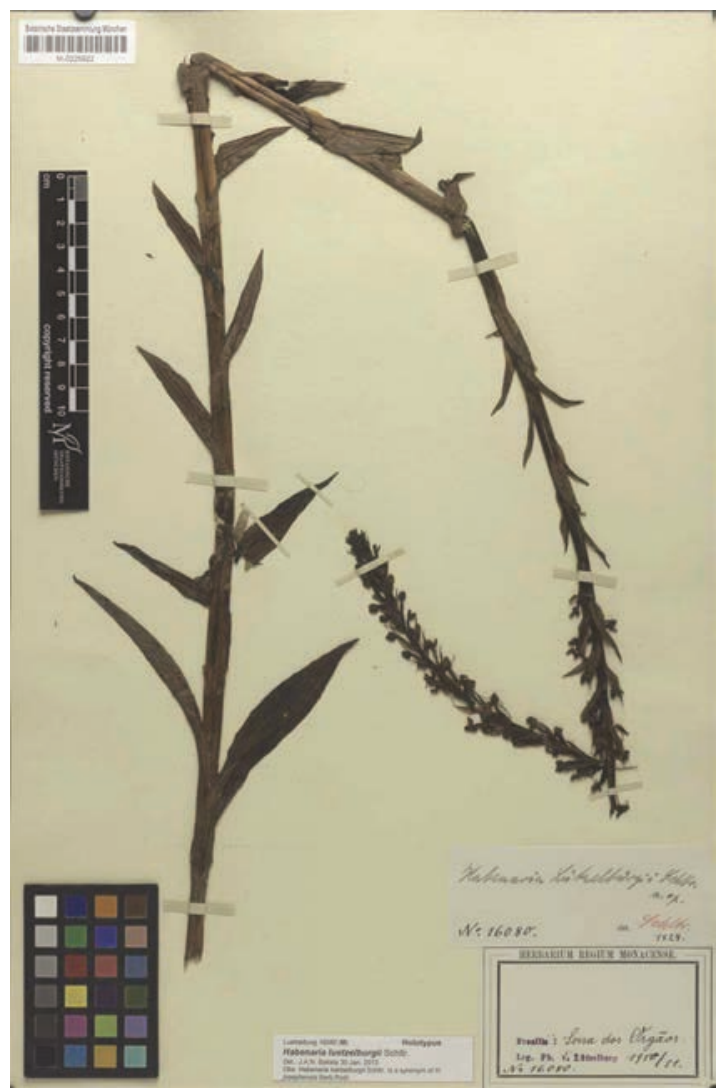

Figure 50. Habenaria luetzelburgii Schltr., holotype. State Herbarium Munich, \# 16080.

After marrying Maria Naessl in Río de Janeiro in 1936, his wife's health problems forced him to return to Germany in 1938. Once there, he soon made contact with Heinrich Himmler, the infamous leader of the Schutzstaffel (SS), who was a cousin of his wife. Through Himmler's mediation he was appointed as Director of the Botany Departement of the "Ahnenerbe", a think tank that operated in Nazi Germany between 1935 and 1945 that had been established by Himmler as an appendage of the SS devoted to promoting the racial doctrines embraced by Adolf Hitler and his governing Nazi Party. His position in the "Ahnenerbe" was a severe blow for his international reputation. Adolpho Ducke published in 1945 a paper with the title: Um pseudobotânico Nazi no Brazil. Ph. von Luetzelburg e sua conferencia sobre a fitogeografia de Amazonia, a critical review of a paper on the phytogeography of the Amazon region published by Luetzelburg in 1939 


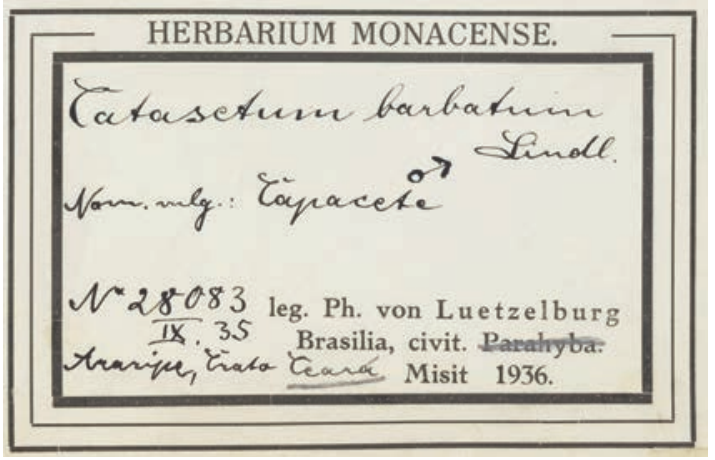

Figure 51. Luetzelburg herbarium label of Catasetum barbatum. New York Botanical Garden, \# 00547417.

(Ducke 1945). Ducke reproached him for a deficient preparation of his botanical specimens and for incorrect determinations (Fig. 51). He was however especially angry at Luetzelburg for having brought all of his collections to Germany, without leaving duplicates in Brazilian herbaria.

Luetzelburg was promoted to «SS-Sturmbannfuhrer» and in 1943 to «SS-Obersturmbannführer» (equivalent, respectively, to the ranks of major and lieutenant colonel in the German Army), and was awarded in 1944 one of the SS's highest honors: the «Totenkopfring» (Death's head ring). During his time of service with the "Ahnenerbe» he worked mainly with vegetal poisons and medicinal plants of the South American natives. He had occasional contact with the infamous SS-Physician Sigmund Rascher, known for his experiments with human beings.

A long manuscript about the history of the botanical exploration of Brazil, prepared by Luetzelburg, was lost during the turmoils at the end of the war. $\mathrm{He}$ retired with his wife to his native Bavaria, where he died in 1948. The genus Luetzelburgia Harms from the Fabaceae was named in his honor.

The State Herbarium in Munich, besides the already mentioned holotype of Habenaria luetzelburgii, holds a number of other orchid specimens which he collected in Brazil, among them a syntype of Pelexia luetzelburgii Schltr., a new orchid species described by Schlechter as Laelia bahiensis, and specimens of Cranichis candida (Barb.Rodr.) Cogn., Habenaria hamata Barb.Rodr., Isochilus linearis (Jacq.) R.Br., Prescottia stachyodes (Sw.) Lindl., Sacoila lanceolata (Aubl.) Garay, Stelis grandiflora Lindl., and several undetermined specimens of Epidendrum and Sobralia.

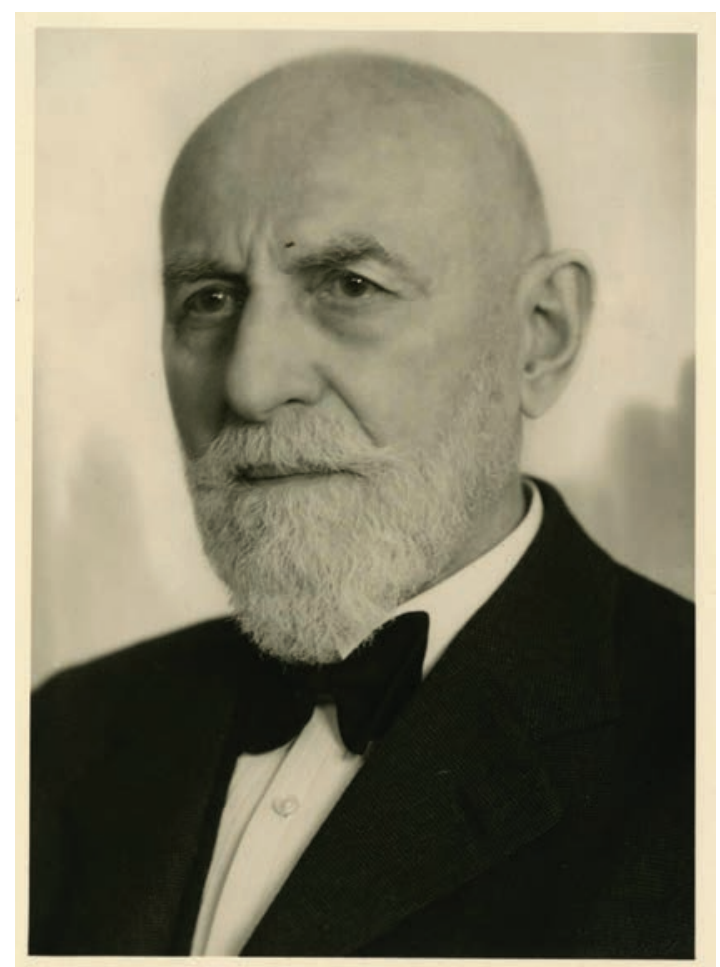

Figure 52. Leo Zehntner (1864-1961). Archives of Rudolf Jenny.

Leo Zehntner (1864-1961; collected 1906-1918)

In Luetzelburg's botanical collection at the Herbarium in Munich we find a specimen with the imprint "Mis[cellaneous]. Ph. V. Luetzelburg", which is the holotype for a new orchid species described by Schlechter in 1925 and named in honor of Leo Zehntner (1864-1961) (Fig. 52), a Swiss naturalist who collected plants in Bahia around 1912, coinciding with Luetzelburg at the Agricultural Institute, where Zehntner was Director and Luetzelburg Professor in Botany.

Campylocentrum zehntneri (Fig. 53) was part of a botanical collection made by Zehntner in the years from 1906 to 1918, when he resided in Bahia after being invited by the Brazilian government to direct the Agricultural Institute at São Bento, a suburb of the city of Salvador de Bahía.

Zehntner was born in Reigodswil, a small village in the Swiss canton of Basel. He studied natural sciences in Basel and Bern and after graduating, worked since 1898 in Geneva as assistant to the renowned entomologist Henri Louis de Saussure. In 


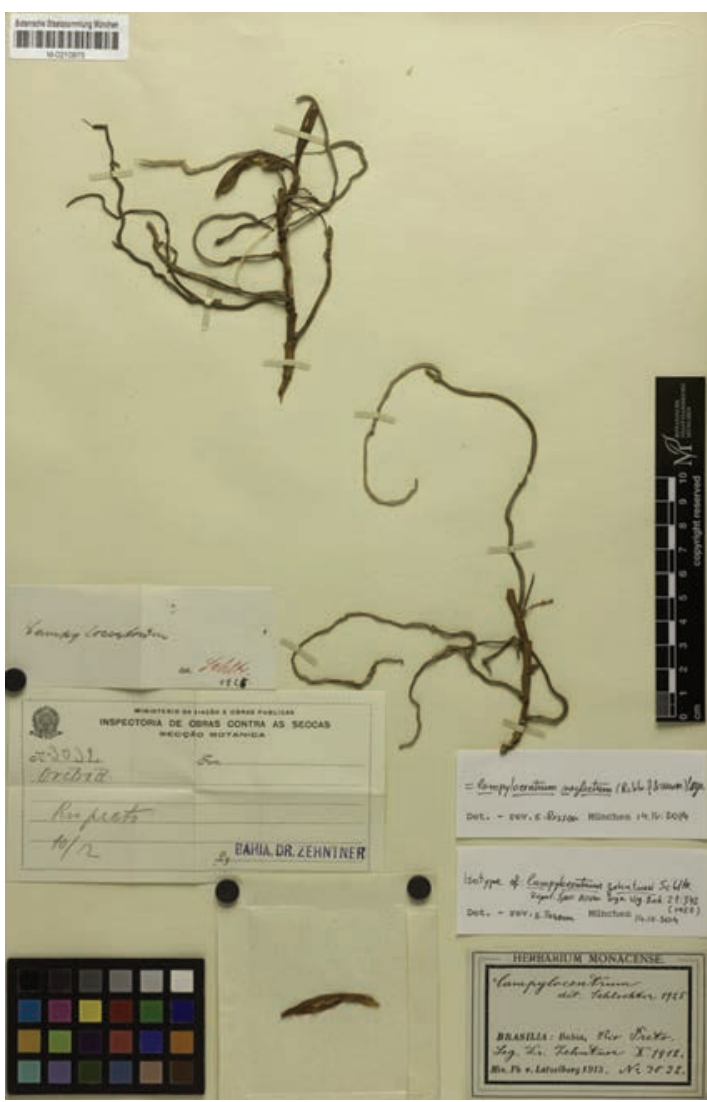

FIGURE 53. Campylocentrum zehntneri Schltr. Holotype in Luetzelburg's collection, \#3032.

1894, Zehntner was invited to work as zoologist at the Pasuruan inspection station in Java, to deal with pests that plagued sugar cane plantations in the region. In 1901, again in Java, he opened in Salatiga an inspection station for the cultivation of cacao.

Not long after having settled in Salatiga, Zehntner received the visit of Dr. Miguel Calmon, Secretary of Agriculture of the State of Bahía, in northeastern Brazil. Calmon offered Zehntner the direction of the Agricultural Institute in Bahía, which Zehntner accepted after a year-long struggle with himself, since he had established already strong social and professional relations In Java. However, Brazil was tempting and finally, in May of 1906, Zehntner assumed his post in Bahía.

Zehntner served at the Institute in Bahía until 1918, a time during which, aside from his new orchid specimen, he discovered eight new species of rubbertrees and five new species of cacti.
After returning to Europe in 1920, Zehntner continued his scientific activities, but took part in local politics and was active in the improvement of living conditions in his hometown. From 1926 to 1941, he served as mayor of the town of Reigoldswil (after Schmassmann 1939, 1961).

The Guianas. The Guianas are on the Guiana shield, a geographic formation along the northern South American coast. Most of the region consists of flatlands, drained by important rivers flowing into the Atlantic, or in a few cases into the Amazon. The Guiana shield (Fig. 54) extends roughly from the Atlantic Ocean to the east, the mighty Orinoco River to the north and west, the Rio Negro to the southwest and to the south the Amazon. From a historical point of view, the territory consists of the former British, Dutch and French Guyana, colonies that in the $20^{\text {th }}$ century gave way to the independent republics of Guyana and Suriname, and to French Guiana (or Guyane), today an overseas region and department of the French Republic. From a geographical viewpoint, two other territories should be added to the Guianas in a broad sense: Spanish Guiana, the present southeastern Venezuela; and Portuguese Guiana, later the Brazilian Guiana and today the Brazilian state of Amatá.

The Guianas consist of wetlands along the Atlantic coast, with the ground slowly rising to the South and East, until reaching its highest peaks, in Suriname the Julianatop, with $1230 \mathrm{~m}$ and in French Guiana the Bellevue d'Inini, at $861 \mathrm{~m}$. British Guiana is limited at the south for the mythical table mountains of Roraima, with Mount Roraima as its highest peak with 2727 $\mathrm{m}$. The total area of the Guianas is of some 460,000 sq. $\mathrm{km}$, approximately the same area as the whole of Central America.

The botanical exploration of the Guianas is of especial interest due to the special position of these territories during the $16^{\text {th }}, 17^{\text {th }}$ and $18^{\text {th }}$ centuries. While Spanish and Portuguese South America were jealously protected by their motherlands, and no foreigners were allowed into these colonies, the Guianas were the only territories were European naturalists, travellers and other adventurers could roam at their will. Thus, as we have seen (Ossenbach 2020), the number of explorers of the Guianas during these three centuries was enormous in relation to the small size of their territories. 


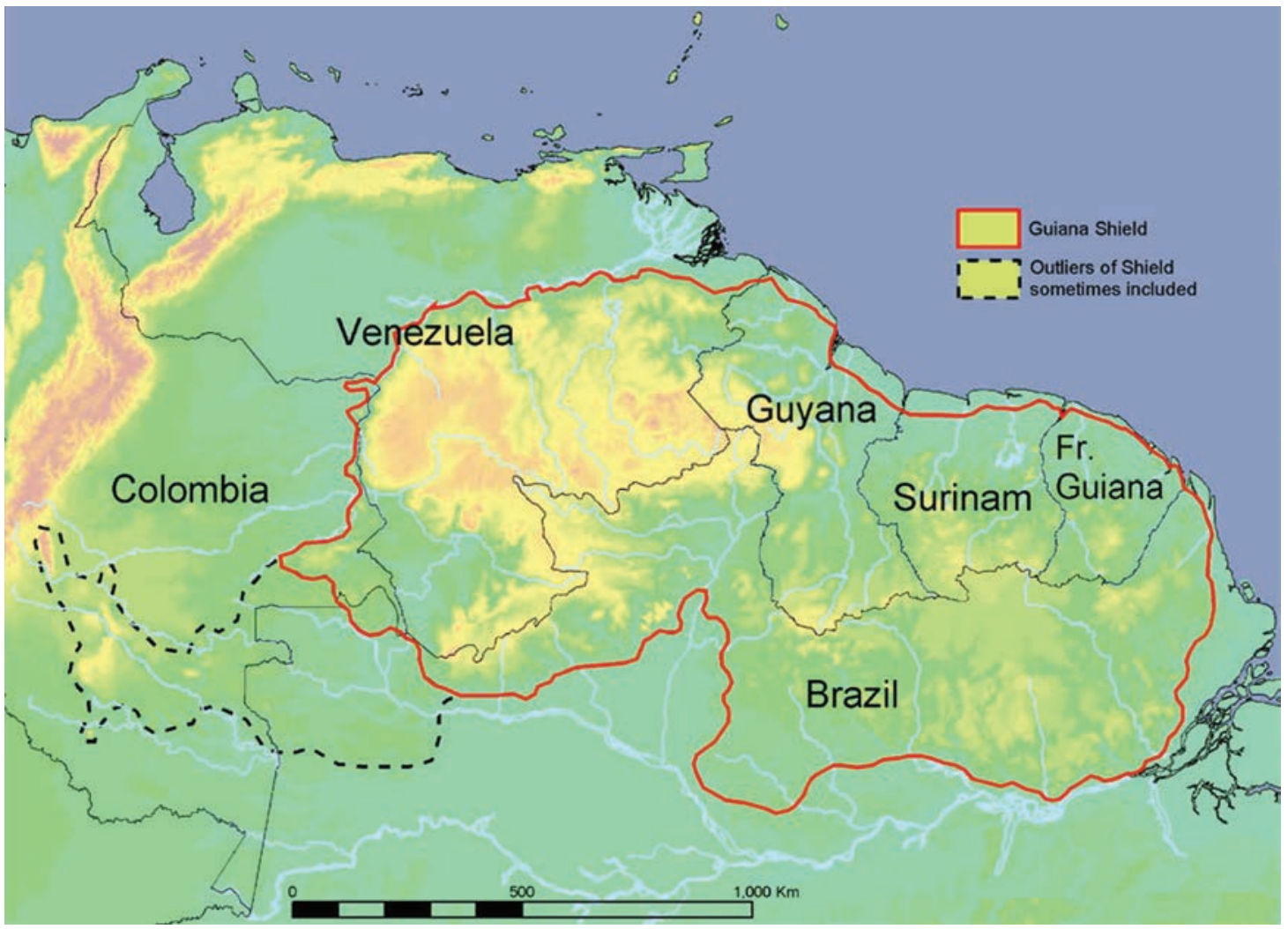

FigurE 54. Map of the Guiana shield. By Tom Hollowell, NMNH Informatics.

This situation took a reverse turn when Portugal, in 1808, opened the doors of Brazil to all foreigners, and the new South American republics followed suit after gaining independence during the period of 1810 to 1825. Although botanical collecting continued, the number of collections in the Guianas decreased significantly, especially during the second half of the $19^{\text {th }}$ century. Other, barely explored lands, held now the attention of voyagers and botanists.

In 1939, a volume of bound herbarium sheets was found at the University of Leiden, prepared by wellknown botanist Paul Hermann (1646-1695). The plants had been collected in Suriname in 1687 by a certain Hendrik Meyer and where integrated into Hermann's herbarium, where they lay during centuries, confused with Hermann's collections of plants from Ceylon. Among the plants from Hermann and Meyer's Suriname herbarium we find a sheet containing a specimen of Erycina pusilla (L.) N.H.Williams \& W.W.Chase, in all probability the first herbarium specimen prepared from an orchid from the Guianas (Ossenbach, 2020). "It must be understood that, true to the spirit the Netherlands' Golden Age of seaborne mercantilism, Suriname itself was administered as a business enterprise. In 1684 the society of shareholders, each owning one third of the Suriname trade, consisted of the Dutch West India Company, the City of Amsterdam, and the powerful family Van Aerssen van Sommelsdijk. A number of the directors of the Society of Suriname were also commissioners of the Amsterdam Hortus Medicus, the city's botanical garden. Consequently, plant exchanges between Suriname, the Dutch East Indies and Amsterdam were frequent, plantation owners (Fig. 55) acting often as patrons and sponsors for learned institutions and scientists. They provided not only specimens of tropical plants, but their plantation houses served often as headquarters for botanical and other scientific expeditions (DeFilipps 1992).

A few years later the German botanical and zoological illustrator Maria Sibylla Merian (16471717), the first female explorer of the American Tropics, illustrated the first orchid from the region, a beautiful 


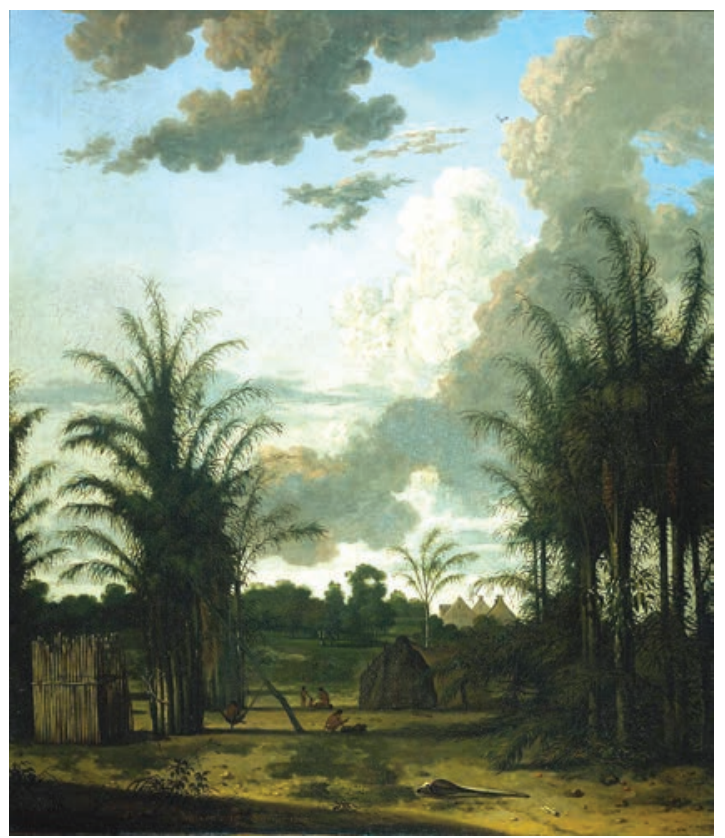

FiguRE 55. Plantation in Suriname, 1707. Oil on canvas by Dirk Valkenburg.

watercolor showing an arrangement of butterflies and caterpillars on a plant of Vanilla planifolia.

Pierre Barrère (1690-1755), who spent three years, from 1722 to 1725, in Cayenne, was the first explorer of French Guiana. He published two important works on the natural history of the colony, Essai sur Histoire Naturelle de la France Equinoxiale (1741) and Nouvelle Relation de la France Equinoxiale (1743). In his works, Barrère described 12 species of orchids, some of them yet undetermined.

The Swede Daniel Rolander (1725-1793), one of Linnaeus' "apostles", arrived in Suriname in 1754, and spent two years in the Dutch colony, sponsored by his countryman Carl Gustav Dahlberg (1721-1781), who also had botanical interests. Rolander left two manuscripts, Diarium Surinamicum (1754-1765) and Diarium Surinamense, quod sub itinere exotico conscripsit Daniel Rolander (published posthumously in 1811). In these works, Rolander named four different species of orchids collected by him in Suriname.

Known as the "founding father of ethnobotany in the Neotropics", Jean Baptiste Christophore Fusée Aublet (1720-1778), a skilled pharmacist with a great interest in botany, was accepted at the Jardin du Roi in Paris to complete his training as an "apothecaire- botaniste". He eventually accepted a position as Botanist in French Guiana at the invitation of the King of France in 1762, and stayed in the colony for the next two years, a time during which he dedicated every free moment he had to observing and collecting plants. With the results of his two years of collecting in French Guiana, Aublet published his monumental Histoire des plantes de la Guiane Françoise in 1775, in which over 30 species of Orchidaceae were described. Of these a remarkable amount, 12 in total were new to science.

Someone said of Louis-Claude Marie Richard (1754-1821), that "he had sucked botany with the milk". In 1780 the French Government sent to the French possessions in America a man capable of collecting plant species that could be useful. King Louis XVI gave personal instructions in this matter. Louis-Claude was chosen and travelled to Cayenne in July 1781, remaining there for eight years. Richard returned to France in 1789 with a large botanical collection, from which Kunth described the orchid genus Catasetum in 1822.

In 1790 Joseph Martin (?-ca. 1826) was appointed Director of the cultivation of spice plants and other exotics in the acclimatization garden at Cayenne (plantation La Gabrielle) in French Guiana. He held this post until 1802 (with a two-year interlude in France from 1796 to 1798) and during the last years at his post, he collected new orchid species that were new to science. Martin was one of Joséphine Bonaparte's most assiduous plant suppliers for her Château de Malmaison, near Paris.

Georg Friedrich Wilhelm Meyer (1782-1856), a professor at the University of Goettingen, became interested in tropical botany, especially after he had the opportunity to purchase the herbarium of Ernst Carl Rodschied (?-1796). Rodschied, a German physician and botanist, emigrated to Essequibo (a part of Dutch Guiana) in 1790 in the service of the Dutch West-India Company and lived there until his death in 1796. Rodschied wrote several small works about climate, social circumstances, and health problems of the population of the colony, and made frequent botanical excursions along the rivers Demerara and Essequibo. Based on Rodschied's collections, in 1818 Meyer published an important work: Primitiae Florae Essequeboensis adjectis descriptionibus centum circiter stirpium novarum, observationibusque criticis, 


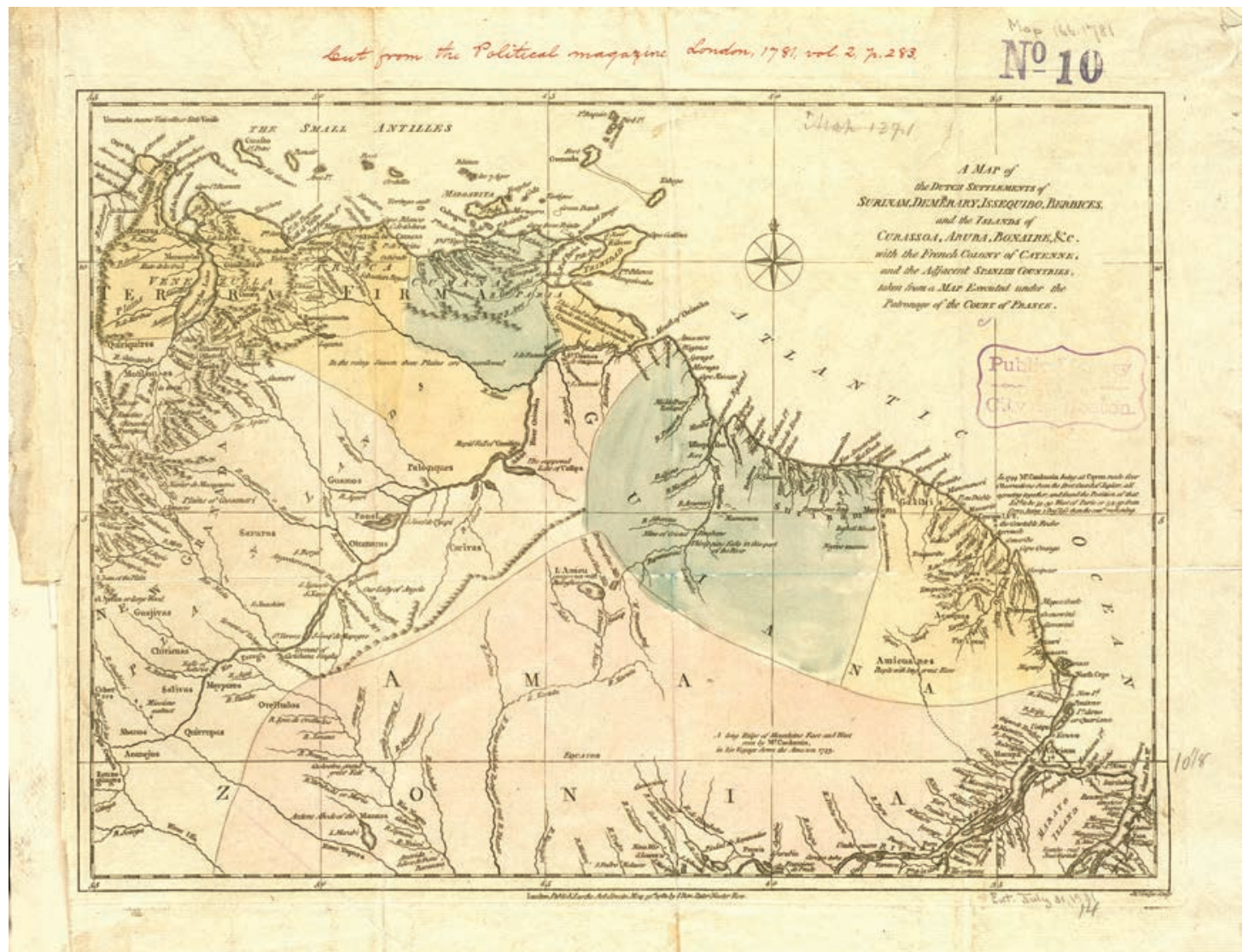

FiguRE 56. A map of the Dutch settlements of Surinam, Demerary, Issequibo, Berbices, and the islands of Curassoa, Aruba,

Bonaire, \&c., with the French colony of Cayenne, 1781. By John Lodge.

a precursor to a flora of the colony. In this work, Meyer determined two new orchid species: Epidendrum flexuosum and Dimerandra emarginata.

At the end of the $18^{\text {th }}$ century, France and the Netherlands shared a hegemonic position in the territory of the Guianas. Great Britain only came into the region at the turn of the century, after occupying in 1796 the Dutch colonies of Essequibo, Berbice and Demerara, which were officially ceded to the British in 1812 and consolidated into the colony of British Guiana, in 1831 (Fig. 56). It is only in the period of 1820-1840 that we find the first British botanists and collectors in the region, with outstanding figures as John Henry Lance and Robert Schomburgk.

British and Dutch Guiana are today independent republics under the names of Guyana and Suriname respectively, while French Guiana is today known as Guyane Française or simply Guyane, an Overseas Department of the French Republic.
In 1818, three important plant collectors arrived in French Guiana and Suriname, respectively: the French Pierre Antoine Poiteau (1766-1854) together with the Swiss Georges Guerrard Samuel Perrottet (1793-1870) in Cayenne, and the German Friedrich Wilhelm Rudolf Hostmann (1794-1864), in Paramaribo. Poiteau and Perrottet made important collections of orchids in the colony, among them several new species. Hostmann, who was born in Hildesheim and studied medicine at the University of Göttigen, came in 1818 to Paramaribo, where he established a very lucrative private clinic, and where he would live for the rest of his life. In 1824, Hostmann sent a herbarium to his teacher Ernst Heinrich Friedrich Meyer (not to be confused with the Georg Friedrich Wilhelm Meyer named above) at Gottingen. Meyer published his Plantarum Surinamensium in 1825, based on Hostmann's collections. Several new orchid species were described in this work. Years later, Rolfe would dedicate Vanilla hostmanni to its collector. 

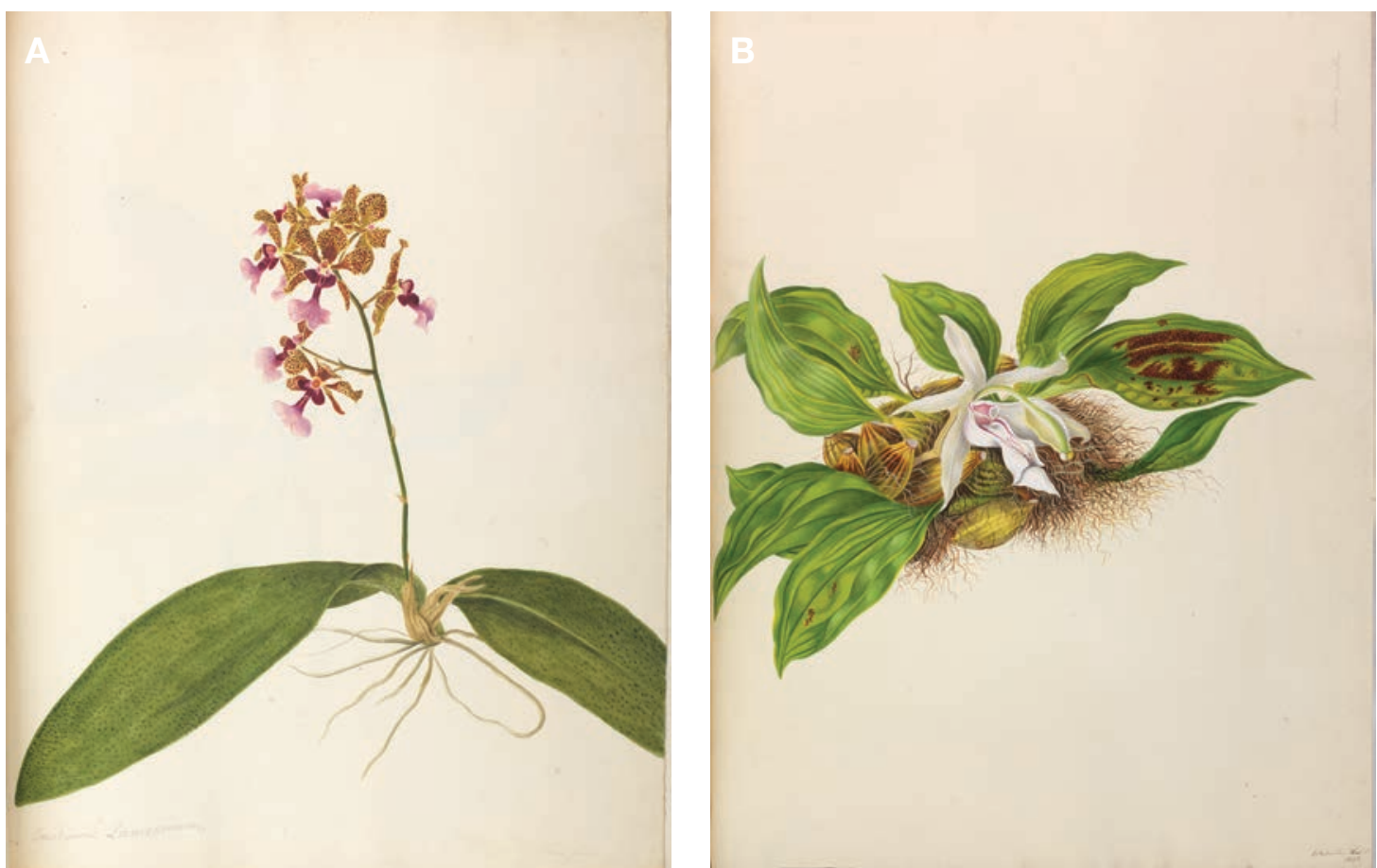

FIGURE 57. Illustrations from Surinam orchids, Etc. from Nature. A, Oncidium lanceanum Lindl.: plate 125, by J.H. Lance. B, Stanhopea grandiflora (Loddiges) Lindl.: plate 055, by Gerrit Schouten. With permission of the Lindley Library, R.H.S.

During the rest of his life, Hostmann continued botanizing, and sent large collections of plants to Sir William Hooker.

John Henry Lance (1793-1878), a British barrister, spent a ten year term in Surinam, as Judge appointed to the 'Mixed Court' in Paramaribo, created to supervise the compliance of the Dutch authorities of a treaty signed between the Netherlands and England in 1818, which prohibited the slave trade in the Dutch colonies. During his term in Paramaribo, Lance, a friend of Bateman and Lindley, collected a number of new orchid species, a few of which such as Oncidium lanceanum and Brassia lanceana, were described by Lindley in his honor. However, more important seems to be his collection of watercolors depicting plants from Surinam, many of them orchids. Some of these were painted by himself, and others by the Surinamese artist Gerrit Schouten and are contained in two bound manuscript volumes with the title Surinam orchids, Etc. from Nature, today fortunately available at the Lindley Library of the Royal Horticultural Society (Figs. 57A-B). These illustrations have remained hitherto unpublished (Ossenbach 2020b).
Henrik Charles Focke (1802-1856) was a Dutch lawyer and botanist, born of a black mother and a white father. He received his education in the Netherlands at Utrecht, where he received his Ph.D. in 1827. He collected plants in Suriname (to where he had moved in 1834), British Guiana and during a short excursion also in Peru, among them a new species of orchid, Pleurothallis fockei named in his honor by Lindley. In 1850 he published an important work, Enumeratio diagnostica Orchidearum quarundam Surinamensium, one of the first to be published specifically about orchids in the Guianas. Here, Focke described a number of new orchid species, two of which, Brassavola surinamensis and Masdevallia surinamensis were named by him in honor of his adopted country.

Robert Hermann Schomburgk (1804-1865) was born in Prussian Saxony, son of a Protestant Minister. He began with diverse commercial enterprises in 1828 which eventually led to his financial ruin. In 1839, he surveyed the island of Anegada, in the Virgin Islands, at his own expense and, after reporting the results of this adventure to the Royal Geographical Society was entrusted with conducting an expedition of exploration 


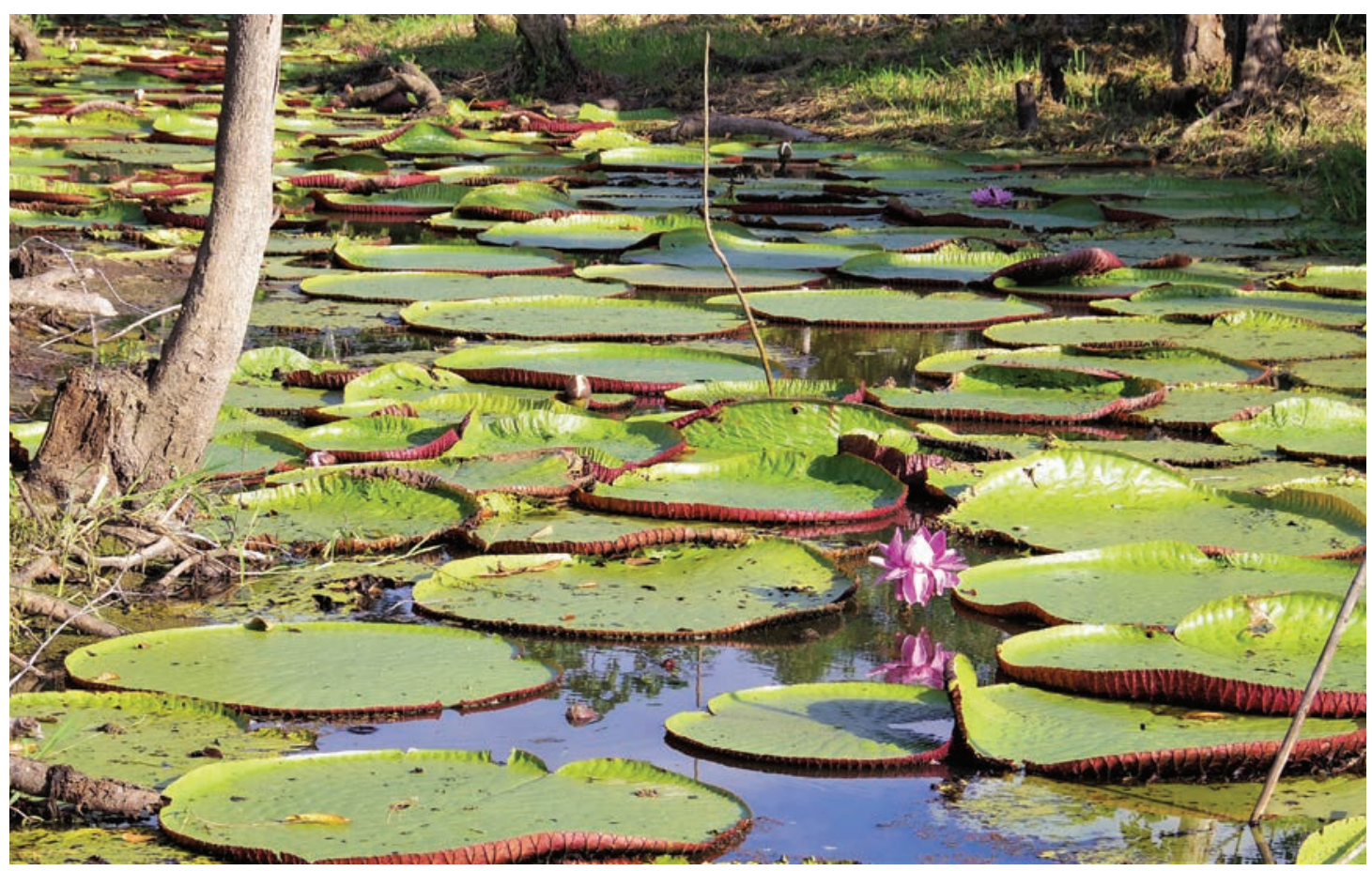

Figure 58. Victoria regia Lindl. Photograph by P. Casasa and C. Ossenbach.

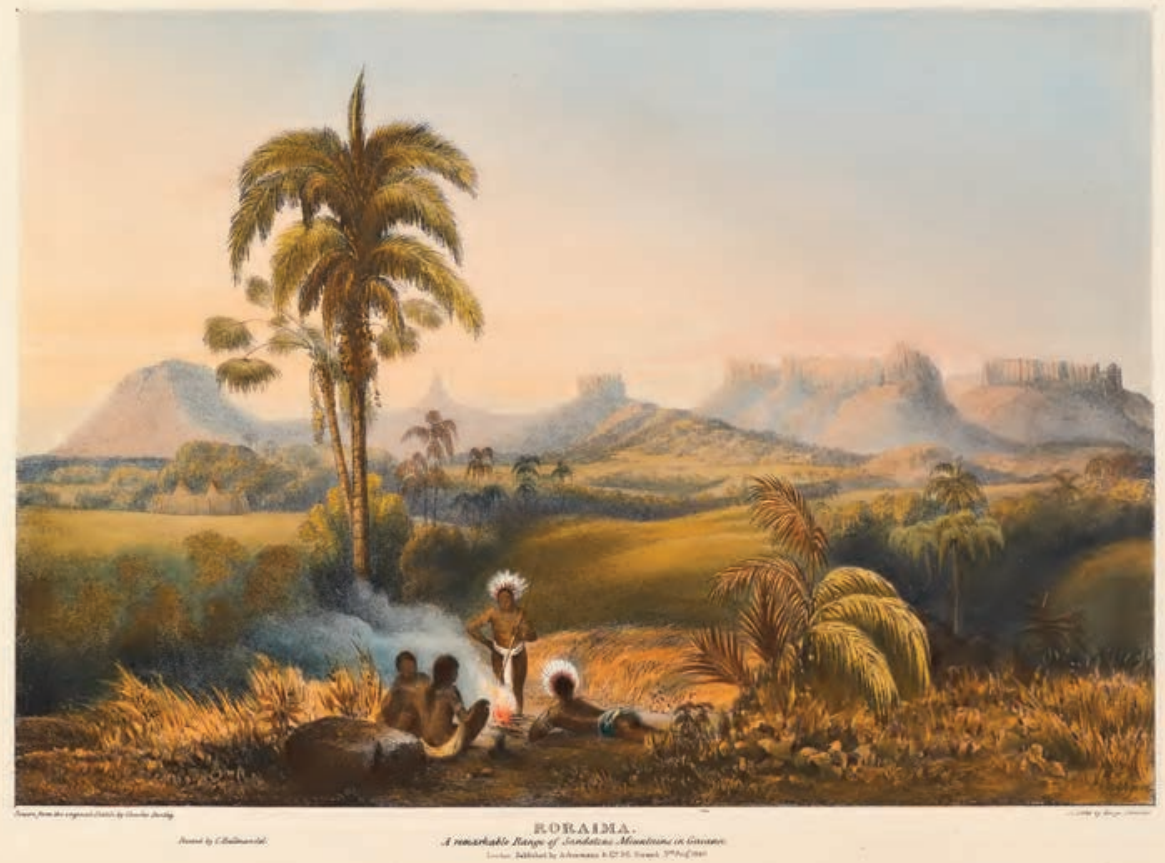

FiguRE 59. Table mountains of Roraima. By Charles Bentley in Schomburgk \& Bentley 1841: 42. 
to British Guiana. He fulfilled this mission with success, incidentally discovering the giant Victoria regia (Fig 58) described and named by Lindley in honor of the British monarch.

Many orchids were collected by Schomburgk, among them the type specimen of the new genus Schomburgkia and over half a dozen species which bear the epithet schomburgkii or schomburgkianum.

Schomburgk returned to Guiana in 1841 , now as British official to survey the colony and to establish the boundaries between British Guiana, Suriname, Brazil and Venezuela. He devoted the next three and a half years to this mission, in the company of his brother Moritz Richard. In 1842, the two brothers went as far as the famous Roraima table-mountains, on the border between the British colony, Brazil and Venezuela. An interesting work with texts and illustrations was published by Schomburgk in 1841, including beautiful prints by the artist Charles Bentley based on sketches made during Schomburgk's expedition to the table mountains of Roraima (Fig 59). On his return to London in 1844, Schomburgk presented a detailed report of his journey to the Geographical Society and was knighted by Queen Victoria in 1845 .

August Kappler (1815-1887) was a German naturalist and explorer born in Mannheim. In 1836, Kappler enrolled in the Dutch Army and was destined to Suriname where he served a six-year term until 1842. His journal of his time in the colony was published in 1854 in a book entitled Sechs Jahre in Surinam oder Bilder aus dem militärischen Leben dieser Kolonie und Skizzen zur Kenntnis seiner sozialen und naturwissenschaftlichen Verhältnisse, (Six years in Suriname or images from the military life of this colony and sketches to its social and scientific circumstances) (Fig 60).

Kappler established himself in Paramaribo and ammassed a large collection of insects and plants which he sold mainly to European collectors. By 1846 he had earned enough money to purchase a plot of land on the Marowijne River, which he called "Albina", after his fiancée Albina Josefine Liezenmeier. He spent in Albina the next 33 years of his life. With the time, Albina would become a small settlement with a handful of European farmers. Kappler returned to Germany in 1879. When he died in Stuttgart, at the age of 71 , his coffin was covered with the flag of the Netherlands.

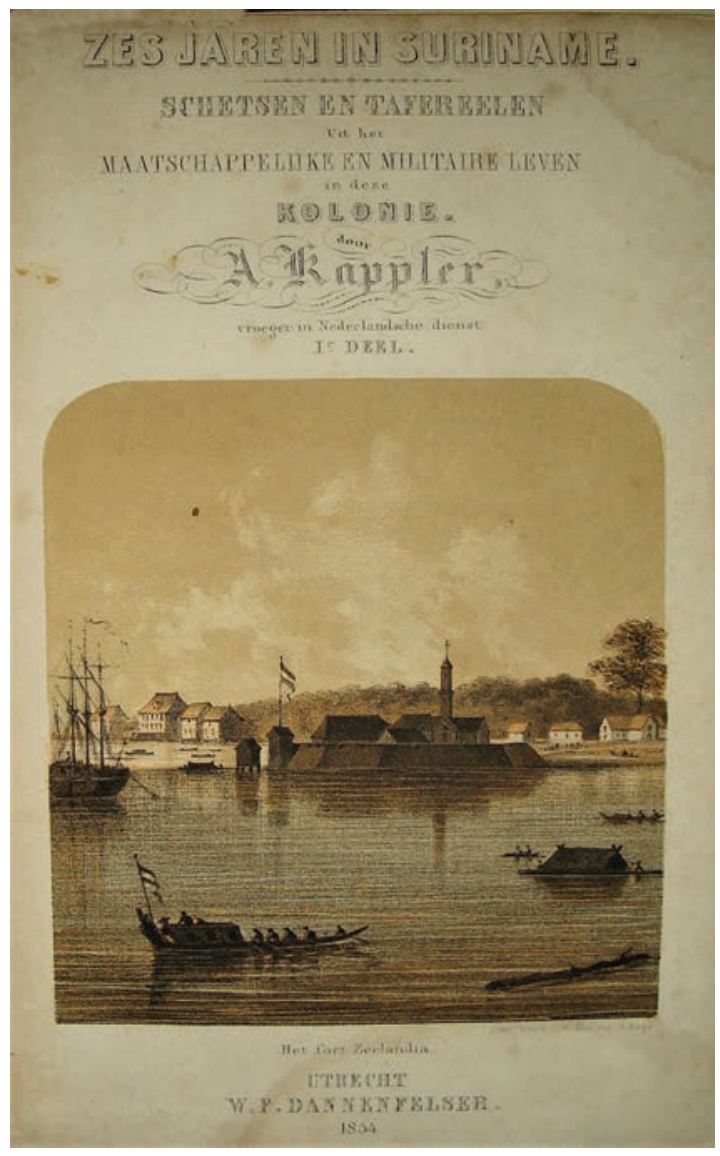

FIGURE 60. Frontispiece of Kappler's Sechs Jahre in Surinam oder Bilder aus dem militärischen Leben dieser Kolonie und Skizzen zur Kenntnis seiner sozialen und naturwissenschaftlichen Verhältnisse. Dutch edition, Utrecht 1854

August Kappler also made important botanical collections, often in the company of W.R. Hostmann. Among these, two new orchid species were named in his honor, Oncidium kappleri Rchb.f. ex Lindl. and Sturmia kappleri Rchb.f.

Hermann Aribert Heinrich Kegel (1819-1856) made botanical collections in Suriname between 1844 and 1846 under contract with the nurseries of Luis van Houtte in Gent, Belgium. A number of new orchids collected around Paramaribo were named after him by Reichenbach, among them Maxillaria kegelii, Cryptarrhena kegelii, Restrepia kegelii, and the genus Kegeliella. After returning to Germany he was offered the position of head gardener at the Botanical Garden of the University of Halle. 
The Moravian Evangelical Church of Herrenhut in Saxony, Germany (known as the "Bruedergemeinde," or "Community of the Brothers") began to send missionaries to the Caribbean in the early years of the eighteenth century, founding an establishment in Suriname in 1735. Heinrich Rudolf Wullschlaegel (1805-1864) came to the mission of the "Bruedergemeinde" in Suriname in 1849. An amateur botanist, he made some interesting collections, among them Notylia wullschlaegeliana H.Focke.

No important plant collections were made in the Guianas in the second half of the $19^{\text {th }}$ century, and it was only in the early 1900s that we see further botanical expeditions, again mostly to Suriname.

August Adriaan Pulle (1878-1955), a botany professor at the Dutch University of Utrecht, took part in the expedition to the region of Saramacca (Suriname) from 1902 to 1903 . His studies of the flora of the colony led him to publish, in 1906, An Enumeration of the Vascular Plants known from Surinam, together with their Distribution and Synonymy. In this work, he mentions a large number of Orchidaceae, although he complains that his knowledge of this plant family is very incomplete, mainly because many of the historical collections of orchids were locked at that time as part of the Reichenbach herbarium at the Natural History Museum in Vienna. He travelled again to Suriname in 1920, and in 1930 published the first part of his Flora of Suriname. Pulle was named Rector of the University of Utrech, a position he held from 1929 to 1930, and in 1938 presided over the South American Congress of Botany, which took place in Rio de Janeiro.

Although the harvest of orchids from the Guianas had been rich during the $19^{\text {th }}$ century, with Lindley and Reichenbach as its main beneficiaries, Rudolf Schlechter received only relatively few numbers of orchid specimens from this region. Only three plant collectors which worked in the three colonies can be named as part of Schlechter's network.

Sir Everard Ferdinand im Thurn (1852-1932; collected 1877-1897)

"Will no one explore Roraima and bring us back the tidings which it has been waiting these thousands of years to give us?" The Spectator, April 1877

"Nearly twenty-one years ago the Fates led me

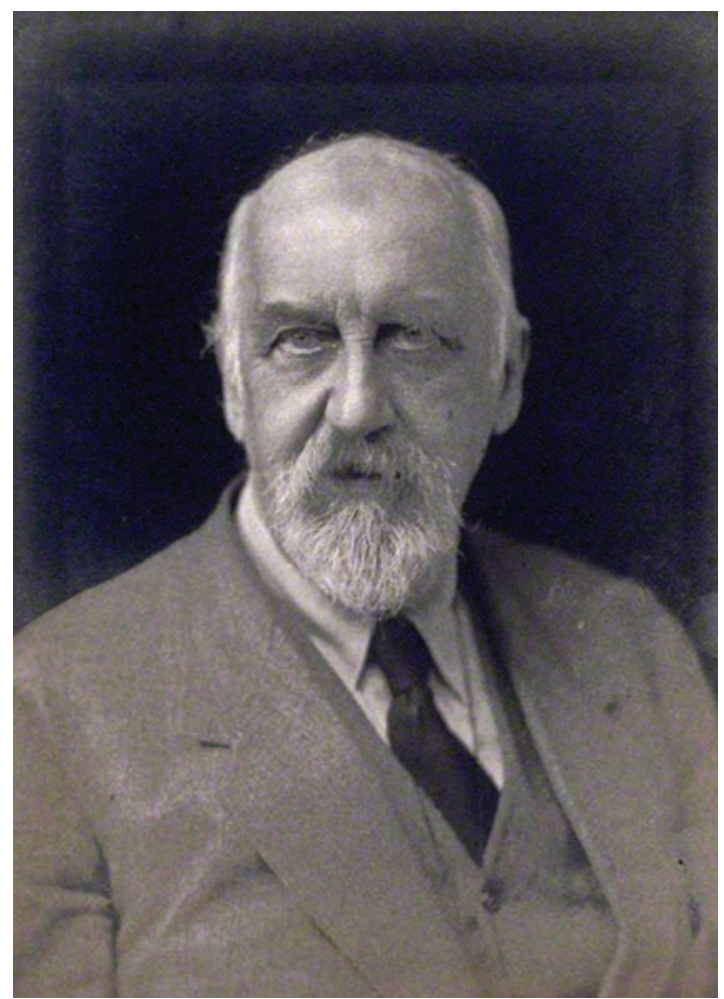

FIgURE 61. Everard Ferdinand im Thurn (1852-1932). Archives of Rudolf Jenny.

to Guiana and, nearly ever since, have detained me in the wilder and more remote parts of that region. Throughout, I have taken an interest in plants, and especially in the Orchids; and of late years whatever time I have been able to afford to botanical hobbies has been devoted almost exclusively to the ardous task of collecting, drying, dissecting and drawing orchids..." (Im Thurn 1888-1889: 40). With these words, Everard Ferdinand im Thurn (Fig. 61) described his first years in British Guiana and his predilection for the orchids of the colony. The above citation forms part of an article published by him in the journal of the Royal Horticultural Society, entitled Sketches of Wild Orchids in Guiana, in which Im Thurn gave a beautiful description of Guianas orchid world.

Im Thurn had begun studies at Exeter College in Oxford, but was forced to abandon after obtaining his undergraduate degree in 1875 when his father, a Swissborn businessman, went bankrupt. Recommended by Sir Joseph Hooker, a friend of his family considered at that time the "un-crowned King of British Guiana", 
Im Thurn was appointed curator of the museum in Georgetown, the colony's capital, a position in which he served from 1877 to 1882 (Aerni,1981). It was probably also Hooker, a lover of Orchidaceae, who pointed him in the direction of tropical orchids.

In 1882, im Thurn was appointed special magistrate of the Pomeroon River District where his work lay almost entirely among the Indian tribes of Guiana with whom he had close bonds of sympathy. He spent over 20 years in the colony, the last decade of the century as Government agent in the north-western districts.

Im Thurn's first description of Guyanese orchids was in his report on an ascend to Mount Russell, in the district of Pomeroon: “... an Epidendron was very common on the boulders; and another, this time a terrestrial orchid, either a Spiranthes or very closely allied to that genus, was not only more striking in appearance than most of this comparatively insignificant genus but surpassed every other orchid known to me, without exception, in the excellence of the scent." (im Thurn 1882: 226).

In 1883, a second expedition took him to the Orinoco River. He wrote in his report (im Thurn 1883): "Orchids, as might be expected from the damp character of the district, are unusually abundant; but these are not very different from those of other parts of Guiana. Probably because the district has been less visited and less despoiled than many others, several orchids, however, which were once abundant throughout the colony but are now rare elsewhere, are here abundant." (im Thurn 1883).

In 1884, im Thurn organized an expedition in the company of surveyor Harry L. Perkins to the famous table-mountains Roraima. They cut through dense forest which previous explorers had been unable to pass. "Surrounding the formidable barrier of Roraima's steep cliff face, the team circumnavigated a waterfall, and succeeded where none had before, ascending to the summit of the highest table-mountain, or tepui, in the region. The triumph was described in Nature as the "cherished object of botanical exploration in South America for the last quarter of a century", and held the public imagination for years to come" (JSTOR 2020).

Important botanical collections were made on the mountain (Fig. 62), a report of which was published by Im Thurn in 1887: The Botany of the Roraima Expedition of 1884, being notes on the plants observed (im Thurn 1887). A large number of orchids are mentioned in

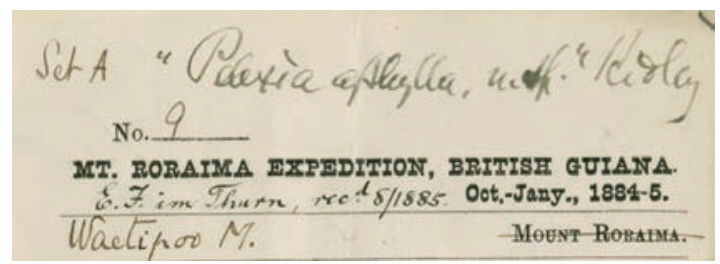

FIgURE 62. Im Thurn herbarium label from the Roraima expedition 1884 [Pelexia aphylla Ridl.].

this work, among them several new orchid species, collected by Im Thurn and described by Henry Ridley: Epidendrum alsum, Epidendrum imthurnii (Fig. 63AB), Epidendrum montigena, Epidendrum violascens (Fig. 63A), Pelexia aphylla (Fig. 64A-B), Spiranthes bifida, Stenoptera alata (Fig. 64A), and Zygopetalum venustum (Fig. 65).

The expedition was successful, however Im Thurn was not completely satisfied: "The number of species collected would probably have been greater but for the extreme difficulty of drying plants in so excessively damp a climate as that of Roraima, and also for the fact that the other very serious labours inseparable from the direction of such an expedition greatly curtailed the time I was able to devote to the preparation of botanical specimens. As regards the number of new generic and specific forms collected, great as it is, it would undoubtedly have been much greater but for the fact (unfortunate in this respect) that my collection was made at exactly the same period of the year [November and December] at which such collecting as had been done before about Roraima had been accomplished by Sir Robert and Dr. Schomburgk and by Karl Appun." (Im Thurn, 1887: 24).

Many orchid collections followed, the herbarium specimens often accompanied by detailed pencil drawings. Orchids were by far his preferred plant family, to an extent that from a total of 275 plant specimens collected by Im Thurn in Guiana and the Western Pacific which form part of Kew's digital herbarium catalogue, almost one third correspond to Orchidaceae (Fig. 66).

Alfred Coignaux described another new orchid species collected by Im Thurn: Cheiradenia imthurnii collected in the district Pomeroon (Fig. 67). Cogniaux mentions that the plant can also be found in northern Brazil, which is the reason for the description being published in the Flora Brasiliensis. 
A

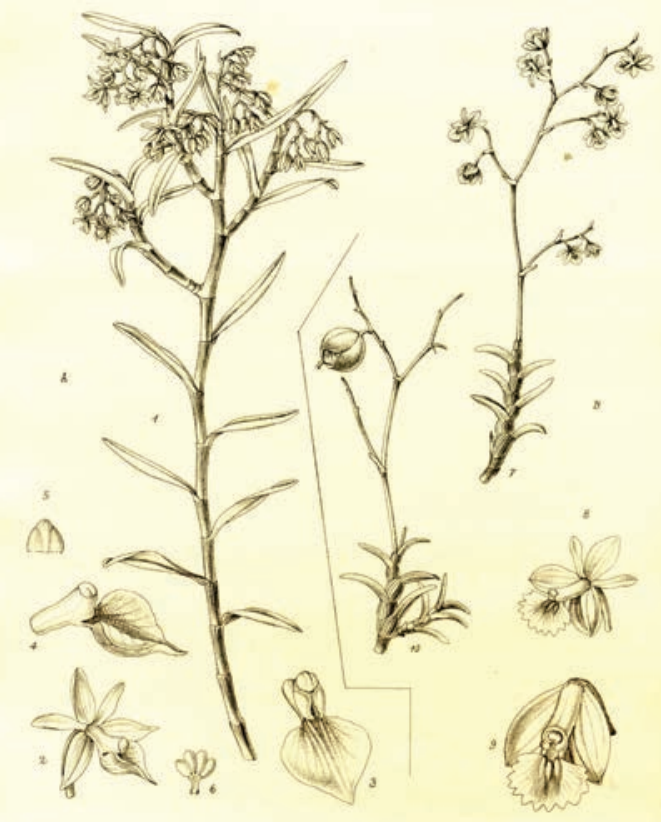

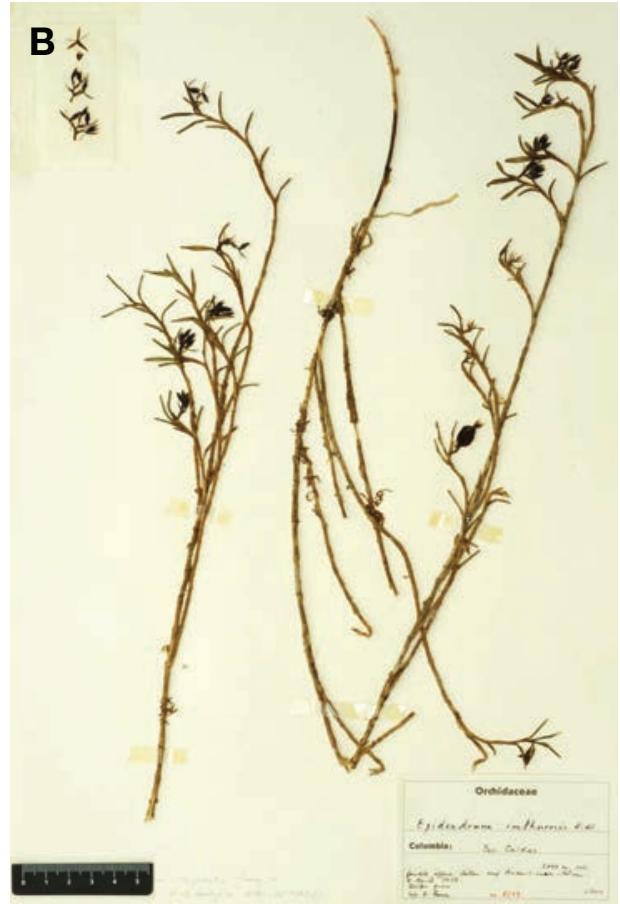

FiguRE 63. A. Epidendrum imthurnii Ridl. (left) and E. violacens Ridl. Illustration in The Botany of the Roraima Expedition of 1884, im Thurn 1887, plate 46. B. Epidendrum imthurnii Ridl. Herbarium specimen by J. Renz, \#1547. Collected in Caldas, Colombia.

A

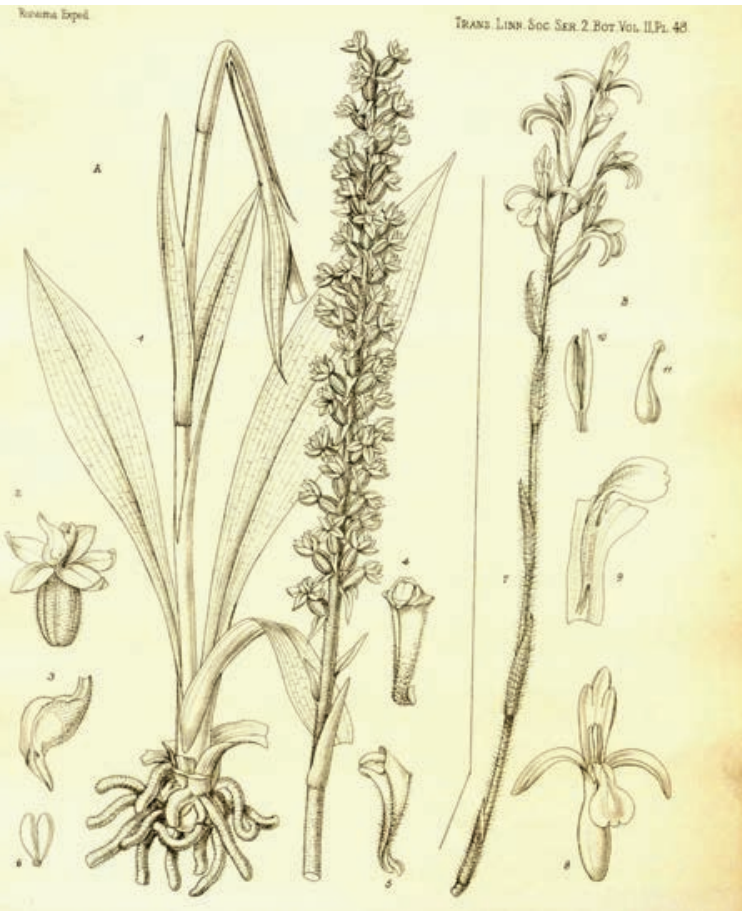

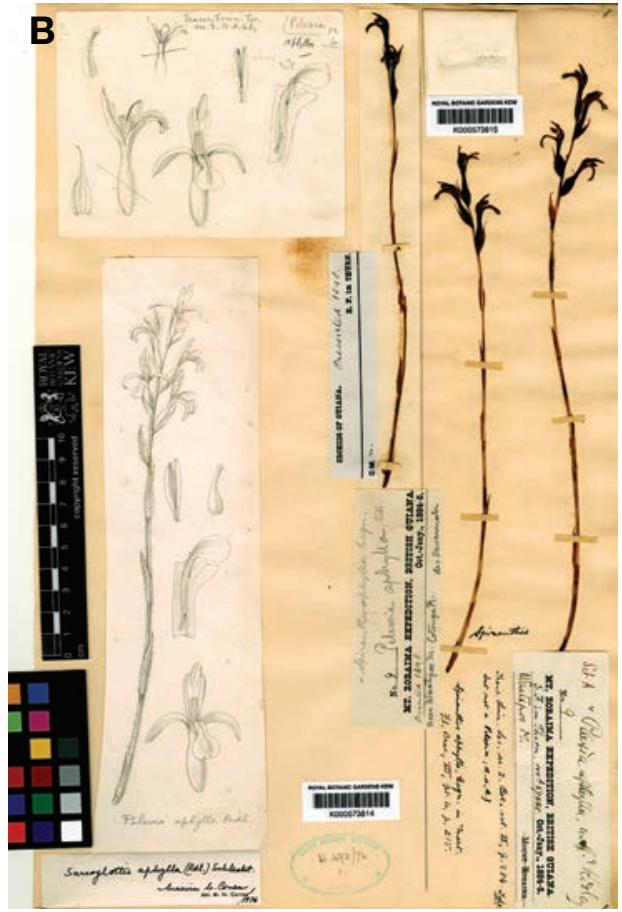

Figure 64. A. Stenoptera alata Ridl. (left) and Pelexia aphylla Ridl. Illustration in The Botany of the Roraima Expedition of 1884, im Thurn 1887, plate 47. B. Pelexia aphylla (K000573814/573815.), with pencil drawings by E.F. im Thurm. 
Rorama Exped

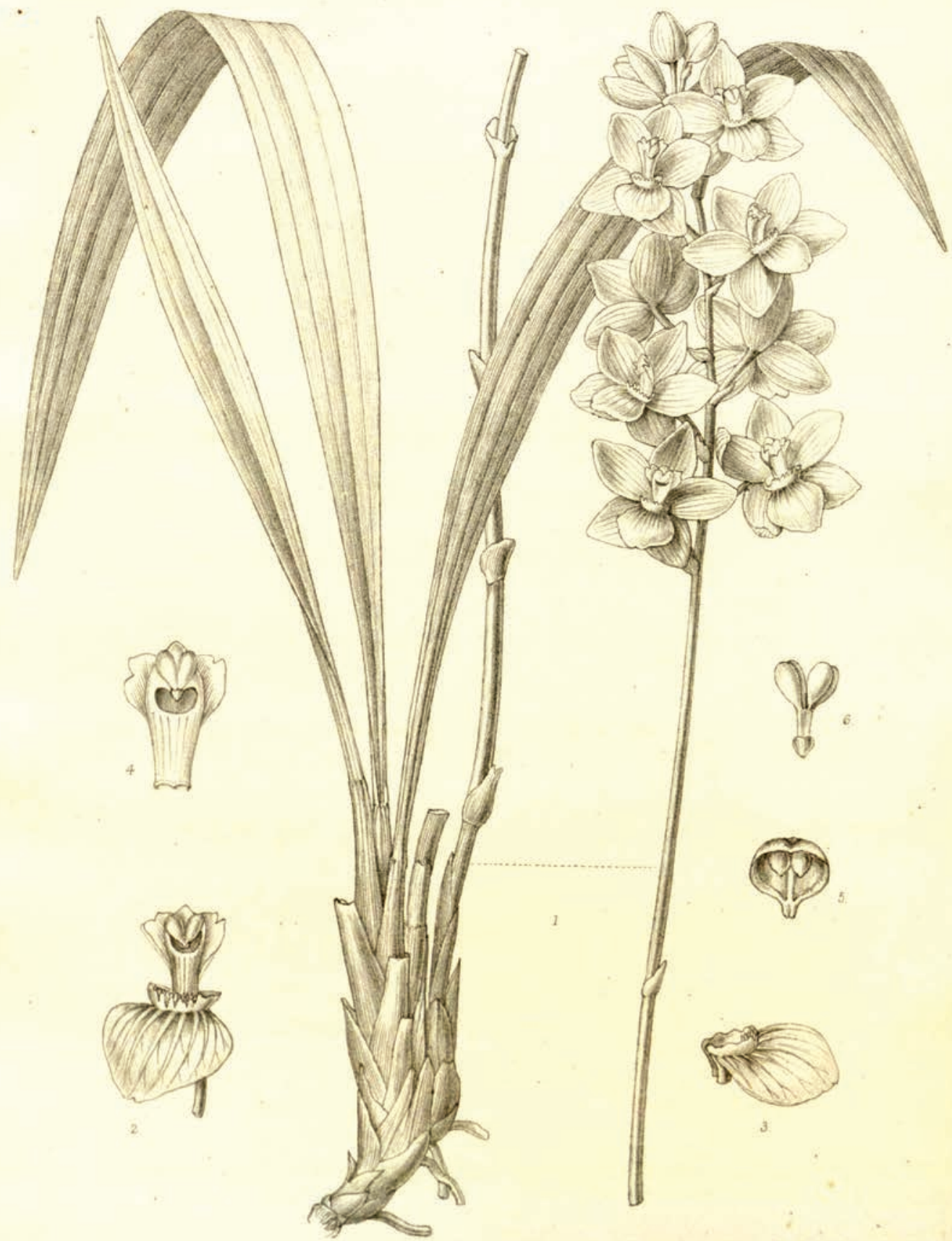

FIGURE 65. Zygopetalum venustum Ridl. Illustration in The Botany of the Roraima Expedition of 1884, im Thurn 1887 , plate 46. 


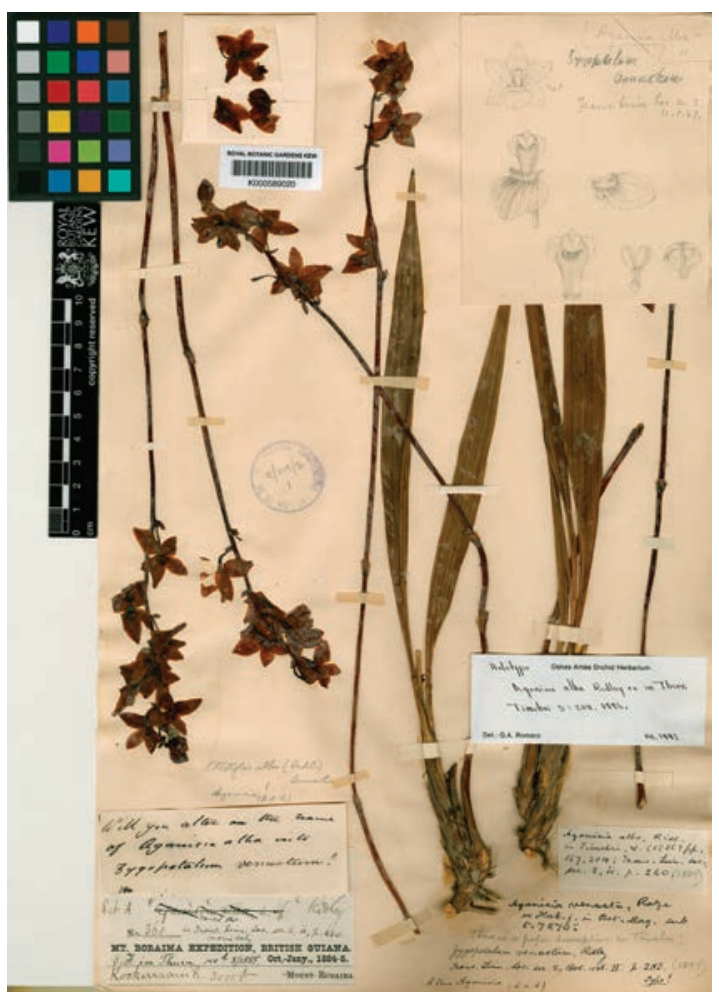

Figure 66. Aganisia alba Ridl. Holotype at Kew (K000589020), with a pencil drawings by E.F. im Thurm.

Charles Schweinfurth published in 1935 an article entitled "Additions to the Orchid Flora of British Guiana" in which - once more - he described new orchid species collected by E.F. im Thurn and sent by him to the herbarium in Kew: Stelis perparva (Fig. 68), Pleurothallis breviscapa, P. difussiflora, P. minima, $P$. pertenuis, Octomeria exigua, $O$. integrilabia, and $O$. parvula. A number of orchids from the Western Pacific region were also dedicated to Im Thurn: Calanthe imthurnii Kores, Dendrobium imthurnii Rolfe, and Microstylis imthurnii Rolfe.

"Anumbered series of 16 watercolours representing orchids native in British Guiana (now Guyana) in the collections of the Royal Botanic Gardens, Kew, have (with one exception) printed labels attached reading “ORCHIDS OF GUIANA. - E. F. im THURN." (Albuquerque 2012). It was originally believed that they were painted by E.F. im Thurn, but further research has showed that they came from the hand of his wife. Everard im Thurn returned to Great Britain in 1895, to marry Hannah Cassels Lorimer (1854-1947) in a ceremony at her

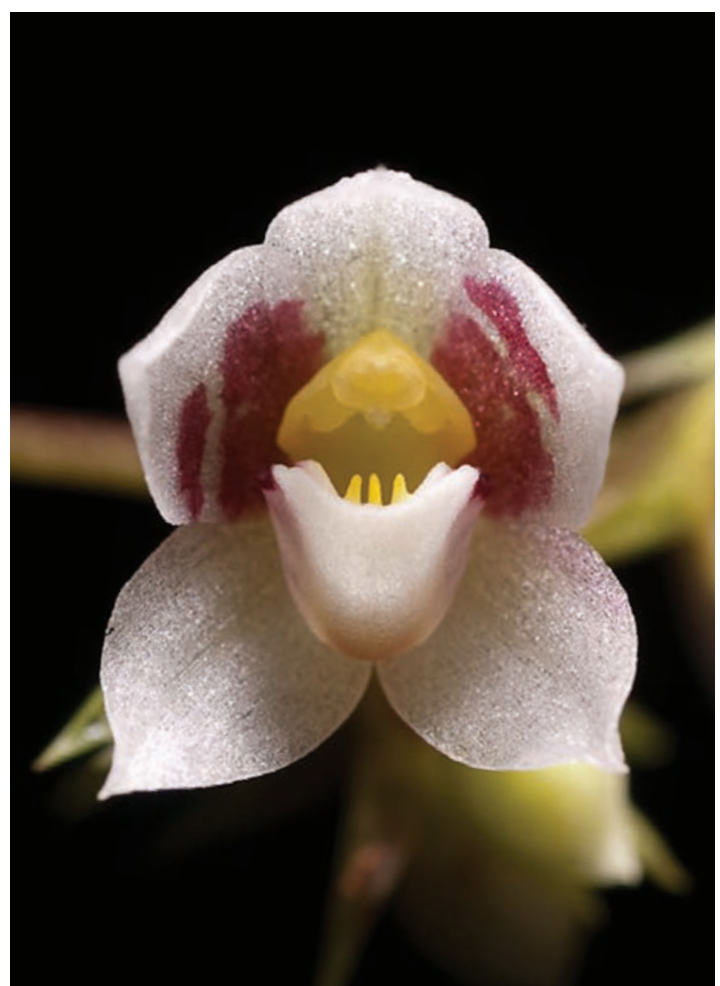

Figure 67. Cheiradenia imthurmii Cogn. (as C. cuspidata Lindl.) Phograph by T. Paine.

family home, Kellie Castle in Scotland. In a letter to Thiselton-Dyer dated 13 September 1896, im Thurn excused himself for not writing due to the time he had to devote in the previous year to "managing a wife".

Shortly afterwards the couple travelled to Guiana, where Hanna lived with her husband between 1895 and 1897, at the remote village of Morawhanna, near the border of Venezuela. There, the couple spent the evenings together, Im Thurn sorting, drawing and preparing his orchids specimens, while Hanna painted her series of beautiful watercolors based on her husband's sketches. Hannah's drawings are evidence of a fruitful exchange between husband and wife, resulting in at least sixteen illustrations of orchids which are now housed at Kew. Although not signed by Hannah, it is clear that these botanical illustrations should be attributed primarily to her. They reveal a keen eye for detail and a command of the media (watercolour and bodycolour) unlikely to have been achieved by someone with poor eyesight and without formal artistic training. Hannah's delight 


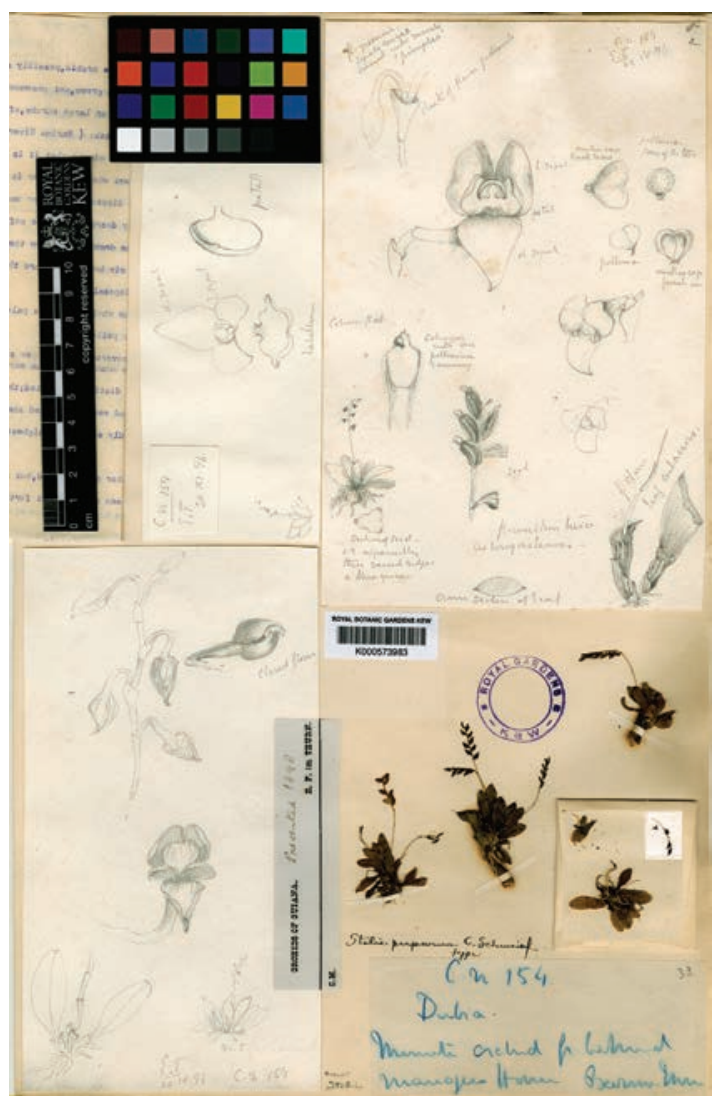

Figure 68. Stelis perparva C.Schweinf. Type at Kew, (K000573983), with a pencil drawings by E.F. im Thurm.

in documenting her observations is evident from her letters to her mother. As she noted in a letter from March 1897, "I have been painting the splendidest orchid I have ever seen, Coryanthes macrantha, very rare out here" (Albuquerque \& Martins 2018).

The list of orchids illustrated by Hanna is composed mainly of the showier species, with following genera represented: Aganisia, Bifrenaria, Catasetum, Cryptarrhena, Ionopsis, Leucohyle, Maxillaria, Notylia, Rodriguezia (Fig. 69), and Trigonidium .

However, there seem to have existed additional illustrations which have not been found yet. "Everard im Thurn showed 'some beautiful water-colour sketches of Guiana orchids' at the Royal Society's conversazione in Burlington House, Piccadilly, on Wednesday 3 May 1899. The reports do not state whether he was the artist. At least 20 genera were represented in the Royal Society exhibit." (Albuquerque 2012).

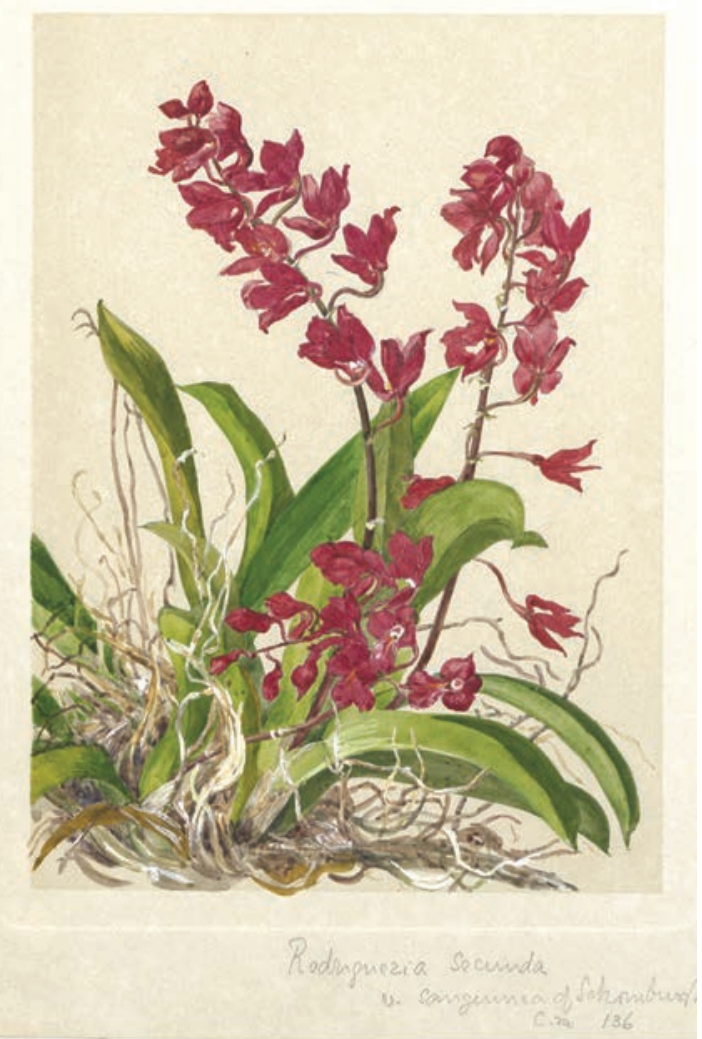

Figure 69. Rodriguezia secunda Kunth. Watercolor by Hanna Cassels im Thurn. Kew Botanic Gardens.

Charles Schweinfurth seems to confirm this in 1935, when describing a number of species of Pleurothallidinae collected in British Guiana by E.G. im Thurn, J. Jenman, and N.Y. Sandwith: "In general the descriptions are based on herbarium specimens, but in a few cases these were suplemented by water-color drawings. For the opportunity to describe this species, we are indebted to the Royal Botanic Gardens at Kew and to the New York Botanical Garden and extend our thanks to them for the loan of the material uppon which the descriptions were based." (Schweinfurth 1935). Taking into account that of the ten species described eight had been collected by E.F. im Thurn, we could easily asume that -again- we stand before some lost water-colors of Everard im Thurn and his wife Hanna.

Im Thurn returned to England in 1897 and in 1901 was appointed Lieutenant-Governor of Ceylon, in 1904 Governor of Fiji, High Commissioner of the Western 
Pacific and Consul-General for the Western Pacific Islands, until his retirement in 1910 (W.L.S. 1932). "It is chiefly as a scientific explorer and a Colonial Governor that his memory will be revered. British Guiana, Ceylon, Fiji and the Isles of the Western Pacific were eminently suitable fields for a man of his tastes and abilities and we are much the richer for the valuable work he did in these three Colonies" (Anonymous 1932).

Im Thurn was president of the Royal Anthropological Institute from 1919 to 1920 and the first president of the Edinburgh and Lothians Branch of the Royal Anthropological Institute from 1924 until 1932.

On his return from the summit of Roraima, Im Thurn authored several works related to his travels. Unexpected by him, this narratives inspired Sir Arthur Conan Doyle to write his novel of imperial adventure, The Lost World (1912), based on an expedition to a plateau in Venezuela where prehistoric animals had survived. The singular Maple White's Land described in this work of fiction has a great similarity with the "tepuy" Roraima (Dalziell 2002). Dalziell concludes: "Conan Doyles novel has become the shaping metaphor for later scientific and travel writing in British Guiana for the rest of the colonial period. The Lost World has come to symbolize European anxieties about vanishing species, cultural continuity and the role of science."

Over 300 specimens of orchids collected by E. F. im Thurn are distributed among the world's most important herbaria. Altogether it is a good representation of the orchid flora of British Guiana as known at his time. Among these we find samples of the following orchid genera: Aganisia, Cheiradenia, Epidendrum, Gomphichis, Habenaria, Macradenia, Maxillaria, Nohawilliamsia, Octomeria, Otostylis, Panmorphia, Platystele, Pleurothallis, Scaphyglottis, Sobralia, Specklinia, Stelis, Stenoptera, Vanilla, Veyretia, and Zygostates.

Rudolf Schlechter apparently did never meet Im Thurm in person. However, the latter's botanical collections, and those of other botanists who had worked in Guiana in the past were of great importance to him. As he wrote in 1919: "The collections made on the Roraima by Schomburgk, Burke, im Thurn, Quelch, Connell and Ule have shown how many interesting and characteristic species can be found here. These collections are all what we know from this undoubtedy very rich region." (Schlechter 1919).

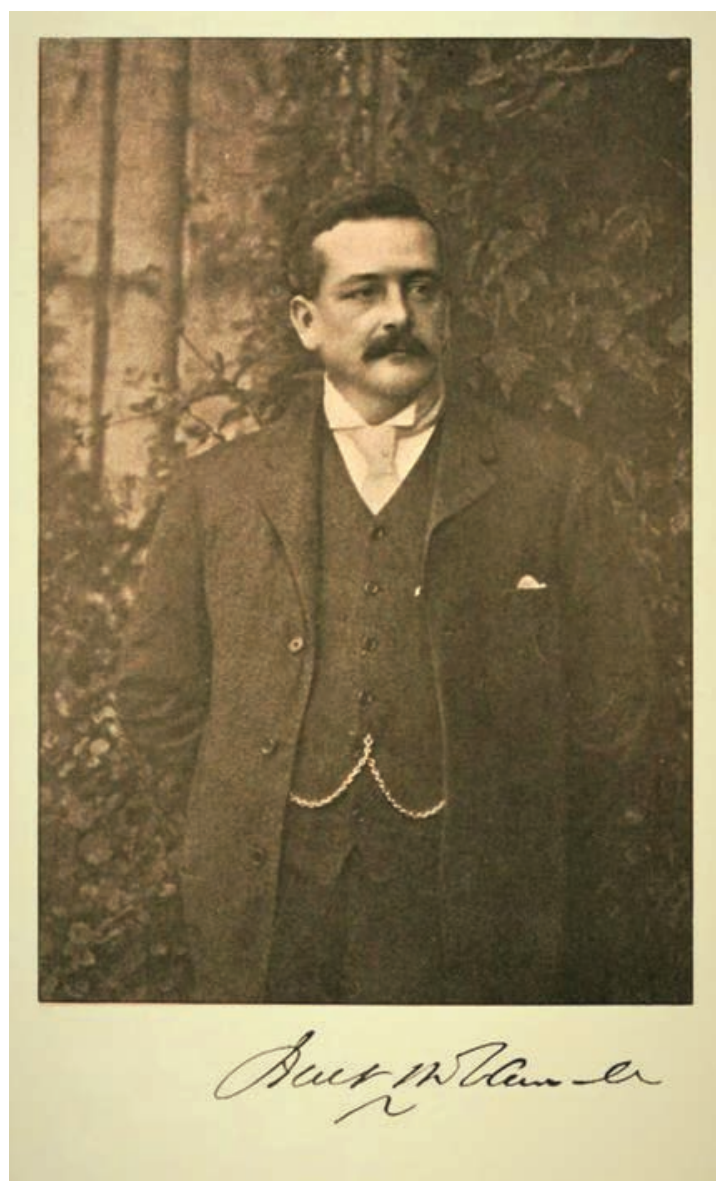

FiguRE 70. Frederick Vasavour MacConnell. In Charles Chubb, The birds of British Guiana (1916).

Frederick Vavasour McConnell (?-1914) and John Joseph Quelch (1854-?; collected 1894-1898)

John McConnell, trader and plantation owner in British Guiana, passed away in 1890. His three companies, Booker Brothers \& Co., George Booker \& Co., and John McConnell \& Co., passed to his sons Arthur John and Frederick Vavasour McConnell (Fig. 70) (Hollett 1999). Frederick established himself in Georgetown (Fig. 71), and besides his business interests, passed much of his time studying the natural history of the colony. Based on his ornithological collections, Charles Chubb would publish in 1916 his The birds of British Guiana, in which a new species of piculet was illustrated, Picumnus macconnelli, which had been described by Sharpe in 1901. Another species, McConnell's flycatcher (Mionectes macconnelli) was described by Chubb a few years later. 


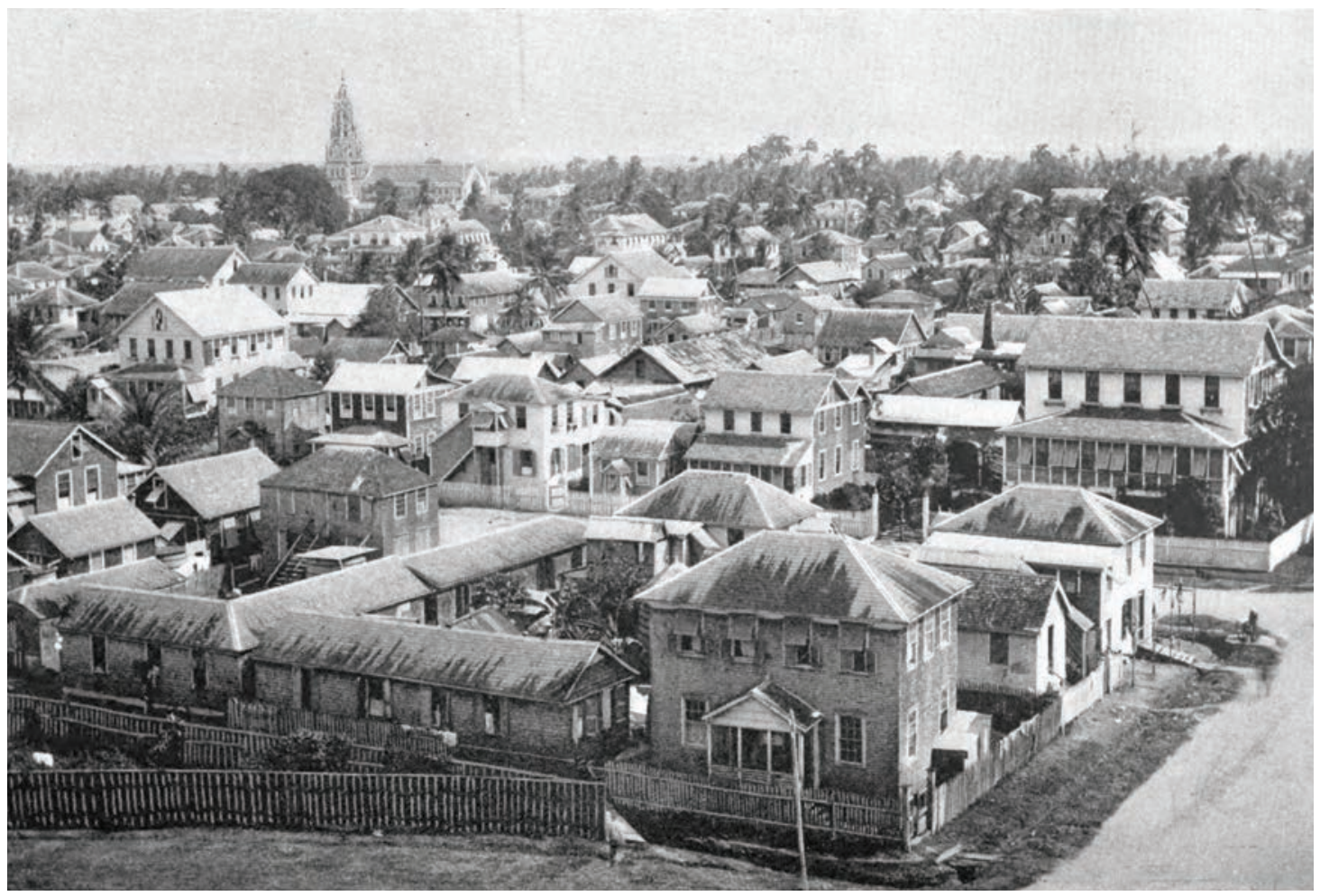

FIGURE 71. Georgetown, ca. 1890. James Roadway, Handbook of British Guiana (1893).

John Quelch (1854-?) (Fig. 72) held a position as zoologist at the British Museum until 1886, when he was appointed curator at the Museum of British Guiana. In the same year he contributed to the report of HMS Challenger, the scientific expedition commissioned by the British Government in 1872-1876 that sailed over 80,000 miles around the world, with his Report on the Reef-Corals Collected by H.M.S. Challenger During the Years 1873-76. Quelch was editor of the Guianan journal Timehri from 1887 to 1893 and wrote on topics as diverse as fish and coral, botany and entomology.

J.J. Quelch made the acquaintance of Frederick Mc Donnell while working at the museum in Georgetown, and together they made frequent excursions to the surroundings of the capital city and different other points of the colony. Although their interests were mainly zoological, they made important botanical discoveries during the last decade of the 19th century.

McConnell's and Quelch's main contribution to the knowledge of British Guiana's natural history were their two expeditions (1894 and 1898) to Mount Roraima, on the border between Guiana, Venezuela

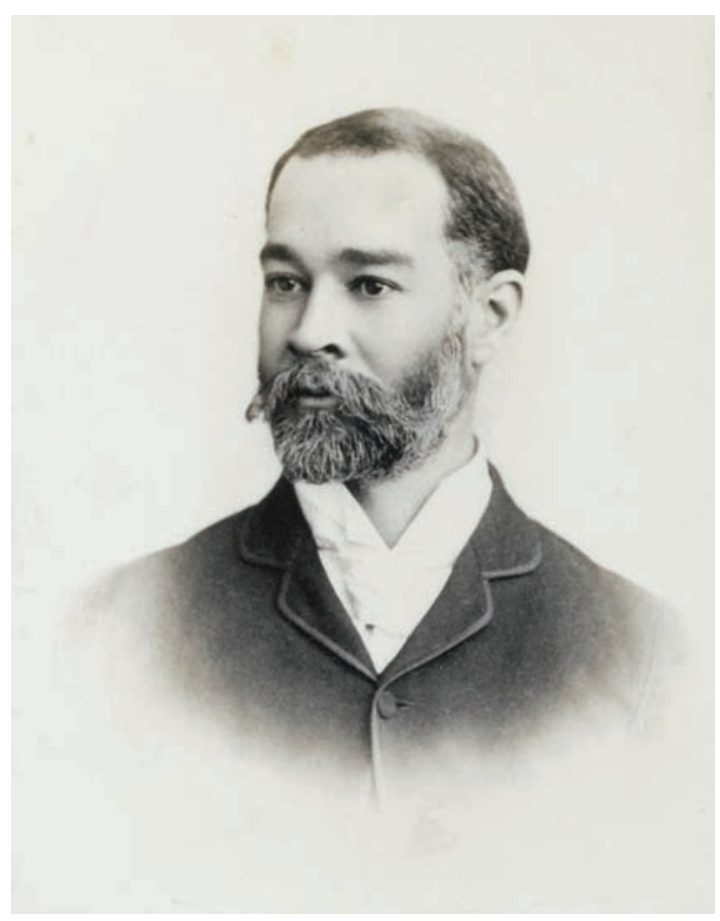

FIGURE 72. John Joseph Quelch. Unknown photographer. 


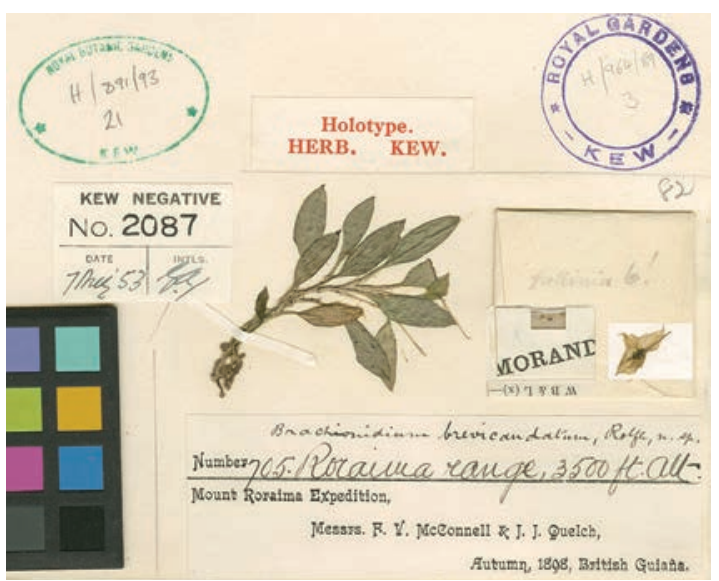

FiguRE 73. Brachionidium brevicaudatum Rolfe. Holotype at the Royal Botanic Gardens, Kew (K0000583670).

and Brazil, during which they followed in the footsteps of their mutual friend E. F. im Thurn. Both times they reached the plateau on the summit of the mountain. The botanical results of both expeditions were published by N. E. Brown in 1901. In this work, the treatment on Orchidaceae was by Robert A. Rolfe (Brown 1901). Rolfe described from McConnell and Quelch's collections an important number of new orchid species: Brachionidium brevicaudatum (Fig. 73), Bulbophyllum roraimense, Houlettia roraimensis, Maxillaria connellii, M. quelchii (Fig. 74), Octomeria connellii, O. parvifolia, Pleurothallis roraimensis, Stelis guianensis, and Habenaria roraimensis.

Albert William Bartlett (1875-1943; collected 1903-1929)

Biographical information about Albert William Bartlett (1875-1943) is scarce. He received a Bachelor's degree in Botany in London in 1898 and was elected member of the Linnean Society in 1903. In this year he was named Superintendent of the Botanic Garden and Government Botanist in Georgetown, British Guiana, a position he held until 1908.

After he returned to England he worked as Assistant lecturer in Botany at the University of Sheffield (19091920 ) and Lecturer in Botany at Armstrong College in Newcastle-on-Tyne from 1920 to 1939.

Only one new orchid species is known among the collections of A.W. Bartlett, Neobartlettia guianensis

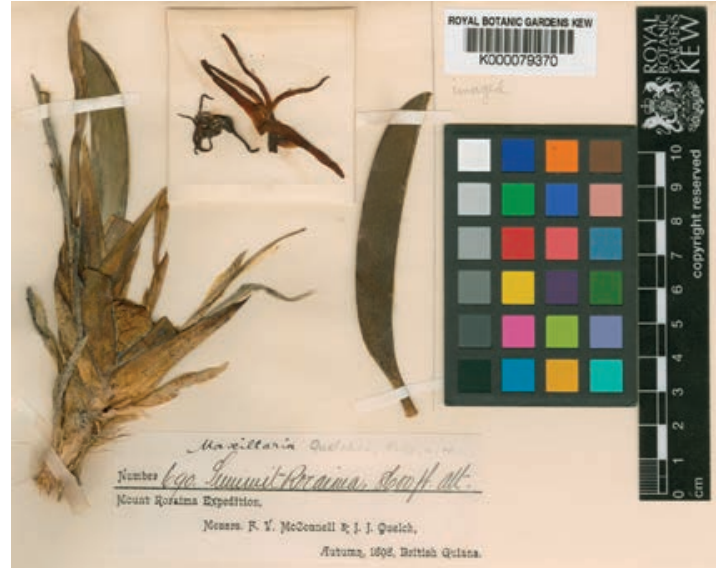

FiguRE 74. Maxillaria quelchii Rolfe. Specimen at the Royal Botanic Gardens, Kew (K000079370).

Schltr. (Fig. 75A), which served as the type species for the new genus Neobartlettia. In the same publication Schlechter made a new combination, transferring Palmorchis sobralioides Barb. Rodr. (Fig. 75B) to the new genus. As Schlechter wrote: "The new genus is dedicated to the discoverer of one of the species, A.W. Bartlett, Superintendent of the Botanical Garden in Georgetown, who has dedicated himself to the exploration of the flora of British Guiana" (Schlechter 1920).

Thus we come to the end of this enumeration of botanists and collectors, who -in one way or the otherwere essential for Rudolf Schlechter in his work on the orchids of South America. The geographical scope of the work has so far been limited to the non-Spanishspeaking countries: Brazil and the three Guianas.

The following chapters will deal with the former Spanish colonies: Venezuela, Ecuador, Colombia, Peru, Bolivia, Chile, Argentina, Uruguay, and Paraguay.

Acknowledgements. To the Royal Horticultural Society Lindley Collections for supplying the digital images of the orchid paintings by J.H. Lance and G. Schouten. To Crestina Forcina, Digital Images Assistant and Charlotte Brooks, Art Curator, both of the RHS Lindley Library, for all their kind help in this matter. All images of these paintings are reproduced by permission of the RHS Lindley Collections. Finally, to Franco Pupulin for the determination of the species painted by Lance and Schouten. Mark Budworth, as always, took painful care of the philological revision of the text. 

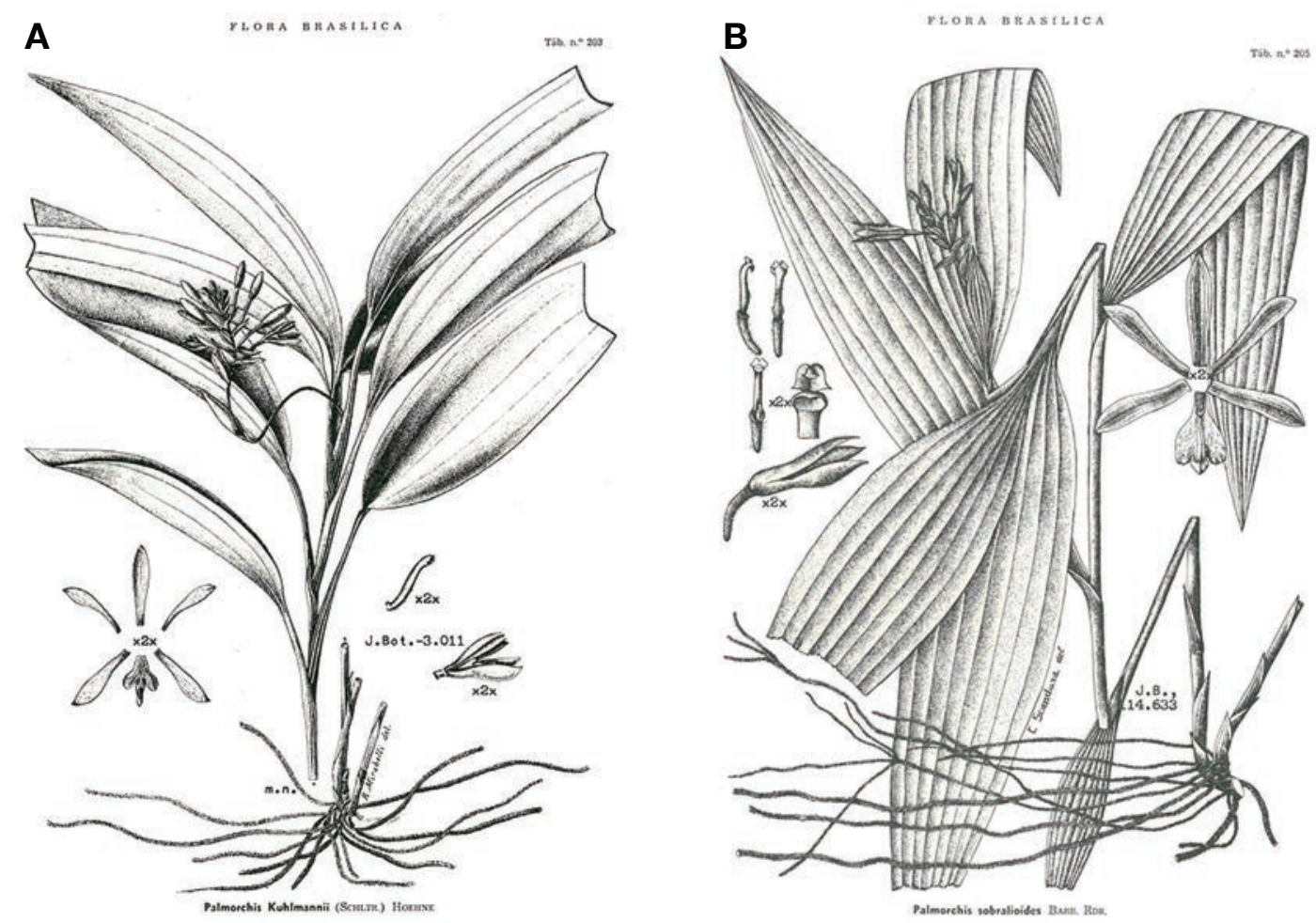

Figure 75. A. Neobartlettia guianensis Schltr. [as Palmorchis kuhlmannii (Schltr.) Hoehne]. B. Neobartlettia sobralioides (Barb.Rodr.) Schltr. [as Palmorchis sobralioides Barb.Rodr.]. Plates 203 and 205from F.C. Hoehne, Flora Brasilica, 1945 .

\section{LITERATURE CITED}

Aerni, A. T. (1981). Sir Everard im Thurn. Schaffhauser Beiträge zur Geschichte, Biographien, 58, 348-357.

Aerni, A. T. (1992). Jacques (Jakob) Huber. Schaffhauser Beiträge zur Geschichte, Biographien, 68, 87-93.

Albuquerque, S. (2012). Watercolours of orchids native to British Guiana at the Royal Botanic Gardens, Kew, attributed to Hannah Cassels im Thurn (1854-1947). Archives of Natural History, 39(2), 344-347.

Albuquerque, S. \& Martins, L. (2018). Place, gender and the making of natural history: Hannah im Thurn in British Guiana, 1895-1897. Journal of Historical Geography, 62, 1-14.

Anonymous. (1932). In Memoriam - Sir Everard im Thurn, K.C.M.G., K.B.E., C.B. The Malburian, 67, $206-207$.

Anonymous. (1953). Crónica - Robert Pilger. Revista Argentina de Agronomía, 20, 107-114.

Arellano, H., Bernal-Gutiérrez, G., Calero-Cayopare, A., Castro-L., F., Lozano, A., Bernal-Linares, D. S., Méndez-R., C. \& Aymard C., G. (2019). The first botanical exploration to the Upper Cuiarí (Cuyarí) and Isana Rivers, Upper Río Negro

Basin, Guainía Department, Colombia. Harvard Papers in Botany, 24(2), 83-102.

Archer, W. A. (1962). Adolpho Ducke, Botanist of the Brazilian Amazon (1876-1959). Taxon, 11(8), $233-235$.

Aublet, J. B. C. F. (1775). Histoire des plantes de la Guiane Françoise. Paris: P. F. Didot jeune.

Barbosa Rorigues, J. (1877). Genera et Species Orchidearum Novarum. Rio de Janeiro: C. \& H. Fleiuss.

Barrère, P. (1741). Essai sur Histoire Naturelle de la France Equinoxiale. Paris: Piget.

Barrère, P. (1743). Nouvelle Relation de la France Equinoxiale. Paris: Piget.

Bates, H. W. (1863). The Naturalist on the River Amazon. London: Murray.

Batista, J. N., Bem Bianchetti, L. de, González Tamayo, R., Figueroa, X. M. C. \& Cribb, P. (2011). A Synopsis of New World Habenaria (Orchidaceae). II. Harvard Papers in Botany, 16(2), 233-273.

Brogiato, H. P. (2019). Meyer, Herrmann August Heinrich. In: Sächsische Biografie, Institut für Sächsische Geschichte und Volkskunde e.V. Retrieved from www.isgv.de/saebi [Accessed March, 2020]. 
Brown, N. E. (1901). Report on two botanical collections made by Messrs. F. V. McConnell and J. J. Quelch on Mount Roraima in British Guiana (Orchidaceae by R.A. Rolfe). Transactions of the Linnean Society of London, second series, $6,1-65$.

Chubb, C. (1916). The birds of British Guiana: based on the collection of Frederick Vavasour McConnell. London: Bernard Quaritch.

Dalziell, R. (2002). The Curious Case of Sir Everard im Thurn and Sir Arthur Conan Doyle: Exploration \& the Imperial Adventure Novel, The Lost World. English Literature in Transition, 1880-1920, 45(2), 131-157.

de La Condamine, C. M. (1745). Relation Abrégée d'un Voyage fait dans l'Intériéur de l'Amérique Méridionale, Depuis la Côtes de la Mer du Sud, jusqu'aux Côtes du Brésil \& de la Guyane, en Descendant la Riviere des Amazones. Paris: Veuve Pissot.

DeFilipps, R. A. (1992). Ornamental Garden Plants of the Guianas. An Historical Perspective of Selected Garden Plants from Guyana, Suriname and French Guiana. Washington, D.C.: Smithsonian Institution.

dos Santos, Karin. (2016). Brazilian plant specimens at the Regnellian herbarium: history and repatriation. Rodriguésia, 67(4), 879-892.

Ducke, A. (1945). Um pseudo-botânico Nazi no Brazil. Ph. von Luetzelburg e sua conferencia sobre a fitogeografia de Amazonia. Revista Veterinaria, Belem, 8(33), 17-19.

Ducke, W. A. \& Huber, J. (1909). Plantae Duckeanae austro-guyanenses. Boletim do Museu Goeldi, 5(2), $294-436$.

Eckhardt, T. (1966). 150 Jahre Botanisches Museum Berlin (1815-1965). Willdenowia, 4(2), 151-182.

Egler, W. (1963). Adolpho Ducke - Traços biográficos, viagens e trabalhos. Boletim do Museo Paraense Emilio Goeldi. Botânica, 18, 1-130.

Florez, L. S., Sanjad, N. \& Okadu, W. (2018). Construção do espaço museal: ciência, educação e sociabilidade na gênese do Parque Zoobotânico do Museu Goeldi (1895-1914). Anais do Museu Paulista, Nova Série, 26, 1-67.

Focke, H. C. (1850). Enumeratio diagnostica Orchidearum quarund Surinamensium. Tijdschrift voor de wi-sen natuurkundige wetenschappen, 4, 62-72.

Harms, H. (1916). Biography of Ernst Ule (1854-1915). Verhandlungen des botanischen Vereins der Provinz Brandenburg, $57,150-184$.

Hoehne (1940-1968). Flora Brasilica. São Paulo: Romiti \& Lanzara.

Hollett, D. (1999). Passage from India to El Dorado - Guyana and the Great Migration. Massachusetts: Associated University Presses.

im Thurn, E. F. (1882). A journey to Mount Russell in Guiana. Timehri, being the journal of the Royal Agricultural and Commercial Society of British Guiana, 1, 216-228.

im Thurn, E. F. (1883). A journey to Mount Russell in Guiana. Timehri, being the journal of the Royal Agricultural and Commercial Society of British Guiana, 3, 211-239.

im Thurn, E. F. (1887). The Botany of the Roraima Expedition of 1884, being notes on the plants observed. Transactions of the Linnean Society, 2(13), 249-300.

im Thurn, E. F. (1888-1889). Sketches of Wild Orchids in Guiana. Journal of the Royal Horticultural Society, 22 , 40-52.

JSTOR. (2020). Thurn, Everard Ferdinand im (1852-1932). Retrieved from https://plants.jstor.org/stable/10.5555/al.ap. person.bm000008465 [Accessed March, 2020].

Kappler (1854). Sechs Jahre in Surinam - Bilder aus dem militärischen Leben dieser Colonie und Skizzen zur Kenntniss seiner sozialen und naturwissenschaftlichen Verhältnisen. Stuttgart: Schweizerbartsche Verlagsbuchhandlung und Druckerei.

Koch-Grünberg, T. (1906). Bericht über seine Reisen am oberen Rio Negro und Yapura in den Jahren 1903-1905. Zeitschrift der Gesellschaft für Erdkunde zu Berlin, 80-101.

Koch-Grünberg. T. (1910). Zwei Jahre unter den Indianern (2. Vols.). Berlin: Ernst Wassmuth A.G.

Koch-Grünberg, T. (1917). Vom Roroima [sic] zum Orinoco. Berlin: Dietrich Reimer (Ernst Vohsen).

Koch-Grünberg, T. (1921). Zwei Jahre bei den Indianern Nordwest-Brasiliens. Stuttgart: Strecker und Schroeder Verlag.

Koch-Grünberg, T. (1994). Informe sobre mis viajes al alto río Negro y al Caquetá en los años 1903-1905. Boletín Museo del Oro, Bogotá, 36, 112-134.

Koch-Grünberg, T. (2004). Die Xingú-Expedition (1898-1900). Edited by M. Kraus. Köln: Böhlau Verlag.

Kraus, M. (2015). Of plants and men. A botanist documents the Amazon. In G. Wolff (ed.), Explorers and Entrepreneurs behind the camera (pp. 106-115). Berlin: Ibero-Amerikanisches Institut Preußischer Kulturbesitz.

Kraus, M. (2018). Testigos de la época del caucho: experiencias de Theodor Koch-Grünberg y Hermann Schmidt en el alto río Negro. Germany: Georg-August-Universität Göttingen. 
La Serna, J. C. (2018). Forest, Photography and Exposition. Visual construction of the Amazonian forest through the clichés of Charles Kroehle and the Republica Peruana 1900 album. Histoire(s) de l'Amérique latine, 13, 1-21.

Mansfeld, R. (1928). Orchidaceae Amazonicae Huebnerianae. Notizblatt des Botanischen Gartens und Museums zu BerlinDahlem, 10, 378-382.

Mansfeld, R. (1934). IV. Orchideologische Mitteilungen II. Repertorium Specierum Novarum Regni Vegetabilis, $36,58-64$.

Melchior, H. (1955). Robert Pilger (1876-1953). Berichte der Deutschen Botanischen Gesellschaft, 68a, $293-297$.

Melchior, H. (1955a). Zum Gedächtnis von Robert Pilger. Botanische Jahrbücher für Systematik, Pflanzengeschichte und Pflanzengeographie, 76, 384-409.

Meyer, G. F. W. (1818). Primitiae Florae Essequeboensis adjectis descriptionibus centum circiter stirpium novarum observationibusque criticis. Gottingae: Sumptibus H. Dieterich.

Meyer, E. H. F. (1825). Plantarum Surinamensium: corollarium primum. Nova acta physico-medica academiae Caesareae leopoldino-Carolinae naturae curiosorum.

Mutis, J. C. (1954-2010). Flora de la Real Expedición Botánica del Nuevo Reino de Granada. Vols. 7-11: Orchidaceae I, II, III, IV, $V$. Madrid: Ediciones Cultura Hispánica.

Ossenbach, C. (2020a). A History of Orchids in South America. Volume I-Colonial times: from discovery to independence. Oberreiffenberg, Germany: Koeltz Botanical Books.

Ossenbach, C. (2020b). The orchids of John Henry Lance (1793-1878). Lankesteriana, 20(1), 57-78.

Ossenbach, C. \& Jenny, R. (2019). Rudolf Schlechter's South American Orchids II. Schlechter's "Network": Brazil (La Plata River Basin). Lankesteriana, 19(3), 201-252.

Pilger, R. (1901). Beitrag zur Flora von Mattogrosso [Orchidaceae by R. Schlechter]. Botanische Jahrbücher für Systematik, Pflanzengeschichte und Pflanzengeographie, 30, 127-238.

Pilger, R. (1910). Verzeichnis der auf der Expedition gesammelten Pflanzen. In T. Koch-Grünberg (Ed.), Zwei Jahre unter den Indianern (edition 2010), vol. 2 (360-373). Cambridge: Cambridge University Press.

Pilger, R. (1914). Plantae uleanae nova vel minus cognitae [Orchidaceae by R. Schlechter]. Notizblatt des Königlichen Botanischen Gartens und Museums zu Berlin-Dahlem, 6(54), 109, 360-373142.

Pilger, R. (1921a). Plantae Lützelburgianae brasilienses. Part I. Notizblatt des Königl. botanischen Gartens und Museums zu Berlin, 8, 425-451.

Pilger, R. (1921b). Plantae Lützelburgianae brasilienses. Part II. Notizblatt des Königl. botanischen Gartens und Museums zu Berlin, 8, 535-536.

Pilger, R. (1921c). Plantae Lützelburgianae brasilienses. Part III. Notizblatt des Königl. botanischen Gartens und Museums zu Berlin, 8, 711-716.

Pilger, R. (1924a). Plantae Lützelburgianae brasilienses. Part IV. Notizblatt des Königl. botanischen Gartens und Museums zu Berlin, 9, 39-48.

Pilger, R. (1924b). Plantae Lützelburgianae brasilienses. Part V. Notizblatt des Königl. botanischen Gartens und Museums zu Berlin, 9, 153-156.

Pilger, R. (1925). Plantae Lützelburgianae brasilienses. Part VI. Notizblatt des Königl. botanischen Gartens und Museums zu Berlin, 9, 377-407.

Pilger, R. (1927). Plantae Lützelburgianae brasilienses. Part VII. Notizblatt des Königl. botanischen Gartens und Museums zu Berlin, 10, 43-54.

Pulle, A. A. (1906). An enumeration of the vascular plants known from Surinam: together with their distribution and synonymy. Leiden: E. J. Brill Ltd.

Pulle, A. A. (1930). Flora of Suriname. Reprint 1968 by J. Lanjouw. Leiden: E. J. Brill Ltd.

Quelch, J. J. (1886). Report on the Reef-corals Collected by H. M. S. Challenger During the Years 1873-76. H. M. Stationery Office. Andesite Press.

Rodway, J. (1893). Handbook of British Guiana. Georgetown: Royal Agricultural and Commercial Society of British Guiana.

Rolander, D. (1811). Diarum surinamense, quod sub itinere exotico conscripsit Daniel Rolander. Copenhagen: Private publication by Christen Friis Rottbøll.

Sanjad, N., Oren, D. C., de Sousa e Silva Junior, J., Hoogmoed, M. S. \& Higuchi, H. (2012). Documentos para a história do mas antigo jardim zoológivo do Brasil: o Parque Zoobôtanico do Museo Goldi. Boletim do Museo Paraense Emilio Goeldi. Ciências Humanas, 7(1), 197-258.

Schlechter, R. (1919). Die Orchideenfloren der südamerikanischen Kordillerenstaaten. I. Venezuela. Repertorium Specierum Novarum Regni Vegetabilis, Beihefte, 6, 1-100. 
Schlechter, R. (1920). Orchidaceae novae et criticae, Decas LXVI, LXVII. Repertorium Specierum Novarum Regni Vegetabilis, 16, 440-442.

Schlechter, R. (1921). Orchidaceae novae et criticae, Decas LXX. Additamenta ad Orchideologiam Brasiliensem. Repertorium Specierum Novarum Regni Vegetabilis, 17, 267-272.

Schlechter, R. (1926). Beitraege zur Orchideenkunde des Amazonas-Gebietes, II. Orchidaceae Huebnerianae. Repertorium Specierum Novarum Regni Vegetabilis, 42, 67-150.

Schlechter, R. \& Hoehne, F. C. (1926). Contribuções ao Conhecimento das Orchidáceas do Brasil. Archivos de Botânica do São Paulo, 1, 203-216.

Schmassmann, W. (1939). Dr. Leo Zehnter, Reigoldswil: zum 75. Geburtstag und zur Ernennung als Ehrenmitglied unserer Gesellschaft. Tätigkeitsbericht der Naturforschenden Gesellschaft Baselland, 12, 26-35.

Schmassmann, W. (1961). Leo Zehntner, 1864-1961. Verhandlungen der Schweizerischen Naturforschenden Gesellschaft. Wissenschaftlicher und administrativer Teil, 141, 269-272.

Schoepf, D. (2005). George Huebner (1862-1935). Um fotógrafo em Manaus. Genéve, Switzerland: Metalivros Imprimierie Genevoise S.A.

Schomburgk, R. \& Bentley, C. (1841). Twelve views of the interior of Guiana. London: Ackermann and Co.

Schweinfurth, C. (1935). Additions to the Orchid Flora of British Guiana. Botanical Museum Leaflets, 3(6), 77-91.

Spruce, R. (2014). Notes of a botanist on the Amazon and Andes, being records of travels on the Amazon and its tributaries, the Trombetas, Rio Negro, Uaupés, Casiquiari, Pacimoni, Huallaga and Pastana. Edited by A.R. Wallace. Cambridge: Cambridge University Press.

ter Steege, H., Haripersaud, P. P., Bánki, O. S. \& F. Schieving. (2011). A model of botanical collectors' behavior in the field: Never the same species twice. American Journal of Botany, 98, 31-37.

Ule, E. (1901). Erster Bericht über den Verlauf der Kautschuk-Expedition bis zum Beginn des Jahres 1901. Notizblatt des Königl. botanischen Gartens und Museums zu Berlin, 3(26), 111-118.

Ule, E. (1904). Ules Expedition in das peruanische Gebiet des Amazonenstromes. Sechster Bericht über den Verlauf der Kautschuk-Expedition vom 21. Juni 1902 bis 23. Juni 1903. Notizblatt des Königlichen botanischen Gartens und Museums zu Berlin, 33(4), 114-123.

Ule, E. (1914). Bericht über den Verlauf der zweiten Expedition in das Gebiet des Amazonenstromes in den Jahren 1908 bis 1912. Notizblatt des Königlichen Botanischen Gartens und Museums zu Berlin-Dahlem, 6(53), 78-108.

Ule, E. (1914a). Die Vegetation des Roraima. Beiblatt zu den Botanischen Jahrbüchern, 52(1-2), 43.

Urban, I. (1906). Vitae Itineraque Collectorii Botanicorum, Notae Collaboratorum Biographicae, Florae Brasiliensis Ratio Edendi Chronologica, Systema, Index Familiarum. In: C. F. P. Martius, I. Urban \& A. Eichler, Flora Brasiliensis, fasciculus CXXX (ultimus) (1-268). Leipzig: Karl W. Hiersemann Publisher.

W. L. S. (1932). Obituary: Sir Everard im Thurn. The Geographical Journal, 80(6), 556-557.

Wolff, G. (ed). (2014). Geschichten von Bildern und Fotographen aus der Fotothek des Ibero-amerikanischen Instituts. Hamburg: Ibero amerikanisches Institut.

\section{OTHER BIBLIOGRAPHICAL REFERENCES}

Adam, T. (ed.) (2005). Germany and the Americas: culture, politics, and history. A Multidisciplinary Encyclopedia, Vol. I. Santa Barbara, California: ABC-CLIO.

Frahm, J. P. \& Eggers, J. (2001). Lexikon deutschprachiger Bryologen. Bod@libri.de.

Huber, O. \& Wurdack, J. J. (1984). History of Botanical Exploration in Territorio Federal Amazonas, Venezuela. Washington: Smithsonian Instituion Press.

Moschik, M. \& Weber-Unger, S. (2012). Reisen, so sagt man, ist eine Wissenschaft. Vienna: Wissenschaftliches Kabinett Weber-Unger.

Neumann, R. M. (2014). Colonizadora Meyer: impasses na compra e registro de propriedade da posse boi preto e colônia erval seco. Ágora, Santa Cruz do Sul, 16(1), 83-96.

Prance, G. T. (1971). An Index of Plant Collectors in Brazilian Amazonia. Acta Amazonica, 1(1), 25-65. 